\title{
Human Induced Pluripotent Stem-Cell-Derived Cardiomyocytes as Models for Genetic Cardiomyopathies
}

\author{
Andreas Brodehl 1,*®D, Hans Ebbinghaus ${ }^{1}$, Marcus-André Deutsch ${ }^{2}$, Jan Gummert ${ }^{1,2}$, \\ Anna Gärtner ${ }^{1}$, Sandra Ratnavadivel ${ }^{1}$ and Hendrik Milting ${ }^{1, *}$ \\ 1 Erich and Hanna Klessmann Institute, Heart and Diabetes Center NRW, University Hospital of the \\ Ruhr-University Bochum, Georgstrasse 11, D-32545 Bad Oeynhausen, Germany \\ 2 Department of Thoracic and Cardiovascular Surgery, Heart and Diabetes Center NRW, University Hospital \\ Ruhr-University Bochum, Georgstrasse 11, D-32545 Bad Oeynhausen, Germany \\ * Correspondence: abrodehl@hdz-nrw.de (A.B.); hmilting@hdz-nrw.de (H.M.); \\ Tel.: +49-(0)5731-973530 (A.B.); +49-(0)5731-973510 (H.M.)
}

Received: 29 July 2019; Accepted: 3 September 2019; Published: 6 September 2019

check for updates

\begin{abstract}
In the last few decades, many pathogenic or likely pathogenic genetic mutations in over hundred different genes have been described for non-ischemic, genetic cardiomyopathies. However, the functional knowledge about most of these mutations is still limited because the generation of adequate animal models is time-consuming and challenging. Therefore, human induced pluripotent stem cells (iPSCs) carrying specific cardiomyopathy-associated mutations are a promising alternative. Since the original discovery that pluripotency can be artificially induced by the expression of different transcription factors, various patient-specific-induced pluripotent stem cell lines have been generated to model non-ischemic, genetic cardiomyopathies in vitro. In this review, we describe the genetic landscape of non-ischemic, genetic cardiomyopathies and give an overview about different human iPSC lines, which have been developed for the disease modeling of inherited cardiomyopathies. We summarize different methods and protocols for the general differentiation of human iPSCs into cardiomyocytes. In addition, we describe methods and technologies to investigate functionally human iPSC-derived cardiomyocytes. Furthermore, we summarize novel genome editing approaches for the genetic manipulation of human iPSCs. This review provides an overview about the genetic landscape of inherited cardiomyopathies with a focus on iPSC technology, which might be of interest for clinicians and basic scientists interested in genetic cardiomyopathies.
\end{abstract}

Keywords: induced pluripotent stem cells; cardiomyopathies; cardiovascular genetics; cardiomyocytes; ARVC; DCM; HCM; RCM; NCCM; LVNC

\section{Introduction}

At the beginning of this century, the human genome project was finished [1]. The development of next generation sequencing (NGS) technologies significantly reduced the price and time, allowing for efficient genome and exome analyses, even in clinical routine procedures. However, even 20 years later, the clinical interpretation of genetic sequence variants (GSVs) is still challenging because the functional and structural impact of many variants is unknown. Therefore, multi-disciplinary approaches are often necessary for the interpretation and functional analysis of novel GSVs [2]. At present, in clinical routine procedures, the pathological impact of GSVs is classified due to standards and guidelines of the American College of Medical Genetics and Genomics (ACMG) [3].

Cardiomyopathies are diseases that affect the heart muscle, leading to functional and structural abnormalities [4], and are the main indication for heart transplantation (HTx) [5]. Beside environmental 
factors, like myocarditis or cardiotoxicity of cancer drugs, non-ischemic cardiomyopathies often have a genetic etiology with dominant inheritance. However, because pathogenic mutations in more than 100 different genes are associated with non-ischemic cardiomyopathies, the interpretation of novel GSVs is still challenging [6]. Moreover, little is currently known on digenic, or even polygenic, etiologies of cardiomyopathies [7]. Incomplete penetrance, different expressivity, and pleiotropy make the clinical interpretation even more challenging.

Functional analyses using adequate cell and animal models can lead to a more sophisticated interpretation of GSVs, which might be not only relevant for genetic counseling but also for the development of personalized therapies. According to the ACMG guidelines, in vitro or/and in vivo functional analyses provide strong criteria (PS3) for the classification of GSVs [3,8]. However, the generation of animal models is still time consuming and expensive. Moreover, in some cases, human cardiomyopathies cannot be modeled using animal models because of species differences. For example, TMEM43-p.S358L is a mutation with full penetrance in several families with arrhythmogenic cardiomyopathy (ACM) [9-11]. In contrast, the Tmem 43 knock-out, as well as the knock-in mice carrying this specific mutation, do not develop an ACM phenotype [12]. Because of these limitations, human iPSC-derived cardiomyocytes are unprecedented research tools to model and investigate genetic cardiomyopathies.

Here, we provide an overview about the genetic landscape of inherited cardiomyopathies and summarize the development of important human iPSC lines for modelling human cardiomyopathies in vitro. In addition, we review the differentiation into cardiomyocytes and discuss relevant methods used for the cellular and molecular characterization of human iPSC-derived cardiomyocytes.

\section{Clinical Background}

In clinical cardiology, cardiomyopathies are classified into five major structural subtypes (Figure 1). Dilated cardiomyopathy (DCM, MIM \#604145) is mainly characterized by left-ventricular dilation in combination with a decrease of the wall diameter [13]. These structural changes decrease the cardiac ejection fraction. Hypertrophic cardiomyopathy (HCM, MIM \#160760) is characterized by the hypertrophy of the ventricular walls and/or the septum [14], leading to a reduced cardiac output. Restrictive cardiomyopathy (RCM, MIM \#115210) is caused by an increase in ventricular stiffness, leading to dilated atria and diastolic dysfunction [15]. Hyper-trabeculation of the left ventricular wall is a hallmark for (left-ventricular) non-compaction cardiomyopathy (NCCM, MIM \#604169) [16]. It mainly affects the left ventricle, but isolated right ventricular or biventricular forms of NCCM have been reported [17]. Ventricular arrhythmias and predominant right or biventricular dilation are the main clinical symptoms of ACM (MIM \#609040) [18]. The fibro fatty replacement of the myocardial tissue is a pathognomonic feature characteristic of ACM [19]. However, at the early stage of the disease, structural changes may be absent or subtle [20]. Because ACM is a progressive disease, left ventricular involvement develops frequently at a later stage [21]. 


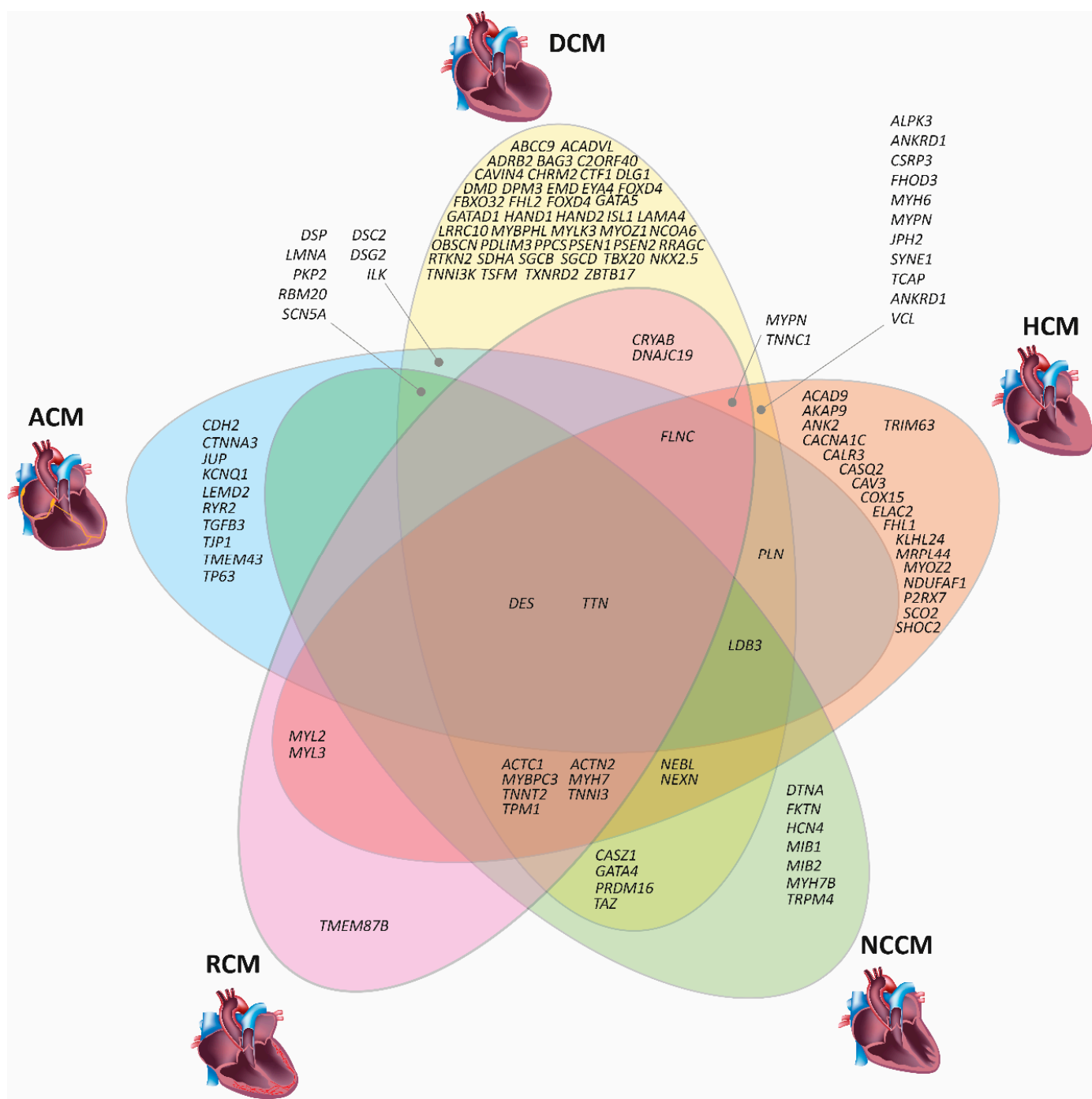

Figure 1. Schematic overview on cardiomyopathy associated genes and related clinical phenotypes. DCM-Dilated cardiomyopathy. HCM-Hypertrophic cardiomyopathy, ACM-Arrhythmogenic cardiomyopathy, NCCM-Non-compaction cardiomyopathy, RCM-Restrictive cardiomyopathy (Images of the DCM or HCM heart were licensed from shutterstock.com).

\section{Genetic Basis of Inherited Cardiomyopathies}

Thirty years ago, Seidmans' group discovered the first pathogenic mutation in $M Y H 7$, encoding for $\beta$-myosin heavy chain, in a four-generation family, in which several members developed HCM [22]. At present, genetic variants have been described in more than 100 different genes associated with non-ischemic cardiomyopathies or syndromes with cardiac involvement such as Marfan or Leopard syndrome (for an overview, see Table 1). Of note, the spectrum of affected genes and mutations partially overlaps between the different non-ischemic cardiomyopathies (Figure 1). For example, mutations in $D E S$, encoding the muscle specific intermediate filament protein desmin, might cause DCM [23,24], HCM [25], ACM [26,27], RCM [28], or NCCM [29-31]. Similarly, mutations in TTN, encoding the giant sarcomere protein titin, can also cause different types of structural, non-ischemic cardiomyopathies [32-34]. However, the molecular reasons why mutations in the same gene can cause different cardiac phenotypes are largely unknown.

From a genetic point of view, non-ischemic cardiomyopathies are quite heterogeneous [35-37]. However, the different non-ischemic cardiomyopathies are characterized by an accumulation of mutations in a distinct set of genes encoding for proteins that are essential for cardiomyocyte function. 
For example, HCM is mainly caused by mutations in genes encoding sarcomeric proteins such as $M Y H 7$ or MYBPC3 (Figure 1). Further mutations in other genes, encoding sarcomere proteins, like TPM1 [38], TNNC1 [39], TNNI3 [40], TNNT2 [38], FHL1 [41,42], or ACTC1 [43], have also been identified in patients with HCM (Table 1). In addition, in rare cases, mutations in genes encoding for Z-disc proteins, like ACTN2 [44] or FLNC [45], or genes encoding for proteins involved in the $\mathrm{Ca}^{2+}$-homeostasis like PLN [46], are also known to cause HCM (see Figure 1).

TTN is the most prevalent DCM-related gene with truncating TTN mutations identified in about $20-25 \%$ of DCM patients [32,47]. However, several other genes with a lower prevalence can also cause DCM. Besides, mutations have been identified in genes coding proteins of the sarcomere (e.g., MYH7 [48]), the cytoskeleton (e.g., DES [23,24]), the nuclear lamina (e.g., LMNA [49]), ion channels (e.g., SCN5A [50]), and transcription (e.g., EYA4 [51]) or splicing factors (e.g., RBM20 [52]) (Table 1). RBM20 mutations cause an aggressive early onset phenotype including arrhythmias, sudden cardiac death, and DCM, especially in males [53]. In total, mutations associated with DCM have been described in about 80 different genes (see Figure 1 and Table 1).

NCCM is the third most frequent non-ischemic cardiomyopathy [54,55] and can occur as a primary cardiomyopathy or can be part of a syndromic disease like the Barth syndrome (MIM,\#302060) [56]. Mutations in over 20 different genes having a significant overlap with HCM- or DCM-associated genes have been described in NCCM patients so far (see Figure 1 and Table 1). Comparable to HCM, the most prevalent NCCM-associated genes are MYH7 and MYBPC3 [57], which encode sarcomeric proteins (Table 1).

ACM is mainly caused by mutations in genes, encoding structural components of the cardiac desmosomes, and adherens junctions $[26,58,59]$. The cardiac desmosomes are cell-cell junctions mediating the adhesion of the cardiomyocytes [60]. In about $50 \%$ of the ACM patients, one or more mutations in desmosomal genes can be identified [26,59,61] (Table 1). Cardiac desmosomes are linked through the intermediate filaments formed mainly by desmin $(D E S)$ with several other cell organelles like the Z-bands or the nuclei. Of note, mutations in the DES gene can also cause ACM by abnormal cytoplasmic desmin aggregation [26,62]. In addition, mutations in genes of the nuclear envelope like LMNA [63], TMEM43 [9,10], or LEMD2 [64] are associated with ACM (Table 1). Furthermore, some rare mutations in non-desmosomal and non-nuclear genes like RYR2 [65,66], PLN [67], or ILK [68] have been identified in ACM patients.

Currently, the genetic etiology of RCM is poorly characterized. Recently, Kostareva et al. and Gallego-Delgado et al. genotyped two small cohorts of unrelated RCM index patients and identified likely pathogenic or pathogenic mutations in $50-75 \%$ of them $[69,70]$. The majority of affected RCM genes, which partially overlap with the group of HCM-associated genes, encode for sarcomere or cytoskeleton proteins (see Figure 1 and Table 1). The first RCM-associated mutation was identified in TNNI3, encoding cardiac troponin I [71]. More recently, there is growing evidence that FLNC mutations, encoding the cytolinker protein filamin-C, are frequently associated with RCM [72-76].

In summary, a relevant amount of all non-ischemic cardiomyopathies have a genetic etiology. Although in most cases, cardiomyopathies are inherited monogenetically, the underlying genetic landscape is complex, diverse, and currently only partially known. 
Table 1. Overview of cardiomyopathy associated genes carrying mutations.

\begin{tabular}{|c|c|c|c|c|c|c|c|}
\hline Gene & Protein & Function & HCM & DCM & NCCM & $\mathrm{ACM}$ & RCM \\
\hline$A B C C 9$ & ATP Binding Cassette Subfamily C Member 9 & $\mathrm{ABC}$ transporter & & [77] & & & \\
\hline ACAD9 & Acyl-CoA Dehydrogenase Member 9 & Dehydrogenase & [78] & & & & \\
\hline$A C A D V L$ & Acyl-CoA Dehydrogenase Very Long Chain & Dehydrogenase & & [79] & & & \\
\hline ACTC1 & Cardiac Actin & Sarcomere protein & {$[43,80]$} & [81] & [82] & & [83] \\
\hline ACTN2 & $\alpha$-Actinin 2 & Z-band protein & [84] & [85] & [86] & & [69] \\
\hline$A D R B 2$ & Adrenoreceptor $\beta 2$ & G-protein coupled receptor & & [87] & & & \\
\hline AKAP9 & A Kinase Anchoring Protein 9 & Scaffolding protein & [88] & & & & \\
\hline ALMS1 & Alstrom Syndrome Protein 1 & Microtubule organization & & {$[89]^{1}$} & & & \\
\hline ALPK3 & $\alpha$-Kinase 3 & Kinase & [90] & [90] & & & \\
\hline ANK2 & Ankyrin 2 & Cytoskeleton linker protein & [91] & & & [92] & \\
\hline ANKRD1 & Ankyrin Repeat Domain Containing Protein 1 & Transcription factor & [93] & {$[94,95]$} & & & \\
\hline BAG3 & Bcl-2 Associated Athanogene 3 & Co-chaperone & & [96] & & & {$[69,97]$} \\
\hline$B R A F$ & B-Raf Proto-Oncogene, Serine/Threonine Kinase & Kinase & {$[98]^{2}$} & & & & \\
\hline C2ORF40 & Chromosome 2 Open Reading Frame 40 & Hormone & & [99] & & & \\
\hline CACNA1C & Calcium Voltage-Gated Channel Subunit $\alpha 1 C$ & Calcium channel & [100] & & & & \\
\hline CALM3 & Calmodulin 3 & Calcium binding & {$[101]^{3}$} & & & & \\
\hline CALR3 & Calreticulin 3 & Calcium binding chaperone & [46] & & & & \\
\hline CASQ2 & Calsequestrin 2 & Calcium binding & [46] & & & & \\
\hline CASZ1 & Castor Zinc Finger 1 & Transcription factor & & [102] & [103] & & \\
\hline$C A V 3$ & Caveolin 3 & Scaffolding protein & [104] & & & & \\
\hline CAVIN4 & Muscle Restricted Coiled Coil Protein & Myofibrillar organization & & [105] & & & \\
\hline $\mathrm{CDH} 2$ & N-Cadherin & Cell-cell adhesion & & & & {$[106,107]$} & \\
\hline CHRM2 & Cholinergic Receptor Muscarinic 2 & G-protein coupled receptor & & [108] & & & \\
\hline COL3A1 & Collagen Type III Alpha 1 Chain & Extra cellular matrix protein & & & {$[109]^{4}$} & & \\
\hline COX15 & Cytochrome C Oxidase Assembly Homolog COX15 & Mitochondrial respiratory chain & [110] & & & & \\
\hline
\end{tabular}


Table 1. Cont

\begin{tabular}{|c|c|c|c|c|c|c|c|}
\hline Gene & Protein & Function & HCM & DCM & NCCM & $\mathrm{ACM}$ & RCM \\
\hline$C R Y A B$ & $\alpha \mathrm{B}-$ Crystallin & Chaperone-like activity & & [111] & & & [112] \\
\hline CSRP3 & Muscle LIM Protein & Scaffolding protein & [113-115] & [116] & & & \\
\hline CTF1 & Cardiotrophin 1 & Cytokine & & [117] & & & \\
\hline CTNNA3 & $\alpha \mathrm{T}-$ Catenin & Cell-cell adhesion & & & & [118] & \\
\hline DES & Desmin & Intermediate filament protein & [25] & {$[24,119]$} & [30] & [26] & [28] \\
\hline DLG1 & Discs Large MAGUK Scaffold Protein 1 & Scaffolding protein & & [88] & & & \\
\hline$D M D$ & Dystrophin & Dystrophin-glycoprotein complex & & [120] & & & \\
\hline DNAJC19 & DNAJ Heat Shock Protein Family C19 & Co-chaperone & & [121] & & & [121] \\
\hline DOLK & Dolichol Kinase & Phosphorylation of dolichol & & {$[122]^{5}$} & & & \\
\hline DPM3 & Dolichyl-Phosphate Mannosyltransferase Subunit 3 & Mannosyltransferase & & [123] & & & \\
\hline DSC2 & Desmocollin 2 & Cell-cell adhesion & & [35] & & [124] & \\
\hline DSG2 & Desmoglein 2 & Cell-cell adhesion & & [125] & & {$[126,127]$} & \\
\hline DSP & Desmoplakin & Cell-cell adhesion & & [128] & [129] & [130] & \\
\hline DTNA & $\alpha$-Dystrobrevin & Dystrophin-glycoprotein complex & & & [131] & & \\
\hline ELAC2 & ElaC Ribonuclease Z2 & $3^{\prime}$-tRNA endoribonuclease & [132] & & & & \\
\hline$E M D$ & Emerin & Nuclear lamina associated protein & & [133] & & & \\
\hline EYA4 & Eyes Absent Homolog 4 & Transcription factor & & [51] & & & \\
\hline FBN1 & Fibrillin 1 & Extra cellular matrix protein & {$[134]^{6}$} & {$[135]^{7}$} & {$[136]^{7}$} & & \\
\hline FBXO32 & F-Box Only Protein 32 & Ubiquitin-protein ligase complex & & {$[137,138]$} & & & \\
\hline FHL1 & Four and a Half LIM Domain Protein 1 & Scaffolding protein & [41] & & & & \\
\hline FHL2 & Four and a Half LIM Domain Protein 2 & Scaffolding protein & & [139] & & & \\
\hline FHOD3 & Formin Homology 2 Domain Containing Protein 3 & Organization of actin-polymerization & [140] & [141] & & & \\
\hline$F K R P$ & Fukutin Related Protein & $\begin{array}{l}\text { Posttranslational modification of } \\
\text { dystroglycan }\end{array}$ & & {$[142]^{8}$} & & & \\
\hline FKTN & Fukutin & Glycosyltransferase of dystroglycan & & & [143] & & \\
\hline FLNC & Filamin C & Cell junction organization & {$[45]$} & {$[144,145]$} & & [145] & [72] \\
\hline
\end{tabular}


Table 1. Cont.

\begin{tabular}{|c|c|c|c|c|c|c|c|}
\hline Gene & Protein & Function & HCM & DCM & NCCM & ACM & RCM \\
\hline FOXD4 & Forkhead Box Protein D4 & Transcription factor & & [146] & & & \\
\hline FXN & Frataxin & $\begin{array}{l}\text { Regulation of mitochondrial iron } \\
\text { transport }\end{array}$ & {$[147]^{9}$} & & & & \\
\hline$G A A$ & $\alpha$-Glucosidase & Glycogen metabolism & {$[148]^{9}$} & & & & \\
\hline GATA4 & GATA Binding Protein 4 & Transcription factor & & [149] & {$[150]^{10}$} & & \\
\hline GATA5 & GATA Binding Protein 5 & Transcription factor & & [151] & & & \\
\hline GATAD1 & GATA Zink Finger Domain Containing Protein 1 & Gene expression regulation & & [152] & & & \\
\hline GLA & Galactosidase $\alpha$ & Galactose metabolism & {$[153]^{11}$} & & & & \\
\hline GTPBP3 & GTP Binding Protein 3, Mitochondrial & Mitochondrial tRNA modification & {$[154]^{12}$} & & & & \\
\hline HAND1 & Heart and Neural Crest Derivatives Expressed 1 & Transcription factor & & [155] & & & \\
\hline HAND2 & Heart and Neural Crest Derivatives Expressed 2 & Transcription factor & & [156] & & & \\
\hline $\mathrm{HCN} 4$ & $\begin{array}{l}\text { Hyperpolarization Activated Cyclic Nucleotide } \\
\text { Gated Potassium Channel } 4\end{array}$ & Potassium channel & & & [157] & & \\
\hline HRAS & HRas Proto-Oncogene GTPase & Signaling protein & {$[158]^{13}$} & & & & \\
\hline$I L K$ & Integrin Linked Kinase & Scaffolding protein & & {$[159,160]$} & & [68] & \\
\hline ISL1 & ISL LIM Homeobox 1 & Transcription factor & & [161] & & & \\
\hline ITGA7 & Integrin Subunit A7 & Cell-cell and cell-matrix junction protein & & & {$[162]^{14}$} & & \\
\hline ITPA & Inosine Triphosphate Pyrophosphatase & Nucleotide metabolism & & {$[163]^{15}$} & & & \\
\hline JPH2 & Junctophilin 2 & Junctional complex & [164] & [165] & & & \\
\hline JUP & Plakoglobin & Cell-cell adhesion & & & & [58] & \\
\hline KCNQ1 & $\begin{array}{l}\text { Potassium Channel Voltage Gated KQT-Like } \\
\text { Subfamily Member } 1\end{array}$ & Potassium channel & & & & {$[166]$} & \\
\hline KLHL24 & Kelch Like 24 & Ubiquitin ligase substrate receptor & [167] & & & & \\
\hline LAMA4 & Laminin $\alpha 4$ & Extra cellular matrix protein & & [159] & & & \\
\hline LAMP2 & Lysosomal Associated Membrane Protein 2 & Chaperone-mediated autophagy & {$[168]^{16}$} & & & & \\
\hline$L D B 3$ & LIM Domain Binding Protein 3 & Z-band protein & [169] & {$[170,171]$} & {$[170,172]$} & [173] & \\
\hline
\end{tabular}


Table 1. Cont.

\begin{tabular}{|c|c|c|c|c|c|c|c|}
\hline Gene & Protein & Function & HCM & DCM & NCCM & $\mathrm{ACM}$ & RCM \\
\hline LEMD2 & LEM Domain Containing Protein 2 & Nuclear lamina associated protein & & & & $\begin{array}{c}{[64,174]} \\
17\end{array}$ & \\
\hline LMNA & Lamin A/C & Nuclear lamina associated protein & & [49] & [175] & [63] & \\
\hline LRRC10 & Leucine Rich Repeat Containing Protein 10 & Actin and $\alpha$-actinin binding protein & & [176] & & & \\
\hline MIB1 & Mindbomb Drosophila Homolog 1 & Ubiquitin ligase & & & [177] & & \\
\hline MIB2 & Mindbomb Drosophila Homolog 2 & Ubiquitin ligase & & & {$[178]^{18}$} & & \\
\hline MRPL3 & Mitochondrial Ribosomal Protein L3 & Mitochondrial ribosomal protein & {$[179]^{19}$} & & & & \\
\hline MRPL44 & Mitochondrial Ribosomal Protein L44 & Mitochondrial ribosomal protein & {$[180,181]$} & & & & \\
\hline MYBPC3 & Myosin Binding Protein C3 & Sarcomere protein & {$[182,183]$} & [184] & [185] & & [186] \\
\hline MYBPHL & Myosin Binding Protein H-Like & Sarcomere protein & & [187] & & & \\
\hline MYH6 & Myosin Heavy Chain 6 & Sarcomere protein & [188] & [188] & & & \\
\hline MYH7 & Myosin Heavy Chain 7 & Sarcomere protein & [22] & [48] & [7] & & [189] \\
\hline MYH7B & Myosin Heavy Chain 7B & Sarcomere protein & & & {$[162]^{20}$} & & \\
\hline MYL2 & Myosin Light Chain 2 & Sarcomere protein & [190] & & & & [191] \\
\hline$M Y L 3$ & Myosin Light Chain 3 & Sarcomere protein & [192] & & & & [192] \\
\hline MYLK3 & Myosin Light Chain Kinase 3 & Kinase & & [193] & & & \\
\hline MYOZ1 & Myozenin 1 & Calcineurin interacting protein & & [194] & & & \\
\hline MYOZ2 & Myozenin 2 & Calcineurin interacting protein & [195] & & & & \\
\hline$M Y P N$ & Myopalladin & Z-band protein & [196] & {$[94,197]$} & & & {$[196,198]$} \\
\hline NCOA6 & Nuclear Receptor Coactivator 6 & Gene expression regulation & & [199] & & & \\
\hline NDUFAF1 & $\begin{array}{l}\text { NADH: Ubiquinone Oxidoreductase Complex } \\
\text { Assembly Factor } 1\end{array}$ & Mitochondrial respiratory chain & [200] & & & & \\
\hline NDUFV2 & $\begin{array}{l}\text { NADH: Ubiquinone Oxidoreductase Core } \\
\text { Subunit V2 }\end{array}$ & Mitochondrial respiratory chain & {$[201,202]^{21}$} & & & & \\
\hline$N E B L$ & Nebulette & Z-band protein & [203] & [204] & [203] & & \\
\hline NEXN & Nexilin & Sarcomere protein & [205] & [206] & [207] & & \\
\hline
\end{tabular}


Table 1. Cont.

\begin{tabular}{|c|c|c|c|c|c|c|c|}
\hline Gene & Protein & Function & HCM & DCM & NCCM & ACM & RCM \\
\hline NKX2.5 & NK2 Homeobox 5 & Transcription factor & & [208] & & & \\
\hline OBSCN & Obscurin & Scaffolding protein & & [209] & & & \\
\hline$P 2 R X 7$ & Purinergic receptor P2X7 & ATP gated ion channel & [210] & & & & \\
\hline PDLIM3 & PDZ And LIM Domain 3 & Z-band protein & & [194] & & & \\
\hline PKP2 & Plakophilin 2 & Cell-cell adhesion & & [35] & [211] & [212] & \\
\hline$P L N$ & Phospholamban & Regulator of SERCA & [46] & {$[213,214]$} & & [67] & \\
\hline PPCS & Phosphopantothenoylcystein Synthetase & Co-enzyme A synthesis & & [215] & & & \\
\hline PRDM16 & PR Domain Containing Protein 16 & Transcription factor & & [216] & [217] & & \\
\hline PRKAG2 & Protein Kinase AMP Activated Non-catalytic G2 & Energy sensor kinase & {$[218,219]^{22}$} & & & & \\
\hline PSEN1 & Presenilin 1 & $\gamma$-Secretase & & {$[220,221]$} & & & \\
\hline PSEN2 & Presenilin 2 & $\gamma$-Secretase & & [220] & & & \\
\hline PTEN & Phosphatase and Tensin Homolog & Phosphatase & & & {$[150]^{23}$} & & \\
\hline PTPN11 & Protein Tyrosine Phosphatase Non-Receptor Type 1 & Phosphatase & {$[222]^{24}$} & & & & \\
\hline RAF1 & Raf-1 Proto-Oncogene, Serine/Threonine Kinase & Kinase & {$[223,224]^{25}$} & [225] & & & \\
\hline RBM20 & RNA Binding Protein 20 & Splicing factor & & {$[52,226]$} & [227] & {$[228,229]$} & \\
\hline RRAGC & Ras Related GTP Binding C & GTR/RAG GTP-binding protein & & [230] & & & \\
\hline RTKN2 & Rhotekin 2 & Scaffolding protein & & [99] & & & \\
\hline$R Y R 2$ & Ryanodine Receptor 2 & Calcium channel & & & & [66] & \\
\hline SCN5A & Sodium Channel Voltage Gated Type V Subunit A & Sodium channel & & {$[50,231]$} & & [232] & \\
\hline SCO2 & SCO2 Cytochrome C Oxidase Assembly Protein & Metallo-chaperone & [233] & & & & \\
\hline SDHA & Succinate Dehydrogenase Complex Subunit A & Mitochondrial respiratory chain & & [234] & & & \\
\hline$S G C B$ & Sarcoglycan $\beta$ & Dystrophin-glycoprotein complex & & [235] & & & \\
\hline SGCD & Sarcoglycan $\delta$ & Dystrophin-glycoprotein complex & & [236] & & & \\
\hline SHOC2 & Suppressor Of Clear, C. Elegans, Homolog & Scaffolding protein & [237] & & & & \\
\hline SYNE1 & Nesprin 1 & Component of the LINC complex & [238] & [239] & & & \\
\hline$T A Z$ & Tafazzin & Cardiolipin metabolism & & {$[240]^{26}$} & {$[241,242]$} & & \\
\hline
\end{tabular}


Table 1. Cont.

\begin{tabular}{|c|c|c|c|c|c|c|c|}
\hline Gene & Protein & Function & HCM & DCM & NCCM & $\mathrm{ACM}$ & RCM \\
\hline TBX20 & T-Box Factor 20 & Transcription factor & & {$[243,244]$} & & & \\
\hline TCAP & Thelethonin & Titin binding & [245] & {$[244,245]$} & & & \\
\hline TGFB3 & Transforming Growth Factor $\beta 3$ & Growth factor & & & & {$[246]$} & \\
\hline TJP1 & Zonula Occludens 1 & Tight junction adapter protein & & & & {$[247]$} & \\
\hline TMEM43 & Transmembrane Protein 43 & Nuclear lamina associated protein & & & & {$[9,10]$} & \\
\hline TMEM87B & Transmembrane Protein 87B & $\begin{array}{c}\text { Endosome-to-trans-Golgi retrograde } \\
\text { transport }\end{array}$ & & & & & [248] \\
\hline TNNC1 & Cardiac Troponin C & Sarcomere protein & [39] & [249] & & & [250] \\
\hline TNNI3 & Cardiac Troponin I & Sarcomere protein & [40] & [251] & [252] & & [71] \\
\hline TNNI3K & TNNI3 Interacting Kinase & Kinase & & [253] & & & \\
\hline TNNT2 & Cardiac Troponin T & Sarcomere protein & [38] & [254] & [255] & & [83] \\
\hline TP63 & Tumor Protein 63 & Transcription factor & & & & {$[256]$} & \\
\hline TPM1 & Tropomyosin 1 & Sarcomere protein & {$[38,257]$} & [258] & [259] & & [191] \\
\hline TRIM63 & Tripartite Motif Containing Protein 63 & Ubiquitin ligase & [260] & & & & \\
\hline TRPM4 & $\begin{array}{c}\text { Transient Receptor Potential Cation Channel } \\
\text { Subfamily M }\end{array}$ & Cation channel & & & [261] & & \\
\hline TSFM & Mitochondrial Translation Elongation Factor Ts & Translation elongation factor & & [262] & & & \\
\hline TTN & Titin & Sarcomere protein & [263] & {$[32,264]$} & {$[87,265]$} & [33] & [34] \\
\hline TTR & Transthyretin & Carrier protein & {$[266,267]^{27}$} & & & & \\
\hline TXNRD2 & Thioredoxin Reductase 2 & Reduces thioredoxins & & [268] & & & \\
\hline$V C L$ & Vinculin & Cell-cell and cell-matrix junction protein & {$[269,270]$} & [271] & & & \\
\hline ZBTB17 & Zinc Finger and BTB Domain Containing Protein 17 & Transcription factor & & {$[272,273]$} & & & \\
\hline
\end{tabular}

${ }^{1}$ Alström syndrome (MIM \#203800); ${ }^{2}$ Cardiofaciocutaneous syndrome (MIM \#115150); ${ }^{3}$ Modifier gene; ${ }^{4}$ Ehlers-Danlos syndrome (MIM \#130090); ${ }^{5}$ Multi-organ involvement; ${ }^{6}$ Digenetic

with PTPN11 mutations, combined with Marfan and Leopard syndrome: ${ }^{7}$ Marfan Syndrome (MIM \#154700); ${ }^{8}$ Limb-girdle muscular dystrophy; ${ }^{9}$ Friedreich ataxia (MIM \#229300);

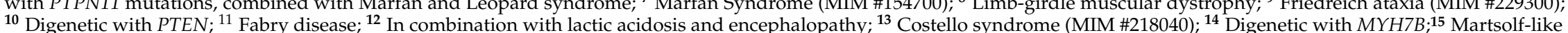
${ }^{10}$ Digenetic with PTEN; ${ }^{11}$ Fabry disease; ${ }^{12}$ In combination with lactic acidosis and encephalopathy; ${ }^{13}$ Costello syndrome (MIM \#218040); ${ }^{14}$ Digenetic with $M Y H 7 B ;{ }^{15}$ Martsolf-like
syndrome (MIM \#212720) in combination with DCM; ${ }^{16}$ Danon disease (MIM \#300257); ${ }^{17}$ In combination with cataract; ${ }^{18}$ In combination with giant hypertrophic gastritis (MIM \#137280, Ménétrier disease); ${ }^{18}$ In combination with psychomotor retardation; ${ }^{19}$ Digenetic with ITGA7; ${ }^{20}$ In combination with encephalopathy; ${ }^{21}$ Wolff-Parkinson-White syndrome (MIM \#194200); ${ }^{22}$ Digenetic with GATA4 mutation; ${ }^{23}$ Noonan syndrome; ${ }^{24}$ Noonan syndrome or Leopard syndrome; ${ }^{25}$ Barth syndrome (MIM \#302060); ${ }^{26}$ Amyloid cardiomyopathy (MIM \#105210); ${ }^{27}$ Fabry disease. 


\section{Generation of Patient-Specific-Induced Pluripotent Stem Cells Via Reprogramming}

In the 1960s, Gurdon et al. cloned Xenopus laevis for the first time [274,275]. Consequently, Gurdon was awarded the Nobel Prize in medicine in 2012, together with Yamanaka [276]. The cloning of mammals by nuclear transfer from somatic cells into enucleated unfertilized mammalian eggs over twenty years ago demonstrated that the cellular differentiation can be artificially turned back into a pluripotent state [277]. The next breakthrough was the identification of essential reprogramming factors by the Yamanaka group [278,279]. Initially, reprogramming was performed with 24 candidate transcription factor genes. Out of these, four critical genes were identified to be crucial for iPSC generation: Sox2, Oct4, Klf4, and c-Myc [278]. Depending on the donor cell type, the set of reprogramming factors can vary since specific cell types might endogenously express some of the necessary factors. For example, $c-M y c$ is not required for the reprogramming of fibroblasts [280].

Different delivery methods were developed for reprogramming of somatic cell types like fibroblasts, lymphocytes, keratinocytes, urine-derived, or intestinal cells into iPSCs (see Figure 2). Initially, iPSCs were generated using retroviral transduction [278,279,281]. The Moloney-based retroviral vector system used by the Yamanaka lab has the advantage of undergoing silencing in the iPSCs state but is restricted to dividing cell types. Therefore, lentiviruses were used to improve the transduction efficiency of dividing and non-dividing cell types. However, after lentiviral transduction, the expression of the reprogramming factors are poorly silenced [282,283], leading to difficult differentiation of these iPSCs [284]. Therefore, inducible systems were used, allowing for the silencing of the Yamanaka factors in iPSCs [284,285].

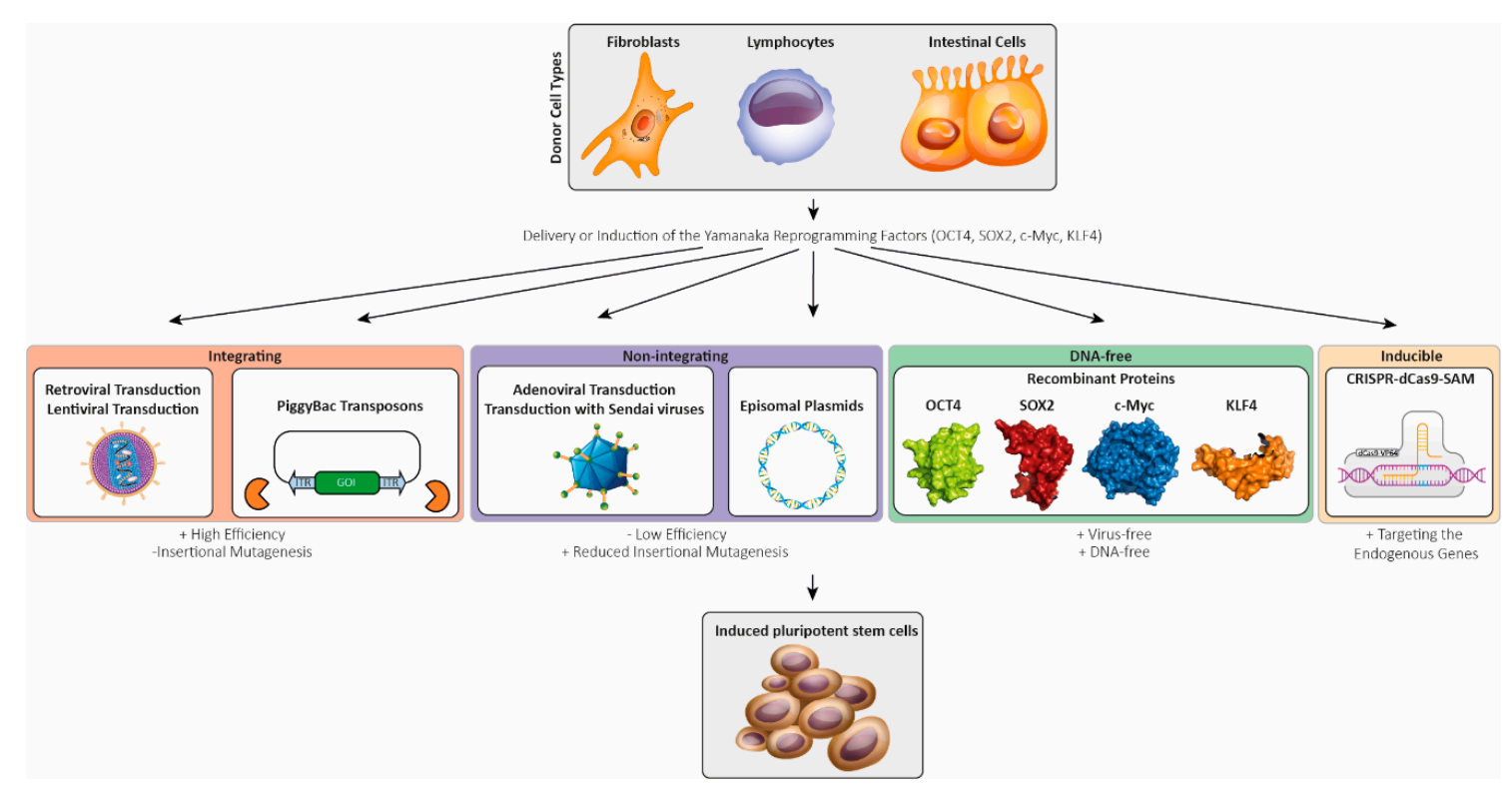

Figure 2. Schematic overview about different delivery methods of the Yamanaka factors into somatic primary cells for reprogramming (sub-figures for the cell types and viruses were licensed from shutterstock.com).

However, usage of integrating viral systems enhances the risk for insertional mutagenesis, limiting their application [286]. Furthermore, the transgene reactivation of c-Myc showed increased tumorigenicity in chimeric mice [280], limiting the usage of iPSCs for clinical approaches. To overcome these limitations, non-integrating delivery methods have been developed. Transient transfection of the PiggyBac transposon with a Cre-mediated excisable system was one of the first non-integrating methods (Figure 2). Minimized genome modification, in combination with silencing of the reprogramming factor expression in the iPSC state, are the main advantages of this system [287]. Another approach is the adenoviral transduction leading to an overexpression of the reprogramming factors in the host cells without genomic integration [288]. Transient transfection or electroporation with episomal plasmids 
encoding the reprogramming factors is an alternative method to produce virus-free iPSCs [289] (Figure 2). However, the efficiency of this delivery method is quite low [290]. More promising non-inserting delivery methods include the use of Sendai viruses [291], which are RNA viruses that do not enter the nucleus, thereby decreasing the risk of genomic insertion.

Reprogramming using miRNAs that are specifically expressed in embryonic pluripotent stem cells (ESCs) can enhance the reprogramming efficiency [292]. For example, the miR302/367 cluster is highly expressed in pluripotent cells, but not in differentiated cells, and its promoter is transcriptionally regulated by the reprogramming factors Oct4 and Sox2 [293]. This cluster is functionally involved in regulation of the cell cycle and maintenance of pluripotency. Overexpression of the miRNA cluster miR302/367 can promote the reprogramming of somatic cells [294]. In combination with the reprogramming factors, a higher efficiency can be achieved [292]. Although RNA-based reprogramming methods show higher efficiency compared to Sendai virus and episomal methods, the reliability is significantly lower [295]. Non-integrating delivery methods provide iPSCs that are more applicable for clinical disease modeling. Besides the integrating and non-integrating delivery systems, DNA-free approaches with transgene free reprogramming have been established. Small compounds or recombinant reprogramming factors were used (Figure 2) [296,297]. For example, the histone deacetylase inhibitor valproic acid improves the reprogramming efficiency [298,299]. The efficient synthesis of large amounts of purified native recombinant proteins and the permeabilization of the plasma membranes are crucial for this reprogramming method [300]. More recently, the CRISPR-dCas9-based synergistic activation mediator (SAM) system has been developed and applied for reprogramming [301,302]. This system is based on a fusion protein of the enzymatic inactive form of Cas9 (dCas9) and a transcription activator domain forming an artificial transcription factor which, in combination with specific guide RNAs, is able to activate the transcription of endogenous genes with minimal off-target activity. Weltner et al. successfully used this system for the expression of different reprogramming factors to generate iPSCs [302].

In summary, different integrating and non-integrating approaches have been developed for reprogramming different cell types into iPSCs to improve the efficiency and to reduce the risk of further genomic alterations (see Figure 2).

\section{Genetic Modification of Induced Pluripotent Stem Cell Lines}

Besides the generation of human iPSCs from the primary cells of mutation carriers by direct reprogramming $[278,281]$, specific genetic mutations can also be inserted using genome editing techniques like clustered regularly interspaced short palindromic repeats associated protein 9 (CRISPR-Cas9) [303], CPF1 [304], or transcription activator-like effector nucleases (TALENs) [305,306]. In addition to genome editing approaches, iPSCs or the differentiated cardiomyocytes can be genetically modified by overexpressing specific mutant proteins $[307,308]$ or by decreasing the expression of specific mutant proteins, e.g., by RNA interference [309].

Using patient-derived iPSCs, it is sometimes challenging to correlate directly functional effects in vitro with the specific genetic variants because the genetic and epigenetic background of the cells is largely unknown [310]. In contrast to patient-derived iPSCs, which carry the sum of all genetic sequence variants of the affected patients, genome edited iPSC lines carry specifically inserted mutations. Therefore, the effects of particular mutations can be directly compared with their corresponding isogenic wild-type controls in genome-edited iPSCs.

Genome editing techniques like CRISPR-Cas9 are based on endonuclease activity, which insert double-strand breaks (DSBs) into the DNA double helix at specific sites. Different endogenous cellular repair mechanisms like non-homologous end joining (NHEJ) or homology directed repair (HDR) are used for the repair of these DSBs. However, NHEJ is an imprecise process, which might lead to the insertion, deletion, or substitution of nucleotides [311]. Indel variants frequently cause frameshifts, and consequently, premature termination codons (PTCs). PTCs are recognized by nonsense mediated RNA decay (NMD) degrading the mutant mRNA. Therefore, DSBs can be efficiently used to 
generate knock-out models. In contrast, HDR uses DNA template molecules for the specific repair of the DSBs. In combination with suitable donor molecules, e.g., single-stranded oligonucleotides or double-stranded DNA templates like PCR products or plasmids, HDR can be used to insert specific point mutations [312], small peptide-encoding tags [313], or even larger fluorescence proteins at specific positions [314-316]. Unfortunately, the ratio of HDR to NHEJ is low, limiting the efficiency of knock-in strategies [317]. Therefore, different approaches for inhibiting NHEJ or promoting HDR have been developed (for reviews, see References [317-319]). The delivery of donor template molecules in close proximity to the DSBs by coupling Cas9 with the donor molecule might be a promising strategy [320-322]. An alternative are dCas9-related base pair editors [323-325], which can be used to exchange relevant nucleotides at specific positions.

\section{Differentiation of Human Induced Pluripotent Stem Cells into Cardiomyocytes}

The human adult heart is a post-mitotic organ with a very limited capacity for regeneration [326]. Beside the murine, atrial cardiomyocytes-related HL-1 cell line [327], no further contracting human cardiomyocytes cell lines are therefore currently available. Because of ethical and technical issues, the isolation of primary human cardiomyocytes from human surgical material and their long-time culture is in most cases impossible. Primary cardiomyocytes isolated from rodent hearts have characteristic differences like a different electrophysiology in comparison to the human ones. Therefore, cardiomyocytes derived from human ESCs or iPSCs are the predominant human cell resource [328,329].

Originally, Zhang et al. described the differentiation of cardiomyocytes from human iPSCs [330]. Comparable to ESCs, human iPSCs form embryonic bodies in suspension that can be further differentiated into cardiomyocytes [330-334]. However, the efficiency of this process was limited. In addition, monolayers of iPSC-derived cardiomyocytes can be generated [335,336]. In vivo, cardiogenesis is a complex cellular and molecular process where different transcription factors, growth factors, and miRNAs are time dependently expressed and regulated [337-341]. Driven by discoveries from development biology, it has been recognized that different recombinant growth factors, e.g., BMP4, can also be used to increase the efficiency of in vitro differentiation into cardiomyocytes [342-344]. In addition, modulation of the Wnt pathway by small molecules, e.g., CHIR99021 and IWP2, efficiently increases the differentiation into cardiomyocytes about $90 \%[344,345]$. Furthermore, metabolic selection by glucose depletion, in combination with lactate supplementation, can be applied for further accumulation of cardiomyocytes [346,347]. Recently, Zhao et al. developed a method for the differentiation and generation of heteropolar cardiac tissue with atrial and ventricular ends [348]. Talkhabi et al. has previously reviewed the differentiation of iPSCs into cardiomyocytes in detail [349].

\section{Methods for the Functional Analysis of Cardiomyocytes Derived from Induced Pluripotent Stem Cells}

Besides general histochemical or molecular methods, e.g., RNA-Seq or proteomics, specific techniques for the functional in vitro analysis of the electrophysiological and contractile properties of iPSC-derived cardiomyocytes are frequently used. Patch clamping and multiple electron arrays (MEAs) are frequently used for the electrophysiological analysis of iPSC-derived cardiomyocyte monolayers [350,351]. The application of $\mathrm{Ca}^{2+}$ specific fluorescence dyes, e.g., Indo1 or Fura-2, allows for the microscopic analysis of $\mathrm{Ca}^{2+}$ transients [352-354]. Additionally, voltage-sensitive fluorescence dyes like di-4-ANEPPS can be used for the analysis of the electrophysiological properties [355]. For the analysis of the contractile properties of iPSC-derived cardiomyocytes, microscopic techniques like traction force measurements have also been used [356]. Atomic force microscopy can also be applied for measuring the contraction forces of iPSC-derived cardiomyocytes [357,358]. Feaster and coworkers developed a method to culture iPSC-derived cardiomyocytes on Matrigel mattresses, allowing for the contractility measurement by cell shortening [359]. 


\section{Overview about Existing iPSC Lines Carrying Cardiomyopathy Associated Mutations}

In 2010, Carvajal-Vergara and co-workers published a landmark paper about the generation of an iPSC line carrying the heterozygous mutation PTPN11-p.T468M [360]. Mutations in PTPN11 cause the Leopard syndrome [361,362], which is frequently associated with severe HCM [363]. Interestingly, these iPSC-derived cardiomyocytes were larger and presented an abnormal, nuclear localization of NFATc4 [360]. Members of the NFAT family are involved in the calcineurin-NFAT signaling regulating hypertrophy [364]. Since this original report, about 70 different iPSC lines carrying cardiomyopathy-associated mutations in several different genes have been generated (Table 2). The majority of these mutant iPSC lines have been used for phenotypic modeling of genetic cardiomyopathies using electrophysiological and/or contraction measurements (Table 2). Besides modeling genetic cardiomyopathies, iPSC-derived cardiomyocytes were also used for the modeling of non-genetic causes of cardiomyopathies, e.g., doxorubicin cardiotoxicity [263,365], hypoxia [366], peripartum [367], or diabetic cardiomyopathy [368-371], or even infection with Trypanosoma cruzi [372] or with coxsackievirus B3 [373].

In the beginning, iPSC lines generated from healthy probands were frequently used as controls for experiments. However, because different iPSC lines have a variable genetic background, this approach has limitations. Since the development of efficient genome editing technologies like CRISPR-Cas9 or TALENs [303], it is common to generate isogenic control lines [374]. Interestingly, the reverse approach by inserting specific mutations in iPSCs from healthy control persons is also sometimes used [375]. In some cases, the rationale of these studies is the functional characterization of specific cardiomyopathy-associated mutations, which might contribute to a pathogenicity classification. In addition, iPSC-derived cardiomyocytes were used for the development of therapeutic strategies, e.g., genome editing. An interesting application of iPSC-derived cardiomyocytes is the testing of specific gene therapeutic concepts [376]. For example, Gramlich et al. applied antisense-mediated exon skipping in iPSC-derived cardiomyocytes with a truncating TTN (TTNtv) mutation for restoring the expression of titin [377]. However, at present, it appears that some of the TTNtv do not lead to premature translation termination in failing human hearts [378]. Thus, iPSCs might therefore be useful in future to check and modulate possible read-throughs of TTNtv mutations as well. Similarly, Kyrychenko et al. used CRISPR-Cas9 to delete whole exons within the DMD gene to correct the reading frame [379]. Of note, this strategy restores contractility in the iPSC-derived cardiomyocytes [379]. Hopefully, the combination of iPSC-derived cardiomyocytes with adequate modern genetic engineering tools will contribute in future to the development of therapeutic options in the context of personalized medicine. 
Table 2. Overview about important iPSC lines carrying mutations in genes associated with genetic cardiomyopathies or related diseases.

\begin{tabular}{|c|c|c|c|c|c|c|}
\hline Gene & Protein & Mutation(s) & Method of Generation & Main Phenotypic Findings & $\begin{array}{l}\text { Associated } \\
\text { Disease }\end{array}$ & References \\
\hline ACTC1 & Cardiac Actin & p.E99K & $\begin{array}{ll}- & \text { Sendai virus transduction } \\
\text { - } & \text { Isogenic controls using } \\
& \text { CRISPR-Cas9 (PiggyBac) }\end{array}$ & Arrhythmias & HCM/LVNC & [380] \\
\hline ALPK3 & $\alpha$-Kinase 3 & p.W1264Xhom & $\begin{array}{l}\text { Electroporation with episomal } \\
\text { plasmids }\end{array}$ & $\begin{array}{l}\text { - } \quad \text { Sarcomeric disarray } \\
\text { - } \quad \mathrm{Ca}^{2+} \text { handling defects }\end{array}$ & $\mathrm{HCM}$ & [381] \\
\hline$B A G 3$ & $\begin{array}{l}\text { Bcl-2 Associated } \\
\text { Athanogene } 3\end{array}$ & $\begin{array}{ll}- & \text { p.R90X } \\
\text { - } & \text { p.R90Xhom } \\
\text { - } & \text { p.R123X }\end{array}$ & $\begin{array}{ll}\text { - } & \text { Electroporation with } \\
\text { episomal plasmids } \\
\text { - } & \text { \& genome editing using } \\
\text { - } & \text { CRISPR-Cas9 } \\
\text { - } & \text { TALENs }\end{array}$ & $\begin{array}{ll}\text { - } & \text { Decreased BAG3 expression } \\
\text { - } & \text { Sarcomeric disarray after } \\
\text { prolonged culture } \\
\text { - } & \text { Decreased contraction }\end{array}$ & DCM & [374] \\
\hline$B R A F$ & $\begin{array}{l}\text { B-Raf Proto-Oncogene, } \\
\text { Serine/Threonine Kinase }\end{array}$ & $\begin{array}{ll}\text { - } & \text { p.Q257R } \\
\text { - } & \text { p.T599R }\end{array}$ & $\begin{array}{ll}\text { - } & \text { Retroviral transduction } \\
\text { Electroporation with } \\
\text { episomal plasmids }\end{array}$ & $\begin{array}{ll}\text { - } & \text { Cellular hypertrophy } \\
\text { - } & \text { Pro-hypertrophic gene expression } \\
\text { - } & \mathrm{Ca}^{2+} \text { handling defects } \\
\text { - } & \text { Abnormal TGF } \beta \text { signaling }\end{array}$ & CFCS/HCM & [382] \\
\hline$C A V$ & Caveolin & $\begin{array}{ll}- & \text { c. } 303 G>C \\
- & \text { c. } 233 C>A \\
- & \text { c. } \Delta 184-192\end{array}$ & $\begin{array}{l}\text { Electroporation with episomal } \\
\text { plasmids }\end{array}$ & NA & MP & [383] \\
\hline$C R Y A B$ & $\alpha \mathrm{B}-$ Crystallin & $\begin{array}{l}\text { - } \quad \text { c.343delT }{ }^{\text {het }} \\
\text { - } \quad \text { c.343delThom }\end{array}$ & $\begin{array}{l}\text { Retroviral transduction and } \\
\text { genome editing (zinc finger } \\
\text { nucleases) }\end{array}$ & $\begin{array}{l}\text { - } \\
\text { mutant } \alpha \mathrm{B}-\text { Crystallin } \\
\text { - } \quad \text { Loss of function mechanism }\end{array}$ & MFM & [384] \\
\hline$D E S$ & Desmin & p.N116S & Lentiviral transduction & NA & $\mathrm{ACM}$ & [385] \\
\hline$D E S$ & Desmin & c. $735+1 G>A$ & Sendai virus transduction & NA & DRC & [386] \\
\hline$D E S$ & Desmin & p.A285V & Retroviral transduction & $\begin{array}{ll}\text { - } & \text { Desmin aggregation } \\
\text { - } & \text { Z-disk streaming } \\
\text { - } & \text { Decreased spontaneous } \\
\text { beating rate }\end{array}$ & DCM & [387] \\
\hline$D M D$ & Dystrophin & $\begin{array}{ll}\text { - } & \Delta \mathrm{Ex} 8-12 \\
\text { - } & \mathrm{c} .5899 \mathrm{C}>\mathrm{T}\end{array}$ & Sendai virus transduction & $\begin{array}{ll}\text { - } & \text { Electrophysiological alterations } \\
\text { - } & \text { Arrhythmias } \\
\text { - } & \text { Prolonged action potential }\end{array}$ & DMD & [388] \\
\hline
\end{tabular}


Table 2. Cont

\begin{tabular}{|c|c|c|c|c|c|c|}
\hline Gene & Protein & Mutation(s) & Method of Generation & Main Phenotypic Findings & $\begin{array}{l}\text { Associated } \\
\text { Disease }\end{array}$ & References \\
\hline$D M D$ & Dystrophin & $\begin{array}{ll}\text { - } & \Delta \mathrm{Ex} 8-9 \\
\text { - } & \Delta \mathrm{Ex6-9} \\
\text { - } & \Delta \mathrm{Ex7-11} \\
\mathrm{E} \times 3-9\end{array}$ & $\begin{array}{l}\text { Sendai virus transduction in } \\
\text { combination with } \\
\text { CRISPR-Cas9 }\end{array}$ & $\begin{array}{l}\text { Out of frame deletion } \Delta \mathrm{Ex} 8-9 \\
\text { reduce contraction force } \\
\text { Second deletions to correct the } \\
\text { reading fame of DMD restores } \\
\text { the contractility }\end{array}$ & DMD & [379] \\
\hline$D M D$ & Dystrophin & $\begin{array}{ll}- & \text { c.263delG } \\
\text { - } & \Delta \mathrm{Ex} 50\end{array}$ & $\begin{array}{l}\text { Lentiviral transduction } \\
\text { CRISPR-Cas9 }\end{array}$ & $\begin{array}{ll}\text { - } & \text { Reduced contractility } \\
\text { - } & \mathrm{Ca}^{2+} \text { handling defects }\end{array}$ & DMD & {$[389,390]$} \\
\hline DSG2 & Desmoglein-2 & p.G638R & Sendai virus transduction & $\begin{array}{ll}\text { - } & \text { Electrophysiological alterations } \\
\text { - } & \text { Ion channel dysfunction }\end{array}$ & $\mathrm{ACM}$ & [391] \\
\hline$D S P$ & Desmoplakin & p.R451G & $\begin{array}{l}\text { Sendai virus transduction \& } \\
\text { genome editing for correction } \\
\text { (CRISPR-Cas9) }\end{array}$ & Reduced desmoplakin expression & $\mathrm{ACM}$ & [392] \\
\hline FBN1 & Fibrillin 1 & c. $4028 \mathrm{G}>\mathrm{A}$ & Sendai virus transduction & NA & $\begin{array}{l}\text { Marfan } \\
\text { Syndrome } \\
(\mathrm{HCM})\end{array}$ & [393] \\
\hline$F K R P$ & Fukutin Related Protein & c. $826 \mathrm{C}>\mathrm{A}^{\text {hom }}$ & Lentiviral transduction & $\begin{array}{ll}\text { - } & \text { Abnormal action potential } \\
\text { - } & \text { Electrophysiological alterations } \\
\text { - } & \text { Decreased expression of } S C N 5 A \\
& \text { and CACNA1C }\end{array}$ & $\begin{array}{l}\text { Limb-Girdle } \\
\text { Muscular } \\
\text { Dystrophy } \\
\text { (DCM) }\end{array}$ & [394] \\
\hline$F X N$ & Frataxin & Expanded GAA repeats & Retroviral transduction & $\begin{array}{ll}\text { - } & \text { Iron homeostasis defects } \\
\text { - } & \text { Disorganized mitochondria } \\
\text { - } & \text { Cellular hypertrophy } \\
\text { - } & \text { Increased BNP expression } \\
\text { - } & \mathrm{Ca}^{2+} \text { handling defects }\end{array}$ & $\begin{array}{l}\text { Friedreich } \\
\text { Ataxia } \\
\text { (HCM) }\end{array}$ & [395] \\
\hline$F X N$ & Frataxin & $\begin{array}{l}\text { Expanded GAA repeats } \\
\text { - } \quad 800 / 600 \\
\text { - } \quad 900 / 400\end{array}$ & Lentiviral transduction & $\begin{array}{ll}\text { - } & \text { Impaired mitochondrial function } \\
\text { - } & \text { Decreased mitochondrial } \\
\text { - } & \text { Dembrane potential } \\
& \text { Degeration of mitochondria }\end{array}$ & $\begin{array}{l}\text { Friedreich } \\
\text { Ataxia } \\
\text { (HCM) }\end{array}$ & [396] \\
\hline GLA & Galactosidase $\alpha$ & IVS4+919G > A & Retroviral transduction & $\begin{array}{ll}\text { - } & \text { Decreased } \alpha \text {-galactosidase activity } \\
\text { - } & \text { Cellular hypertrophy } \\
\text { - } & \text { Upregulation of fibrotic genes }\end{array}$ & $\begin{array}{l}\text { Fabry Disease } \\
\quad(\mathrm{HCM})\end{array}$ & {$[397,398]$} \\
\hline
\end{tabular}


Table 2. Cont

\begin{tabular}{|c|c|c|c|c|c|c|}
\hline Gene & Protein & Mutation(s) & Method of Generation & Main Phenotypic Findings & $\begin{array}{l}\text { Associated } \\
\text { Disease }\end{array}$ & References \\
\hline$L A M P 2$ & $\begin{array}{c}\text { Lysosomal Associated } \\
\text { Membrane Protein } 2\end{array}$ & IVS6+1_4delGTGA & Sendai virus transduction & Autophagy dysfunction & $\begin{array}{c}\text { Danon } \\
\text { Disease }(\mathrm{CM})\end{array}$ & [399] \\
\hline$L A M P 2$ & $\begin{array}{c}\text { Lysosomal Associated } \\
\text { Membrane Protein } 2\end{array}$ & $\begin{array}{ll}\text { - } & \text { c.129-130insAT } \\
\text { - } & \text { IVS-1.c64+1G > A }\end{array}$ & Unknown & $\begin{array}{ll}\text { - } & \text { Mitochondrial-oxidative stress } \\
\text { - } & \text { Apoptosis } \\
\text { - } & \text { Disrupted mitophagic flux } \\
& \text { Mitochondrial } \\
& \text { respiratory deficiency }\end{array}$ & $\begin{array}{c}\text { Danon } \\
\text { Disease }(\mathrm{CM})\end{array}$ & [400] \\
\hline$L A M P 2$ & $\begin{array}{l}\text { Lysosomal Associated } \\
\text { Membrane Protein } 2\end{array}$ & $\begin{array}{ll}\text { - } & \text { c.1082delA } \\
\text { - } & \text { c. } 247 \mathrm{C}>\mathrm{T} \\
\text { - } & \text { c. } 64+1 \mathrm{G}>\mathrm{A}\end{array}$ & $\begin{array}{ll}- & \text { Retroviral transduction } \\
- & \text { Sendai virus transduction } \\
\text { - } & \text { CRISPR-Cas9 } \\
& \text { for correction }\end{array}$ & $\begin{array}{ll}\text { - } & \text { Defects in autophagic fusion } \\
\text { - } & \text { Mitochondrial abnormalities } \\
\text { Contractile abnormalities }\end{array}$ & $\begin{array}{c}\text { Danon } \\
\text { Disease }(\mathrm{CM})\end{array}$ & [401] \\
\hline LMNA & Lamin $\mathrm{A} / \mathrm{C}$ & p.S143P & Sendai virus transduction & $\begin{array}{ll}\text { - } & \text { Sarcomere damage after hypoxia } \\
\text { - } & \text { Arrhythmias after } \\
\text { - } & \quad \mathrm{Ca}^{2+} \text { handrenergic stimulation } \\
\end{array}$ & DCM & [402] \\
\hline LMNA & Lamin $\mathrm{A} / \mathrm{C}$ & p.S18fsX & $\begin{array}{l}\text { Combined lentiviral and } \\
\text { retroviral transduction }\end{array}$ & Normal nuclear membrane morphology & DCM & [403] \\
\hline LMNA & Lamin $\mathrm{A} / \mathrm{C}$ & p.R225X & Lentiviral transduction & $\begin{array}{ll}- & \text { Reduced expression of lamin } \mathrm{A} / \mathrm{C} \\
\text { - Increased cellular apoptosis under } \\
\text { electrical stimulation }\end{array}$ & $\mathrm{DCM}$ & [404] \\
\hline LMNA & Lamin $\mathrm{A} / \mathrm{C}$ & $\begin{array}{ll}\text { - } & \text { p.R225X } \\
\text { - } & \text { p.Q354X } \\
\text { - } & \text { p.T518fsX29 }\end{array}$ & Lentiviral transduction & $\begin{array}{ll}\text { - } & \text { Increased nuclear blebbing under } \\
\text { electrical stimulation } \\
\text { - } \quad \text { Increased apoptosis under } \\
\text { electrical stimulation } \\
\text { - } \quad \text { Haploinsufficiency } \\
\text { - Treatment with PTC124 reverse the } \\
\text { phenotypic findings }\end{array}$ & $\begin{array}{l}\text { DCM \& } \\
\text { conduction } \\
\text { disorders }\end{array}$ & [405] \\
\hline LMNA & Lamin $\mathrm{A} / \mathrm{C}$ & p.K219T & Lentiviral transduction & $\begin{array}{ll}\text { - } & \text { Electrophysiological alterations } \\
\text { Downregulation of } S C N 5 A \\
\text { expression by epigenetic } \\
\text { modulation of the promoter }\end{array}$ & $\begin{array}{l}\text { DCM \& } \\
\text { conduction } \\
\text { disorders }\end{array}$ & [406] \\
\hline
\end{tabular}


Table 2. Cont.

\begin{tabular}{|c|c|c|c|c|c|c|}
\hline Gene & Protein & Mutation(s) & Method of Generation & Main Phenotypic Findings & $\begin{array}{l}\text { Associated } \\
\text { Disease }\end{array}$ & References \\
\hline MT-RNR2 & $\begin{array}{c}\text { Mitochondrially Encoded } \\
\text { 16S rRNA }\end{array}$ & $\mathrm{m} .2336 \mathrm{~T}>\mathrm{C}$ & Retroviral transduction & $\begin{array}{ll}\text { - } & \text { Decreased stability of } 16 \mathrm{~S} \text { rRNA } \\
\text { - } & \text { Mitochondrial dysfunction } \\
\text { - } & \text { Reduced ATP/ADP ratio } \\
\text { - } & \text { Reduced mitochondrial potential } \\
\text { - } & \text { Electrophysiological alterations }\end{array}$ & $\mathrm{HCM}$ & [407] \\
\hline MYBPC3 & $\begin{array}{l}\text { Myosin Binding } \\
\text { Protein C3 }\end{array}$ & $\begin{array}{ll}- & \text { p.V321M } \\
\text { - } & \text { p.V219L } \\
\text { - } & \text { c.2905+1G > A }\end{array}$ & Sendai virus transduction & Abnormal $\mathrm{Ca}^{2+}$ handling & $\mathrm{HCM}$ & [408] \\
\hline MYBPC3 & $\begin{array}{l}\text { Myosin Binding } \\
\text { Protein C3 }\end{array}$ & p.R326Q & $\begin{array}{l}\text { Electroporation with episomal } \\
\text { plasmids }\end{array}$ & $\mathrm{Ca}^{2+}$ handling deficits & $\mathrm{HCM}$ & [409] \\
\hline MYBPC3 & $\begin{array}{l}\text { Myosin Binding } \\
\text { Protein C3 }\end{array}$ & c. 2373 & Lentiviral transduction & $\begin{array}{l}\text { - Cellular hypertrophy } \\
\text { - } \quad \text { Contractile defect }\end{array}$ & $\mathrm{HCM}$ & {$[410,411]$} \\
\hline МYBРC3 & $\begin{array}{l}\text { Myosin Binding } \\
\text { Protein C3 }\end{array}$ & p.R502W & $\begin{array}{l}\text { Electroporation with episomal } \\
\text { plasmids }\end{array}$ & NA & $\mathrm{HCM}$ & [412] \\
\hline MYBPC3 & $\begin{array}{l}\text { Myosin Binding } \\
\text { Protein C3 }\end{array}$ & $\begin{array}{ll}- & \text { p.R502W } \\
\text { - } & \text { p.W792VfsX41 }\end{array}$ & CRISPR-Cas9 & $\begin{array}{ll}\text { - } & \text { Hypercontractility } \\
\text { - } & \text { P53 activation } \\
\text { - } & \text { Oxidative stress } \\
\text { - } & \text { Metabolic stress }\end{array}$ & $\mathrm{HCM}$ & [413] \\
\hline MYBPC3 & $\begin{array}{l}\text { Myosin Binding } \\
\text { Protein C3 }\end{array}$ & $\begin{array}{ll}\text { - } & \text { p.R943X } \\
\text { - } & \text { p.R1073fsX4 }\end{array}$ & $\begin{array}{l}\text { Sendai virus transduction \& } \\
\text { genome editing for correction } \\
\text { (CRISPR-Cas9) }\end{array}$ & $\begin{array}{l}\text { - } \quad \text { Reduced expression of } M Y B P C 3 \text { at } \\
\text { the mRNA level but not at the } \\
\text { protein level } \\
\text { - } \quad \mathrm{Ca}^{2+} \text { handling defects } \\
\text { - } \quad \text { Activation of nonsense-mediated } \\
\text { mRNA decay }\end{array}$ & $\mathrm{HCM}$ & {$[414,415]$} \\
\hline MYBPC3 & $\begin{array}{l}\text { Myosin Binding } \\
\text { Protein C3 }\end{array}$ & p.G999-Q1004del & Sendai virus transduction & $\begin{array}{ll}\text { - } & \text { Cellular hypertrophy } \\
\text { - } & \text { Myofibrillar disarray } \\
\text { - } & \text { Reduced MYBPC3 expression } \\
\text { - } & \text { Increased ANP expression }\end{array}$ & $\mathrm{HCM}$ & [416] \\
\hline MYBPC3 & $\begin{array}{l}\text { Myosin Binding } \\
\text { Protein C3 }\end{array}$ & p.Q1061X & $\begin{array}{ll}\text { - } & \text { Sendai virus transduction } \\
\text { - } & \text { Retroviral transduction }\end{array}$ & Arrhythmias & $\mathrm{HCM}$ & {$[417,418]$} \\
\hline
\end{tabular}


Table 2. Cont.

\begin{tabular}{|c|c|c|c|c|c|c|}
\hline Gene & Protein & Mutation(s) & Method of Generation & Main Phenotypic Findings & $\begin{array}{l}\text { Associated } \\
\text { Disease }\end{array}$ & References \\
\hline МYBРC3 & $\begin{array}{l}\text { Myosin Binding } \\
\text { Protein C3 }\end{array}$ & p.V454CfsX21 & Retroviral transduction & $\begin{array}{ll}\text { - } & \text { Haploinsufficiency (at the mRNA } \\
\text { and protein level) } \\
\text { - } & \text { Cellular hypertrophy } \\
\text { - } & \text { Altered gene expression } \\
\text { - } & \text { Efficient gene replacement using } \\
& \text { AAV9 reduce phenotypic findings }\end{array}$ & $\mathrm{HCM}$ & [419] \\
\hline МYВРСЗ & $\begin{array}{l}\text { Myosin Binding } \\
\text { Protein C3 }\end{array}$ & $\begin{array}{l}\Delta 25 \text { bp in intron } 32 \\
\text { including the splicing } \\
\text { branch point \& p.D389V } \\
\text { (same allele) }\end{array}$ & Sendai virus transduction & $\begin{array}{l}\text { - } \quad \text { Cellular hypertrophy } \\
\text { - } \quad \mathrm{Ca}^{2+} \text { handling deficits }\end{array}$ & $\mathrm{HCM}$ & [420] \\
\hline MYBPHL & $\begin{array}{l}\text { Myosin Binding Protein } \\
\text { H-Like }\end{array}$ & p.R255X & $\begin{array}{l}\text { Electroporation with episomal } \\
\text { plasmids }\end{array}$ & $\begin{array}{l}\text { Haploinsufficiency by nonsense } \\
\text { mediated mRNA decay }\end{array}$ & $\begin{array}{c}\text { DCM \& } \\
\text { conduction } \\
\text { disorders }\end{array}$ & [187] \\
\hline MYH7 & Myosin Heavy Chain 7 & p.R663H & Sendai virus transduction & Abnormal $\mathrm{Ca}^{2+}$ handling & $\mathrm{HCM}$ & [408] \\
\hline MYH7 & Myosin Heavy Chain 7 & $\begin{array}{l}\text { - } \quad \text { p.R } 453 C^{\text {het }} \\
\text { - } \quad \text { p.R } 453 C^{\text {hom }}\end{array}$ & CRISPR-Cas9 & $\begin{array}{ll}\text { - } & \text { Cellular hypertrophy } \\
\text { - } & \text { Sarcomeric disarray } \\
\text { - } & \text { Increased expression of } \\
& \text { hypertrophy markers } \\
\text { - } & \mathrm{Ca}^{2+} \text { handling deficits }\end{array}$ & $\mathrm{HCM}$ & [421] \\
\hline MYH7 & Myosin Heavy Chain 7 & $\begin{array}{ll}\text { - } & \text { p.R403Q } \\
\text { - } & \text { p.V606M }\end{array}$ & CRISPR-Cas9 & $\begin{array}{ll}\text { - } & \text { Hypercontractility } \\
\text { - } & \text { P53 activation } \\
\text { - } & \text { Oxidative stress } \\
\text { - } & \text { Metabolic stress }\end{array}$ & $\mathrm{HCM}$ & [413] \\
\hline MYH7 & Myosin Heavy Chain 7 & p.V698A & $\begin{array}{l}\text { Electroporation with episomal } \\
\text { plasmids }\end{array}$ & NA & $\mathrm{HCM}$ & [422] \\
\hline MYH7 & Myosin Heavy Chain 7 & p.E848G & $\begin{array}{l}\text { Electroporation with episomal } \\
\text { plasmids }\end{array}$ & Reduced contractile function & $\mathrm{HCM}$ & {$[423,424]$} \\
\hline MYH7 & Myosin Heavy Chain 7 & p.R403Q & $\begin{array}{l}\text { Electroporation with episomal } \\
\text { plasmids }\end{array}$ & NA & $\mathrm{HCM}$ & [425] \\
\hline MYH7 & Myosin Heavy Chain 7 & p.R633H & Lentiviral transduction & $\begin{array}{ll}\text { - } & \mathrm{Ca}^{2+} \text { handling deficits } \\
\text { - } & \text { Arrhythmias } \\
\text { - } & \text { Cellular hypertrophy }\end{array}$ & $\mathrm{HCM}$ & {$[414,426]$} \\
\hline
\end{tabular}


Table 2. Cont.

\begin{tabular}{|c|c|c|c|c|c|c|}
\hline Gene & Protein & Mutation(s) & Method of Generation & Main Phenotypic Findings & $\begin{array}{l}\text { Associated } \\
\text { Disease }\end{array}$ & References \\
\hline MYH7 & Myosin Heavy Chain 7 & p.R442G & Retroviral transduction & $\begin{array}{ll}\text { - } & \text { Disorganized sarcomeres } \\
\text { - } & \text { Increased expression of genes } \\
\text { involved in cell proliferation } \\
\text { - } & \text { Electrophysiological alterations }\end{array}$ & $\mathrm{HCM}$ & [427] \\
\hline$M Y L 2$ & Myosin Light Chain 2 & p.R58Q & $\begin{array}{l}\text { Non-integrating } \\
\text { mRNA/miRNA technology }\end{array}$ & $\begin{array}{ll}\text { - } & \text { Cellular hypertrophy } \\
\text { - } & \text { Myofibrillar disarray } \\
\text { - } & \text { Irregular contraction } \\
\text { - } & \text { Decreased } \mathrm{Ca}^{2+} \text { transients }\end{array}$ & $\mathrm{HCM}$ & [428] \\
\hline$M Y L 3$ & Myosin Light Chain 3 & $\begin{array}{ll}\text { - } & \text { p.A57D } \\
\text { - } & \text { p.A57D } \\
\text { - } & \text { p.A57Gh } \\
\text { het }\end{array}$ & CRISPR-Cas9 & $\begin{array}{ll}\text { - } & \text { Asymptomatic } \\
\text { Classification of benign GSVs }\end{array}$ & $\mathrm{HCM}$ & [375] \\
\hline PKP2 & Plakophilin-2 & p.L614P & Retroviral transduction & $\begin{array}{ll}\text { - } & \text { Reduced expression } \\
\text { of plakophilin-2 } \\
\text { - } & \text { Adipogenic phenotype }\end{array}$ & $\mathrm{ACM}$ & [429] \\
\hline PKP2 & Plakophilin-2 & $\begin{array}{ll}- & \text { c. } 2484 C>T^{\text {hom }} \\
\text { - } & \text { c.2013delC }\end{array}$ & Retroviral transduction & $\begin{array}{ll}\text { - } & \text { Lipogenesis } \\
\text { - } & \text { Apoptosis } \\
\text { - } & \mathrm{Ca}^{2+} \text { handling deficits } \\
\text { - } & \text { Pro-fibrotic gene expression } \\
\text { - } & \text { Dysregulation of genes, encoding } \\
& \text { cell-cell connections. }\end{array}$ & $\mathrm{ACM}$ & [430-432] \\
\hline PKP2 & Plakophilin-2 & c.972insT & Retroviral transduction & $\begin{array}{l}\text { - } \quad \begin{array}{l}\text { Reduced expression } \\
\text { of plakophilin-2 }\end{array} \\
\text { - } \quad \text { Changes of the } \\
\text { desmosomal structure } \\
\text { - } \quad \text { Lipid droplet accumulation }\end{array}$ & $\mathrm{ACM}$ & [433] \\
\hline PKP2 & Plakophilin-2 & $\begin{array}{ll}\text { - } & \text { c.354delT } \\
\text { - } & \text { p.K859R }\end{array}$ & Sendai virus transduction & NA & $\mathrm{ACM}$ & [434] \\
\hline$P K P 2$ & Plakophilin-2 & c.2569_3018del50 & $\begin{array}{l}\text { Electroporation with episomal } \\
\text { plasmids }\end{array}$ & NA & $\mathrm{ACM}$ & [435] \\
\hline
\end{tabular}


Table 2. Cont

\begin{tabular}{|c|c|c|c|c|c|c|}
\hline Gene & Protein & Mutation(s) & Method of Generation & Main Phenotypic Findings & $\begin{array}{l}\text { Associated } \\
\text { Disease }\end{array}$ & References \\
\hline PLN & Phospholamban & p.R9C & CRISPR-Cas9 & $\begin{array}{ll}\text { - } & \text { Cellular hypertrophy } \\
\text { - } & \mathrm{Ca}^{2+} \text { handling deficits } \\
\text { - } & \text { Increased expression of } \\
& \text { hypertrophic markers } \\
\text { - } & \text { Altered metabolic state } \\
\text { - } & \text { Changes of miRNA expression } \\
\text { - } & \text { Increased expression of } \\
& \text { profibrotic genes }\end{array}$ & DCM & {$[414,436]$} \\
\hline$P L N$ & Phospholamban & p.R14del & $\begin{array}{l}\text { Transfection with mRNAs\& } \\
\text { genome editing (TALENs) for } \\
\text { mutation correction }\end{array}$ & $\begin{array}{l}\text { - } \quad \mathrm{Ca}^{2+} \text { handling deficits } \\
\text { - } \quad \begin{array}{l}\text { Abnormal cytoplasmic localization } \\
\text { of phospholamban }\end{array} \\
\text { - } \quad \begin{array}{l}\text { Increased expression of } \\
\text { hypertrophic markers }\end{array} \\
\text { - } \quad \begin{array}{l}\text { Gene correction reverses the } \\
\text { phenotypic findings }\end{array}\end{array}$ & DCM & {$[437,438]$} \\
\hline PRGAG2 & $\begin{array}{c}\text { Protein Kinase } \\
\text { AMP-Activated } \\
\text { Non-Catalytic Subunit } \\
\text { Gamma } 2\end{array}$ & p.R302Q & $\begin{array}{l}\text { Sendai virus transduction \& } \\
\text { genome editing for correction } \\
\text { (CRISPR-Cas9) }\end{array}$ & $\begin{array}{ll}\text { - } & \text { Arrhythmias } \\
\text { - } & \text { Electrophysiological alterations } \\
\text { - } & \text { Cellular hypertrophy } \\
& \text { Cene correction using } \\
& \text { phenotypic findings }\end{array}$ & $\begin{array}{l}\text { Wolff-Parkin } \\
\text { Syndrome } \\
\text { (HCM) }\end{array}$ & $\begin{array}{l}\text {-White } \\
\text { [439] }\end{array}$ \\
\hline PRKAG2 & $\begin{array}{c}\text { Protein Kinase } \\
\text { AMP-Activated } \\
\text { Non-Catalytic Subunit } \\
\text { Gamma } 2\end{array}$ & p.N488I & $\begin{array}{l}\text { Lentiviral transduction \& } \\
\text { genome editing for correction } \\
\text { (TALEN) }\end{array}$ & $\begin{array}{ll}\text { - } & \text { Activated AMPK } \\
\text { remodeled metabolism } \\
\text { - } & \text { Cellular hypertrophy }\end{array}$ & $\mathrm{HCM}$ & [440] \\
\hline PTPN11 & $\begin{array}{c}\text { Protein Tyrosine } \\
\text { Phosphatase } \\
\text { Non-Receptor Type } 11\end{array}$ & p.T468M & Retroviral transduction & $\begin{array}{ll}\text { - } & \text { Cellular hypertrophy } \\
\text { - } & \text { Impaired sarcomere structure }\end{array}$ & $\begin{array}{l}\text { LEOPARD } \\
\text { Syndrome } \\
\text { (HCM) }\end{array}$ & [360] \\
\hline PTPN11 & $\begin{array}{c}\text { Protein Tyrosine } \\
\text { Phosphatase } \\
\text { Non-Receptor Type } 11\end{array}$ & p.Q510P & Sendai virus transduction & NA & $\begin{array}{l}\text { LEOPARD } \\
\text { Syndrome } \\
\text { (HCM) }\end{array}$ & [441] \\
\hline
\end{tabular}


Table 2. Cont

\begin{tabular}{|c|c|c|c|c|c|c|}
\hline Gene & Protein & Mutation(s) & Method of Generation & Main Phenotypic Findings & $\begin{array}{l}\text { Associated } \\
\text { Disease }\end{array}$ & References \\
\hline RAF1 & $\begin{array}{l}\text { Raf-1 Proto-Oncogene, } \\
\text { Serine/Threonine Kinase }\end{array}$ & p.S257L & $\begin{array}{l}\text { Electroporation of episomal } \\
\text { plasmids \& genome editing for } \\
\text { correction (CRISPR-Cas9) }\end{array}$ & $\begin{array}{ll}\text { - } & \text { Cellular hypertrophy } \\
\text { - } & \text { Myofibrillar disarray } \\
\text { - } & \text { Hyperactivation of } \\
& \text { MEK1/2 pathway } \\
\text { - } & \text { Increased ERK5 signaling }\end{array}$ & $\begin{array}{l}\text { Noonan } \\
\text { Syndrome } \\
\text { (HCM) }\end{array}$ & [442] \\
\hline RBM20 & $\begin{array}{l}\text { RNA Binding Motif } \\
\text { Protein } 20\end{array}$ & p.S635A & Lentiviral transduction & $\begin{array}{ll}\text { - } & \text { Altered } \mathrm{Ca}^{2+} \text { handling } \\
\text { - } & \text { Impaired sarcomere structure } \\
\text { - } & \text { Reduced titin N2B } \\
& \text { isoform expression }\end{array}$ & DCM & [443] \\
\hline RBM20 & $\begin{array}{l}\text { RNA Binding Motif } \\
\text { Protein } 20\end{array}$ & p.R636S & Sendai virus transduction & $\begin{array}{ll}\text { - } & \text { Impaired sarcomere structure } \\
\text { - } & \text { Altered transcriptome } \\
\text { - } & \text { Altered } \mathrm{Ca}^{2+} \text { handling } \\
\text { - } & \text { Apoptotic changes } \\
& \text { Therapeutic treatment using } \\
& \beta \text {-blockers or } \mathrm{Ca}^{2+} \text { channel } \\
& \text { blockers reverse } \\
& \text { phenotypic findings }\end{array}$ & DCM & {$[444,445]$} \\
\hline$R Y R 2$ & Ryanodine Receptor 2 & p.F2483I & Retroviral transduction & $\begin{array}{ll}\text { - } & \text { Arrhythmias } \\
\text { - } & \text { Altered } \mathrm{Ca}^{2+} \text { handling }\end{array}$ & CPVT & {$[350]$} \\
\hline$R Y R 2$ & Ryanodine Receptor 2 & $\begin{array}{ll}\text { - } & \text { p.S404R \& p.N685S } \\
\text { - } & \text { p.G3946S \& p.G1885E }\end{array}$ & Sendai virus transduction & $\begin{array}{l}\text { - } \quad \text { Altered } \mathrm{Ca}^{2+} \text { handling } \\
\text { - Calmodulin-dependent protein } \\
\text { kinase II inhibition reverse } \\
\text { the arrhythmias }\end{array}$ & CPVT & {$[376]$} \\
\hline SCN5A & $\begin{array}{l}\text { Sodium Voltage-Gated } \\
\text { Channel Alpha Subunit } 5\end{array}$ & - $\quad$ p.S1898R & $\begin{array}{l}\text { Sendai virus transduction \& } \\
\text { CRISPR-Cas } 9 \text { for correction }\end{array}$ & - $\quad$ Reduction in peak sodium channel & $\mathrm{ACM}$ & [446] \\
\hline SCN5A & $\begin{array}{l}\text { Sodium Voltage-Gated } \\
\text { Channel Alpha Subunit } 5\end{array}$ & p.R219H & Sendai virus transduction & $\begin{array}{ll}\text { - } & \text { Proton leakage } \\
\text { - } & \text { Disrupted ion homeostasis } \\
\text { - } & \text { Structural abnormalities } \\
\text { - } & \text { Electrophysiological alterations } \\
\text { - } & \text { Reduced contraction }\end{array}$ & $\mathrm{ACM} / \mathrm{DCM}$ & [447] \\
\hline
\end{tabular}


Table 2. Cont

\begin{tabular}{|c|c|c|c|c|c|c|}
\hline Gene & Protein & Mutation(s) & Method of Generation & Main Phenotypic Findings & $\begin{array}{l}\text { Associated } \\
\text { Disease }\end{array}$ & References \\
\hline SCO2 & $\begin{array}{l}\text { SCO2 Cytochrome C } \\
\text { Oxidase Assembly } \\
\text { Protein } \\
\end{array}$ & $\begin{array}{ll}\text { - } & \text { p.E140K } \\
\text { - } & \text { p.G193S hom } \\
\end{array}$ & Sendai virus transduction & $\begin{array}{ll}\text { - } & \text { Structural abnormalities } \\
\text { - } & \text { Altered } \mathrm{Ca}^{2+} \text { handling } \\
\end{array}$ & $\mathrm{HCM}$ & [448] \\
\hline$T A Z$ & Tafazzin & $\begin{array}{ll}- & \text { c.517delG } \\
- & \text { c. } 328 \mathrm{~T}>\mathrm{C}\end{array}$ & $\begin{array}{l}\text { Transfection with synthetic } \\
\text { mRNAs \& CRISPR-Cas9 for } \\
\text { correction }\end{array}$ & $\begin{array}{ll}\text { - } & \text { Impaired sarcomere structure } \\
\text { - } & \text { Decreased contraction } \\
\text { - } & \text { Increased reactive oxygen species }\end{array}$ & $\begin{array}{l}\text { Barth } \\
\text { Syndrome }\end{array}$ & [449] \\
\hline TBX20 & T-Box Factor 20 & $\begin{array}{ll}\text { - } & \text { p.T262M } \\
\text { - } & \text { p.Y317X }\end{array}$ & Sendai virus transduction & $\begin{array}{ll}- & \text { Perturbed TGF } \beta \text { signaling } \\
\text { - } & \text { Reduced expression of cardiac } \\
\text { transcription factors }\end{array}$ & LVNC & [450] \\
\hline TNNT2 & Cardiac Troponin T & p.R92W & $\begin{array}{l}\text { Sendai virus transduction \& } \\
\text { CRISPR-Cas9 for correction }\end{array}$ & Abnormal $\mathrm{Ca}^{2+}$ handling & $\mathrm{HCM}$ & [408] \\
\hline TNNT2 & Cardiac Troponin T & p.R173W & Lentiviral transduction & $\begin{array}{ll}\text { - } & \text { Decreased contractility } \\
\text { - } & \text { Altered } \mathrm{Ca}^{2+} \text { handling } \\
\text { - } & \text { Impaired sarcomere structure }\end{array}$ & $\mathrm{DCM}$ & {$[414,451-454]$} \\
\hline TNNT2 & Cardiac Troponin T & 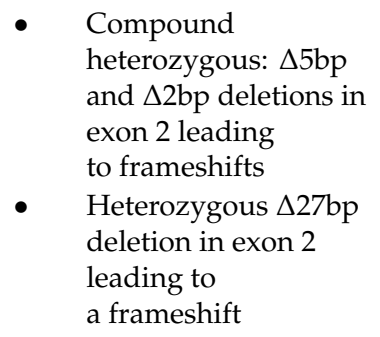 & TALEN & $\begin{array}{ll}\text { - } & \text { Sarcomere disassembly } \\
\text { - } & \text { Altered } \mathrm{Ca}^{2+} \text { handling }\end{array}$ & $\mathrm{DCM} / \mathrm{HCM}$ & [453] \\
\hline TNNT2 & Cardiac Troponin T & p.I79N & CRISPR-Cas9 & $\begin{array}{ll}\text { - } & \text { Impaired sarcomere structure } \\
\text { - } & \text { Increased systolic function } \\
\text { - } & \text { Impaired relaxation } \\
\text { - } & \text { Altered } \mathrm{Ca}^{2+} \text { handling }\end{array}$ & $\mathrm{HCM}$ & {$[455,456]$} \\
\hline TPM1 & Tropomyosin-1 & p.D175N & $\begin{array}{ll}- & \text { Sendai virus transduction } \\
\text { - } & \text { Retroviral transduction }\end{array}$ & Arrhythmias & $\mathrm{HCM}$ & {$[417,418]$} \\
\hline
\end{tabular}


Table 2. Cont

\begin{tabular}{|c|c|c|c|c|c|c|}
\hline Gene & Protein & Mutation(s) & Method of Generation & Main Phenotypic Findings & $\begin{array}{l}\text { Associated } \\
\text { Disease }\end{array}$ & References \\
\hline TTN & Titin & p.S14450fsX4 & Sendai virus transduction & $\begin{array}{l}\text { Antisense-mediated exon skipping } \\
\text { restores titin expression }\end{array}$ & DCM & [377] \\
\hline TTN & Titin & 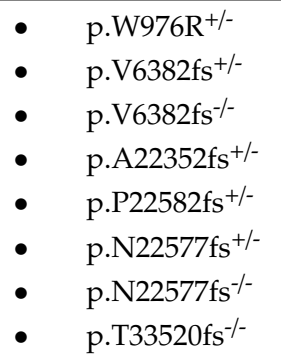 & $\begin{array}{ll}-\quad & \text { Lentiviral transduction } \\
\text { (for patient specific iPSC) } \\
\text { CRISPR-Cas9 (for } \\
\text { generation of } \\
\text { isogenic iPSC) }\end{array}$ & $\begin{array}{l}\text { - } \quad \text { Impaired sarcomere structure } \\
\text { - } \quad \text { Decreased contractility } \\
\text { Diminished activation of growth } \\
\text { factors, hypoxia regulating factors } \\
\text { and MAP kinases }\end{array}$ & $\mathrm{DCM}$ & [457] \\
\hline TTN & Titin & $\begin{array}{ll}\text { - } & \text { c.86076dupA } \\
\text { - } & \text { c.70690dupAT }\end{array}$ & Lentiviral transduction & $\begin{array}{ll}\text { - } & \text { Sarcomere defects } \\
\text { - } & \text { Diminished inotropic and } \\
\text { lusitropic responses }\end{array}$ & DCM & [458] \\
\hline$T T R$ & Transthyretin & p.L55P & Lentiviral transduction & Increased oxidative stress & $\begin{array}{l}\text { Hereditary } \\
\text { Transthyretin } \\
\text { Amyloidosis }\end{array}$ & [459] \\
\hline
\end{tabular}

ACM-Arrhythmogenic cardiomyopathy; CFCS—Cardio facio cutaneous syndrome; CM-Cardiomyopathy; CPVT-Catecholaminergic polymorphic ventricular tachycardia; DCM-Dilated cardiomyopathy; DMD—Duchenne muscular dystrophy; DRC—Desmin-related cardiomyopathy; HCM-Hypertrophic cardiomyopathy; LVNC-Left-ventricular non-compaction cardiomyopathy; MFM-Myofibrillar myopathy; MP-Myopathy; NA-Not assessed; RCM-Restrictive cardiomyopathy. 


\section{Limitations of Human Induced Pluripotent Stem-Cell-Derived Cardiomyocytes}

Besides cardiomyocytes, the human adult heart consists of several different cell types like fibroblasts, endothelial cells, leukocytes, pericytes, and smooth muscle cells. It has been estimated that the proportion of cardiomyocytes in myocardial tissue is around $25-35 \%$, indicating that the majority of the cardiac cells are non-cardiomyocytes [460]. However, the molecular and cellular interactions and interferences between the different cardiac cell types are poorly understood. In particular, under pathological conditions like inflammation or fibrosis, the cellular composition of the heart of cardiomyopathy patients can vary and might change over time. Therefore, it is in general challenging to model the complex cellular and molecular networks using iPSC-derived cardiomyocytes in vitro, although the artificial generation of cardiac tissue has been impressively improved during the last few years [461-465]. Besides these general limitations, iPSCs and iPSC-derived cardiomyocytes have some specific limitations, which are outlined in the following paragraphs.

\subsection{Genomic Instability}

Genomic instability of iPSCs can be a fundamental problem limiting the clinical application of iPSC-derived cells because of safety concerns [466]. Mayshar et al. showed that a significant portion of iPSC and ESC lines carry full or partial chromosomal aberrations [467]. However, even for in vitro analysis, genomic instability could be an important issue, especially in the context of modeling genetic diseases like cardiomyopathies. Therefore, novel iPSC lines should be genetically characterized in general. Karyotype analysis using Giemsa staining or comparative genomic hybridization arrays can be used to detect larger chromosomal abnormalities, while next generation sequencing assays can be applied for genetic analysis at the single nucleotide level.

Three different mechanisms contribute to the mutagenesis in iPSCs: besides the existence of genetic variants in the parental somatic donor cells, mutations can be introduced during reprogramming procedure or during the long-time culture of iPSCs [468]. Of note, mutations might accumulate in iPSCs over the culturing time [469]. Therefore, it is advisable to use early passages and to repeat analyses for genetic stability from time to time.

\subsection{Heterogeneity of iPSC-Derived Cardiomyocytes}

Although cardiac differentiation protocols for iPSCs have been improved significantly over recent years [345,470], it should be kept in mind that iPSC-derived cardiomyocytes are still a heterogeneous cell population. Especially for bulk down-stream applications like proteomics, genomics, or metabolomics, this might have a significant impact.

\subsection{Cellular, Molecular, and Functional Differences of Adult Ventricular Cardiomyocytes and iPSC-Derived Cardiomyocytes}

Even though human iPSC-derived cardiomyocytes are contractile cell types, there are important cellular, molecular, and functional differences compared to adult cardiomyocytes. The most obvious differences are the size and shape of iPSC-derived cardiomyocytes. Adult ventricular cardiomyocytes have a typical rod-like shape and are relatively large cells with lengths of about $100 \mu \mathrm{m}$ and diameters of 10-25 $\mu \mathrm{m}$ [471]. In contrast, iPSC-derived cardiomyocytes are much smaller [472] and are morphologically heterogeneous. The geometry of iPSC-derived cardiomyocytes ranges from round to rectangular or polygonal shapes [473,474]. In adult ventricular cardiomyocytes, the sarcomeric structure is highly organized and the Z-bands are in parallel with the intercalated disc. On the contrary, iPSC-derived cardiomyocytes have a more irregular and amorphous sarcomeric organization with diverse orientations [462,475]. In human myocardial tissue, the closed-ends of the plasma membranes connect the cardiomyocytes longitudinally and these ends of the cardiomyocytes "cylinders" are called intercalated discs. Multi-protein complexes mediate the cell-cell interactions at the intercalated discs and are subdivided into desmosomes, adherens, and gap junctions [476]. Although desmosomes and 
adherens junctions are also formed in iPSC-derived cardiomyocytes [472,477], the cellular distribution of these cell-cell junctions are not conserved [478,479]. Another important difference is the number of nuclei. Whereas a significant number of the human cardiomyocytes in vivo are binuclear cells [480], iPSC-derived cardiomyocytes are mononuclear cells [481]. In addition, there are significant differences in contraction and electrical properties of iPSC-derived cardiomyocytes in comparison to adult ones [474]. In summary, the structural and functional properties of iPSC-derived cardiomyocytes are more similar to fetal cardiomyocytes than to adult cardiomyocytes [482]. To overcome these limitations, different natural engineering approaches were established to drive cardiomyocytes maturation. One method is to stimulate the cardiomyocytes with electrical or mechanical impulses [483]. The composition of the extracellular matrix can also affect the interaction of the CMs, therefore influencing the cellular behavior [484,485]. Another promising approach is the co-culture of iPSC-derived cardiomyocytes with non-cardiomyocytes, enabling a more likely cardiac environment with different cellular interactions [486]. Physical, chemical, electrical, and genetic factors are being tested as stimuli for further maturation [487]. However, maturation of iPSC-derived cardiomyocytes is incompletely understood at the molecular level and more studies are needed in future.

\section{Testing of Gene Therapies Using iPSC-Derived Cardiomyocytes as in Vitro Models}

An interesting research topic is the development of personalized therapeutic strategies for genetic cardiomyopathies in vitro. Beyond the opportunities that reprogramming technologies offer for therapeutic myocardial regeneration, iPSC-derived cardiomyocytes are a promising platform to develop and test different gene therapies for genetic, non-ischemic cardiomyopathies. In general, the pathomechanisms of inherited cardiomyopathies can be classified into loss of function (LOF) or gain of function (GOF) mechanisms. LOF can be caused by (haplo)insufficiency or by the expression of non-functional proteins. For example, several HCM-associated MYBPC3 mutations cause haploinsufficiency [415,488]. GOF is caused by mutant and toxic proteins such as those shown for several DES missense mutations [489,490].

Genome editing using CRISPR-Cas9 or TALENs has been applied to repair different mutations in iPSC-derived cardiomyocytes. After the insertion of DSBs, iPSCs repair these DSBs using NHEJ or HDR. Template molecules like oligonucleotides, plasmids, PCR products, or even the second chromosome might be used for HDR. Recently, Ma et al. even applied CRISPR-Cas9 for the repair of a pathogenic MYBPC3 mutation in human pre-implanted embryos [491]. However, because the efficiency of HDR is low, the direct repair of mutations in iPSCs via genome editing is challenging. Therefore, single iPSC clones were frequently generated in vitro and the direct translational transfer of this method is consequently limited. A second therapeutic strategy is exon skipping [492]. Exon skipping corrects the open reading frame (ORF) of an affected gene via skipping of the mutant or multiple exons and restores the expression of the truncated, but still functional, protein. For this approach, specific antisense oligonucleotides binding to the mutant exons can be used [493]. Besides its application in iPSC-derived cardiomyocytes carrying mutations in DMD [494] or TTN [377], antisense-mediated exon skipping was also directly applied in human patients with Duchenne's muscular dystrophy [495]. Recently, Eric Olson's group applied CRISPR-CPF1 or -Cas9-mediated genome editing for exon skipping in iPSC-derived cardiomyocytes [379,496,497]. Prondzynski et al. applied trans-splicing and total gene replacement for the artificial increased expression of $M Y B P C 3$ in iPSC-derived cardiomyocytes carrying a heterozygous frameshift mutation in MYBPC3 [419]. The authors used adeno-associated viruses (serotype 2/9, AAV2/9) for the transduction of iPSC-derived cardiomyocytes with $5^{\prime}$ - and 3'-pre-trans-splicing molecules and the total cDNA of MYBPC3. However, the efficiency of the trans-splicing approach was low. In contrast, the total gene replacement strategy increased the MYBPC 3 expression to over $80 \%$ in comparison with wild-type controls and was able to prevent cellular hypertrophy [419]. 
The combination of the iPSC-derived cardiomyocytes platform with gene therapy tools is a promising therapeutic approach enabling pre-clinical demonstration of proof-of-principle for inherited cardiomyopathies.

\section{Summary}

Human iPSC-derived cardiomyocytes represent the only available human cellular model for the direct functional analysis of specific genetic cardiomyopathies and might therefore overcome the limitation of species differences. Impressive progress in the reprogramming and differentiation procedure during the last decade allows, in combination with novel genome editing techniques like CRISPR-Cas9, for the development of defined/patient specific cardiomyocyte models including generation of their isogenic control lines. In summary, iPSC-derived cardiomyocytes have been used for: (a) the characterization of genetic variants of unknown significance, which might be helpful for genetic counseling [375]; (b) analyses of the molecular pathomechanisms [415]; and (c) the development of specific therapies $[377,497]$.

However, the cellular and molecular crosstalk between inflammatory cells, fibroblasts, myoblasts, and cardiomyocytes is difficult to model using iPSC-derived cardiomyocytes. Therefore, in our opinion, iPSC-derived cardiomyocytes should also be combined with animal models or with ex vivo investigations of explanted human myocardial tissue whenever possible to overcome the specific limitations of iPSC-derived cardiomyocytes.

Interestingly, for some genes like $D M D, P K P 2, M Y B P C 3$, or $M Y H 7$, several different iPSC lines have been generated. In contrast, for rare cardiomyopathy genes, e.g., TMEM43, no iPSC lines have been developed yet. The genetic analysis in the past few decades has revealed a high heterogeneity of inherited, non-ischemic cardiomyopathies. In our view, it is therefore important to generate further novel iPSC lines also carrying mutations in rare cardiomyopathy genes to compare the molecular differences and commonalities leading to non-ischemic cardiomyopathies. Hopefully, iPSC-derived cardiomyocytes will contribute to unravelling the pathomechanisms of genetic cardiomyopathies and will help in efficient drug development in future.

Gene names follow the official guidelines of the HUGO Gene Nomenclature Committee (HGNC, https://www.genenames.org/) [498].

Author Contributions: Writing and original draft preparation-A.B., H.E., and S.R; figure preparation-A.B.; review and editing-M.A.D., A.G., J.G., and H.M.

Funding: A.B., J.G., and H.M. are thankful for financial support of the German Foundation for Heart Research (DSHF, F07/17) and by the University of Bielefeld (Forschungsfonds Medizin in der Region OWL). H.E. received a Kaltenbach scholarship from the German Heart Foundation. H.M. received a grant from the German Research Foundation (DFG, MI-1146/2-1).

Conflicts of Interest: The authors declare no conflict of interest.

\section{Abbreviations}

$\begin{array}{ll}\text { ACMG } & \text { American College of Medical Genetics and Genomics Institute } \\ \text { ACM } & \text { Arrhythmogenic Cardiomyopathy } \\ \text { CM } & \text { Cardiomyopathy } \\ \text { DCM } & \text { Dilated Cardiomyopathy } \\ \text { ESC } & \text { Embryonic Stem Cell } \\ \text { HCM } & \text { Hypertrophic Cardiomyopathy } \\ \text { iPSC } & \text { Induced Pluripotent Stem Cell } \\ \text { HTx } & \text { Heart Transplantation } \\ \text { NCCM } & \text { Non-Compaction Cardiomyopathy } \\ \text { MP } & \text { Myopathy } \\ \text { NMD } & \text { Nonsense Mediated RNA Decay } \\ \text { RCM } & \text { Restrictive Cardiomyopathy }\end{array}$




\section{References}

1. Green, E.D.; Watson, J.D.; Collins, F.S. Human genome project: Twenty-five years of big biology. Nat. News 2015, 526, 29-31. [CrossRef] [PubMed]

2. Brodehl, A.; Ebbinghaus, H.; Gaertner-Rommel, A.; Stanasiuk, C.; Klauke, B.; Milting, H. Functional analysis of DES-p.L398P and RBM20-p.R636C. Genet. Med. 2019, 21, 1246-1247. [CrossRef] [PubMed]

3. Richards, S.; Aziz, N.; Bale, S.; Bick, D.; Das, S.; Gastier-Foster, J.; Grody, W.W.; Hegde, M.; Lyon, E.; Spector, E.; et al. Standards and guidelines for the interpretation of sequence variants: A joint consensus recommendation of the American College of Medical Genet. and Genomics and the Association for Molecular Pathology. Genet. Med. 2015, 17, 405-424. [CrossRef] [PubMed]

4. Maron, B.J.; Towbin, J.A.; Thiene, G.; Antzelevitch, C.; Corrado, D.; Arnett, D.; Moss, A.J.; Seidman, C.E.; Young, J.B.; American Heart, A.; et al. Contemporary definitions and classification of the cardiomyopathies: An american heart association scientific statement from the council on clinical cardiology, heart failure and transplantation committee; Quality of care and outcomes research and functional genomics and translational biology interdisciplinary working groups; and council on epidemiology and prevention. Circulation 2006, 113, 1807-1816. [PubMed]

5. Alraies, M.C.; Eckman, P. Adult heart transplant: Indications and outcomes. J. Thorac. Dis. 2014, 6, 1120-1128. [PubMed]

6. Minoche, A.E.; Horvat, C.; Johnson, R.; Gayevskiy, V.; Morton, S.U.; Drew, A.P.; Woo, K.; Statham, A.L.; Lundie, B.; Bagnall, R.D.; et al. Genome sequencing as a first-line genetic test in familial dilated cardiomyopathy. Genet. Med. 2019, 21, 650-662. [CrossRef] [PubMed]

7. Kolokotronis, K.; Kuhnisch, J.; Klopocki, E.; Dartsch, J.; Rost, S.; Huculak, C.; Mearini, G.; Stork, S.; Carrier, L.; Klaassen, S.; et al. Biallelic mutation in MYH7 and MYBPC3 leads to severe cardiomyopathy with left ventricular noncompaction phenotype. Hum. Mutat. 2019, 40, 1101-1114. [CrossRef] [PubMed]

8. Hershberger, R.E.; Givertz, M.M.; Ho, C.Y.; Judge, D.P.; Kantor, P.F.; McBride, K.L.; Morales, A.; Taylor, M.R.G.; Vatta, M.; Ware, S.M.; et al. Genetic evaluation of cardiomyopathy: A clinical practice resource of the American College of Medical Genet. and Genomics (ACMG). Genet. Med. 2018, 20, 899-909. [CrossRef]

9. Merner, N.D.; Hodgkinson, K.A.; Haywood, A.F.; Connors, S.; French, V.M.; Drenckhahn, J.D.; Kupprion, C.; Ramadanova, K.; Thierfelder, L.; McKenna, W.; et al. Arrhythmogenic right ventricular cardiomyopathy type 5 is a fully penetrant, lethal arrhythmic disorder caused by a missense mutation in the TMEM43 gene. Am. J. Hum. Genet. 2008, 82, 809-821. [CrossRef] [PubMed]

10. Milting, H.; Klauke, B.; Christensen, A.H.; Musebeck, J.; Walhorn, V.; Grannemann, S.; Munnich, T.; Saric, T.; Rasmussen, T.B.; Jensen, H.K.; et al. The TMEM43 Newfoundland mutation p.S358L causing ARVC-5 was imported from Europe and increases the stiffness of the cell nucleus. Eur. Heart J. 2015, 36, 872-881. [CrossRef]

11. Christensen, A.H.; Andersen, C.B.; Tybjaerg-Hansen, A.; Haunso, S.; Svendsen, J.H. Mutation analysis and evaluation of the cardiac localization of TMEM43 in arrhythmogenic right ventricular cardiomyopathy. Clin. Genet. 2011, 80, 256-264. [CrossRef] [PubMed]

12. Stroud, M.J.; Fang, X.; Zhang, J.; Guimaraes-Camboa, N.; Veevers, J.; Dalton, N.D.; Gu, Y.; Bradford, W.H.; Peterson, K.L.; Evans, S.M.; et al. Luma is not essential for murine cardiac development and function. Cardiovasc. Res. 2018, 114, 378-388. [CrossRef]

13. Figulla, H.R.; Wiegand, V.; Kreuzer, H. Dilated cardiomyopathy. Dtsch. Med. Wochenschr. 1989, 114, 66-70. [CrossRef] [PubMed]

14. Seidman, C.E.; Seidman, J.G. Identifying sarcomere gene mutations in hypertrophic cardiomyopathy: A personal history. Circ. Res. 2011, 108, 743-750. [CrossRef] [PubMed]

15. Muchtar, E.; Blauwet, L.A.; Gertz, M.A. Restrictive cardiomyopathy: Genetics, pathogenesis, clinical manifestations, diagnosis, and therapy. Circ. Res. 2017, 121, 819-837. [CrossRef]

16. Shariati, J.; Schlosser, T.; Erbel, R. Noncompaction cardiomyopathy. Herz 2015, 40, 583-590. [CrossRef] [PubMed]

17. Fazio, G.; Corrado, G.; Novo, G.; Zachara, E.; Rapezzi, C.; Sulafa, A.K.; Sutera, L.; D’Angelo, L.; Visconti, C.; Stollberger, C.; et al. Ventricular dysfunction and number of non compacted segments in non compaction: Non-independent predictors. Int. J. Cardiol. 2010, 141, 250-253. [CrossRef] [PubMed] 
18. Gandjbakhch, E.; Redheuil, A.; Pousset, F.; Charron, P.; Frank, R. Clinical diagnosis, imaging, and genetics of arrhythmogenic right ventricular cardiomyopathy/dysplasia: JACC state-of-the-art review. J. Am. Coll. Cardiol. 2018, 72, 784-804. [CrossRef]

19. Basso, C.; Corrado, D.; Marcus, F.I.; Nava, A.; Thiene, G. Arrhythmogenic right ventricular cardiomyopathy. Lancet 2009, 373, 1289-1300. [CrossRef]

20. Marcus, F.I.; Fontaine, G.H.; Guiraudon, G.; Frank, R.; Laurenceau, J.L.; Malergue, C.; Grosgogeat, Y. Right ventricular dysplasia: A report of 24 adult cases. Circulation 1982, 65, 384-398. [CrossRef]

21. Corrado, D.; Basso, C.; Thiene, G.; McKenna, W.J.; Davies, M.J.; Fontaliran, F.; Nava, A.; Silvestri, F.; Blomstrom-Lundqvist, C.; Wlodarska, E.K.; et al. Spectrum of clinicopathologic manifestations of arrhythmogenic right ventricular cardiomyopathy/dysplasia: A multicenter study. J. Am. Coll. Cardiol. 1997, 30, 1512-1520. [CrossRef]

22. Geisterfer-Lowrance, A.A.; Kass, S.; Tanigawa, G.; Vosberg, H.P.; McKenna, W.; Seidman, C.E.; Seidman, J.G. A molecular basis for familial hypertrophic cardiomyopathy: A beta cardiac myosin heavy chain gene missense mutation. Cell 1990, 62, 999-1006. [CrossRef]

23. Li, D.; Tapscoft, T.; Gonzalez, O.; Burch, P.E.; Quinones, M.A.; Zoghbi, W.A.; Hill, R.; Bachinski, L.L.; Mann, D.L.; Roberts, R. Desmin mutation responsible for idiopathic dilated cardiomyopathy. Circulation 1999, 100, 461-464. [CrossRef] [PubMed]

24. Brodehl, A.; Dieding, M.; Biere, N.; Unger, A.; Klauke, B.; Walhorn, V.; Gummert, J.; Schulz, U.; Linke, W.A.; Gerull, B.; et al. Functional characterization of the novel DES mutation p.L136P associated with dilated cardiomyopathy reveals a dominant filament assembly defect. J. Mol. Cell. Cardiol. 2016, 91, 207-214. [CrossRef] [PubMed]

25. Harada, H.; Hayashi, T.; Nishi, H.; Kusaba, K.; Koga, Y.; Koga, Y.; Nonaka, I.; Kimura, A. Phenotypic expression of a novel desmin gene mutation: Hypertrophic cardiomyopathy followed by systemic myopathy. J. Hum. Genet. 2018, 63, 249-254. [CrossRef] [PubMed]

26. Klauke, B.; Kossmann, S.; Gaertner, A.; Brand, K.; Stork, I.; Brodehl, A.; Dieding, M.; Walhorn, V.; Anselmetti, D.; Gerdes, D.; et al. De novo desmin-mutation N116S is associated with arrhythmogenic right ventricular cardiomyopathy. Hum. Mol. Genet. 2010, 19, 4595-4607. [CrossRef] [PubMed]

27. Bermudez-Jimenez, F.J.; Carriel, V.; Brodehl, A.; Alaminos, M.; Campos, A.; Schirmer, I.; Milting, H.; Abril, B.A.; Alvarez, M.; Lopez-Fernandez, S.; et al. Novel desmin mutation p.Glu401Asp impairs filament formation, disrupts cell membrane integrity, and causes severe arrhythmogenic left ventricular cardiomyopathy/dysplasia. Circulation 2018, 137, 1595-1610. [CrossRef] [PubMed]

28. Pruszczyk, P.; Kostera-Pruszczyk, A.; Shatunov, A.; Goudeau, B.; Draminska, A.; Takeda, K.; Sambuughin, N.; Vicart, P.; Strelkov, S.V.; Goldfarb, L.G.; et al. Restrictive cardiomyopathy with atrioventricular conduction block resulting from a desmin mutation. Int. J. Cardiol. 2007, 117, 244-253. [CrossRef] [PubMed]

29. Fan, P.; Lu, C.X.; Dong, X.Q.; Zhu, D.; Yang, K.Q.; Liu, K.Q.; Zhang, D.; Zhang, Y.; Meng, X.; Tan, H.Q.; et al. A novel phenotype with splicing mutation identified in a Chinese family with desminopathy. Chin. Med. J. 2019, 132, 127-134. [CrossRef] [PubMed]

30. Marakhonov, A.V.; Brodehl, A.; Myasnikov, R.P.; Sparber, P.A.; Kiseleva, A.V.; Kulikova, O.V.; Meshkov, A.N.; Zharikova, A.A.; Koretsky, S.N.; Kharlap, M.S.; et al. Non-compaction cardiomyopathy is caused by a novel in-frame desmin $(D E S)$ deletion mutation within the 1A coiled-coil rod segment leading to a severe filament assembly defect. Hum. Mutat. 2019. [CrossRef] [PubMed]

31. Brodehl, A.; Gaertner-Rommel, A.; Milting, H. Molecular insights into cardiomyopathies associated with desmin (DES) mutations. Biophys. Rev. 2018, 10, 983-1006. [CrossRef] [PubMed]

32. Gerull, B.; Gramlich, M.; Atherton, J.; McNabb, M.; Trombitas, K.; Sasse-Klaassen, S.; Seidman, J.G.; Seidman, C.; Granzier, H.; Labeit, S.; et al. Mutations of TTN, encoding the giant muscle filament titin, cause familial dilated cardiomyopathy. Nat. Genet. 2002, 30, 201-204. [CrossRef] [PubMed]

33. Taylor, M.; Graw, S.; Sinagra, G.; Barnes, C.; Slavov, D.; Brun, F.; Pinamonti, B.; Salcedo, E.E.; Sauer, W.; Pyxaras, S.; et al. Genetic variation in titin in arrhythmogenic right ventricular cardiomyopathy-overlap syndromes. Circulation 2011, 124, 876-885. [CrossRef] [PubMed]

34. Peled, Y.; Gramlich, M.; Yoskovitz, G.; Feinberg, M.S.; Afek, A.; Polak-Charcon, S.; Pras, E.; Sela, B.A.; Konen, E.; Weissbrod, O.; et al. Titin mutation in familial restrictive cardiomyopathy. Int. J. Cardiol. 2014, 171, 24-30. [CrossRef] [PubMed] 
35. Haas, J.; Frese, K.S.; Peil, B.; Kloos, W.; Keller, A.; Nietsch, R.; Feng, Z.; Muller, S.; Kayvanpour, E.; Vogel, B.; et al. Atlas of the clinical genetics of human dilated cardiomyopathy. Eur. Heart J. 2015, 36, 1123-1135. [CrossRef] [PubMed]

36. Pugh, T.J.; Kelly, M.A.; Gowrisankar, S.; Hynes, E.; Seidman, M.A.; Baxter, S.M.; Bowser, M.; Harrison, B.; Aaron, D.; Mahanta, L.M.; et al. The landscape of genetic variation in dilated cardiomyopathy as surveyed by clinical DNA sequencing. Genet. Med. 2014, 16, 601-608. [CrossRef] [PubMed]

37. Klauke, B.; Gaertner-Rommel, A.; Schulz, U.; Kassner, A.; Zu Knyphausen, E.; Laser, T.; Kececioglu, D.; Paluszkiewicz, L.; Blanz, U.; Sandica, E.; et al. High proportion of genetic cases in patients with advanced cardiomyopathy including a novel homozygous Plakophilin 2-gene mutation. PLoS ONE 2017, 12, e0189489. [CrossRef] [PubMed]

38. Thierfelder, L.; Watkins, H.; MacRae, C.; Lamas, R.; McKenna, W.; Vosberg, H.P.; Seidman, J.G.; Seidman, C.E. Alpha-tropomyosin and cardiac troponin T mutations cause familial hypertrophic cardiomyopathy: A disease of the sarcomere. Cell 1994, 77, 701-712. [CrossRef]

39. Landstrom, A.P.; Parvatiyar, M.S.; Pinto, J.R.; Marquardt, M.L.; Bos, J.M.; Tester, D.J.; Ommen, S.R.; Potter, J.D.; Ackerman, M.J. Molecular and functional characterization of novel hypertrophic cardiomyopathy susceptibility mutations in TNNC1-encoded troponin C. J. Mol. Cell. Cardiol. 2008, 45, 281-288. [CrossRef]

40. Kimura, A.; Harada, H.; Park, J.E.; Nishi, H.; Satoh, M.; Takahashi, M.; Hiroi, S.; Sasaoka, T.; Ohbuchi, N.; Nakamura, T.; et al. Mutations in the cardiac troponin I gene associated with hypertrophic cardiomyopathy. Nat. Genet. 1997, 16, 379-382. [CrossRef]

41. Knoblauch, H.; Geier, C.; Adams, S.; Budde, B.; Rudolph, A.; Zacharias, U.; Schulz-Menger, J.; Spuler, A.; Yaou, R.B.; Nurnberg, P.; et al. Contractures and hypertrophic cardiomyopathy in a novel FHL1 mutation. Ann. Neurol. 2010, 67, 136-140. [CrossRef] [PubMed]

42. Gaertner-Rommel, A.; Tiesmeier, J.; Jakob, T.; Strickmann, B.; Veit, G.; Bachmann-Mennenga, B.; Paluszkiewicz, L.; Klingel, K.; Schulz, U.; Laser, K.T.; et al. Molecular autopsy and family screening in a young case of sudden cardiac death reveals an unusually severe case of FHL1 related hypertrophic cardiomyopathy. Mol. Genet. Genom. Med. 2019, 7, e841. [CrossRef] [PubMed]

43. Mogensen, J.; Klausen, I.C.; Pedersen, A.K.; Egeblad, H.; Bross, P.; Kruse, T.A.; Gregersen, N.; Hansen, P.S.; Baandrup, U.; Borglum, A.D. Alpha-cardiac actin is a novel disease gene in familial hypertrophic cardiomyopathy. J. Clin. Investig. 1999, 103, R39-R43. [CrossRef] [PubMed]

44. Haywood, N.J.; Wolny, M.; Rogers, B.; Trinh, C.H.; Shuping, Y.; Edwards, T.A.; Peckham, M. Hypertrophic cardiomyopathy mutations in the calponin-homology domain of ACTN2 affect actin binding and cardiomyocyte Z-disc incorporation. Biochem. J. 2016, 473, 2485-2493. [CrossRef] [PubMed]

45. Valdes-Mas, R.; Gutierrez-Fernandez, A.; Gomez, J.; Coto, E.; Astudillo, A.; Puente, D.A.; Reguero, J.R.; Alvarez, V.; Moris, C.; Leon, D.; et al. Mutations in filamin C cause a new form of familial hypertrophic cardiomyopathy. Nat. Commun. 2014, 5, 5326. [CrossRef] [PubMed]

46. Chiu, C.; Tebo, M.; Ingles, J.; Yeates, L.; Arthur, J.W.; Lind, J.M.; Semsarian, C. Genetic screening of calcium regulation genes in familial hypertrophic cardiomyopathy. J. Mol. Cell. Cardiol. 2007, 43, 337-343. [CrossRef] [PubMed]

47. Herman, D.S.; Lam, L.; Taylor, M.R.; Wang, L.; Teekakirikul, P.; Christodoulou, D.; Conner, L.; DePalma, S.R.; McDonough, B.; Sparks, E.; et al. Truncations of titin causing dilated cardiomyopathy. N. Engl. J. Med. 2012, 366, 619-628. [CrossRef] [PubMed]

48. Daehmlow, S.; Erdmann, J.; Knueppel, T.; Gille, C.; Froemmel, C.; Hummel, M.; Hetzer, R.; Regitz-Zagrosek, V. Novel mutations in sarcomeric protein genes in dilated cardiomyopathy. Biochem. Biophys. Res. Commun. 2002, 298, 116-120. [CrossRef]

49. Fatkin, D.; MacRae, C.; Sasaki, T.; Wolff, M.R.; Porcu, M.; Frenneaux, M.; Atherton, J.; Vidaillet, H.J., Jr.; Spudich, S.; De Girolami, U.; et al. Missense mutations in the rod domain of the lamin A/C gene as causes of dilated cardiomyopathy and conduction-system disease. N. Engl. J. Med. 1999, 341, 1715-1724. [CrossRef]

50. McNair, W.P.; Ku, L.; Taylor, M.R.; Fain, P.R.; Dao, D.; Wolfel, E.; Mestroni, L.; Familial cardiomyopathy registry research, G. SCN5A mutation associated with dilated cardiomyopathy, conduction disorder, and arrhythmia. Circulation 2004, 110, 2163-2167. [CrossRef]

51. Schonberger, J.; Wang, L.; Shin, J.T.; Kim, S.D.; Depreux, F.F.; Zhu, H.; Zon, L.; Pizard, A.; Kim, J.B.; Macrae, C.A.; et al. Mutation in the transcriptional coactivator EYA4 causes dilated cardiomyopathy and sensorineural hearing loss. Nat. Genet. 2005, 37, 418-422. [CrossRef] [PubMed] 
52. Brauch, K.M.; Karst, M.L.; Herron, K.J.; de Andrade, M.; Pellikka, P.A.; Rodeheffer, R.J.; Michels, V.V.; Olson, T.M. Mutations in ribonucleic acid binding protein gene cause familial dilated cardiomyopathy. J. Am. Coll. Cardiol. 2009, 54, 930-941. [CrossRef] [PubMed]

53. Hey, T.M.; Rasmussen, T.B.; Madsen, T.; Aagaard, M.M.; Harbo, M.; Molgaard, H.; Moller, J.E.; Eiskjaer, H.; Mogensen, J. Pathogenic RBM20-variants are associated with a severe disease expression in male patients with dilated cardiomyopathy. Circ. Heart Fail. 2019, 12, e005700. [CrossRef] [PubMed]

54. Nugent, A.W.; Daubeney, P.E.; Chondros, P.; Carlin, J.B.; Cheung, M.; Wilkinson, L.C.; Davis, A.M.; Kahler, S.G.; Chow, C.W.; Wilkinson, J.L.; et al. The epidemiology of childhood cardiomyopathy in Australia. N. Engl. J. Med. 2003, 348, 1639-1646. [CrossRef] [PubMed]

55. Jefferies, J.L.; Wilkinson, J.D.; Sleeper, L.A.; Colan, S.D.; Lu, M.; Pahl, E.; Kantor, P.F.; Everitt, M.D.; Webber, S.A.; Kaufman, B.D.; et al. Pediatric cardiomyopathy registry, I. Cardiomyopathy phenotypes and outcomes for children with left ventricular myocardial noncompaction: Results from the pediatric cardiomyopathy registry. J. Card. Fail. 2015, 21, 877-884. [CrossRef] [PubMed]

56. Marziliano, N.; Mannarino, S.; Nespoli, L.; Diegoli, M.; Pasotti, M.; Malattia, C.; Grasso, M.; Pilotto, A.; Porcu, E.; Raisaro, A.; et al. Barth syndrome associated with compound hemizygosity and heterozygosity of the TAZ and LDB3 genes. Am. J. Med. Genet. Part A 2007, 143A, 907-915. [CrossRef] [PubMed]

57. Probst, S.; Oechslin, E.; Schuler, P.; Greutmann, M.; Boye, P.; Knirsch, W.; Berger, F.; Thierfelder, L.; Jenni, R.; Klaassen, S. Sarcomere gene mutations in isolated left ventricular noncompaction cardiomyopathy do not predict clinical phenotype. Circ. Cardiovasc. Genet. 2011, 4, 367-374. [CrossRef] [PubMed]

58. McKoy, G.; Protonotarios, N.; Crosby, A.; Tsatsopoulou, A.; Anastasakis, A.; Coonar, A.; Norman, M.; Baboonian, C.; Jeffery, S.; McKenna, W.J. Identification of a deletion in plakoglobin in arrhythmogenic right ventricular cardiomyopathy with palmoplantar keratoderma and woolly hair (Naxos disease). Lancet 2000, 355, 2119-2124. [CrossRef]

59. Gerull, B.; Heuser, A.; Wichter, T.; Paul, M.; Basson, C.T.; McDermott, D.A.; Lerman, B.B.; Markowitz, S.M.; Ellinor, P.T.; MacRae, C.A.; et al. Mutations in the desmosomal protein plakophilin-2 are common in arrhythmogenic right ventricular cardiomyopathy. Nat. Genet. 2004, 36, 1162-1164. [CrossRef]

60. Patel, D.M.; Green, K.J. Desmosomes in the heart: A review of clinical and mechanistic analyses. Cell Commun. Adhes. 2014, 21, 109-128. [CrossRef]

61. Xu, T.; Yang, Z.; Vatta, M.; Rampazzo, A.; Beffagna, G.; Pilichou, K.; Scherer, S.E.; Saffitz, J.; Kravitz, J.; Zareba, W.; et al. Multidisciplinary study of right ventricular dysplasia, I. Compound and digenic heterozygosity contributes to arrhythmogenic right ventricular cardiomyopathy. J. Am. Coll. Cardiol. 2010, 55, 587-597. [CrossRef] [PubMed]

62. Brodehl, A.; Hedde, P.N.; Dieding, M.; Fatima, A.; Walhorn, V.; Gayda, S.; Saric, T.; Klauke, B.; Gummert, J.; Anselmetti, D.; et al. Dual color photoactivation localization microscopy of cardiomyopathy-associated desmin mutants. J. Biol. Chem. 2012, 287, 16047-16057. [CrossRef] [PubMed]

63. Quarta, G.; Syrris, P.; Ashworth, M.; Jenkins, S.; Zuborne Alapi, K.; Morgan, J.; Muir, A.; Pantazis, A.; McKenna, W.J.; Elliott, P.M. Mutations in the Lamin A/C gene mimic arrhythmogenic right ventricular cardiomyopathy. Eur. Heart J. 2012, 33, 1128-1136. [CrossRef] [PubMed]

64. Abdelfatah, N.; Chen, R.; Duff, H.J.; Seifer, C.M.; Buffo, I.; Huculak, C.; Clarke, S.; Clegg, R.; Jassal, D.S.; Gordon, P.M.K.; et al. Characterization of a unique form of arrhythmic cardiomyopathy caused by recessive mutation in LEMD2. JACC Basic Transl. Sci. 2019, 4, 204-221. [CrossRef] [PubMed]

65. Tiso, N.; Stephan, D.A.; Nava, A.; Bagattin, A.; Devaney, J.M.; Stanchi, F.; Larderet, G.; Brahmbhatt, B.; Brown, K.; Bauce, B.; et al. Identification of mutations in the cardiac ryanodine receptor gene in families affected with arrhythmogenic right ventricular cardiomyopathy type 2 (ARVD2). Hum. Mol. Genet. 2001, 10, 189-194. [CrossRef] [PubMed]

66. Milting, H.; Lukas, N.; Klauke, B.; Korfer, R.; Perrot, A.; Osterziel, K.J.; Vogt, J.; Peters, S.; Thieleczek, R.; Varsanyi, M. Composite polymorphisms in the ryanodine receptor 2 gene associated with arrhythmogenic right ventricular cardiomyopathy. Cardiovasc. Res. 2006, 71, 496-505. [CrossRef] [PubMed]

67. Van der Zwaag, P.A.; van Rijsingen, I.A.; Asimaki, A.; Jongbloed, J.D.; van Veldhuisen, D.J.; Wiesfeld, A.C.; Cox, M.G.; van Lochem, L.T.; de Boer, R.A.; Hofstra, R.M.; et al. Phospholamban R14del mutation in patients diagnosed with dilated cardiomyopathy or arrhythmogenic right ventricular cardiomyopathy: Evidence supporting the concept of arrhythmogenic cardiomyopathy. Eur. J. Heart Fail. 2012, 14, 1199-1207. [CrossRef] 
68. Brodehl, A.; Rezazadeh, S.; Williams, T.; Munsie, N.M.; Liedtke, D.; Oh, T.; Ferrier, R.; Shen, Y.; Jones, S.J.M.; Stiegler, A.L.; et al. Mutations in ILK, encoding integrin-linked kinase, are associated with arrhythmogenic cardiomyopathy. Transl. Res. 2019, 208, 15-29. [CrossRef]

69. Kostareva, A.; Kiselev, A.; Gudkova, A.; Frishman, G.; Ruepp, A.; Frishman, D.; Smolina, N.; Tarnovskaya, S.; Nilsson, D.; Zlotina, A.; et al. Genetic spectrum of idiopathic restrictive cardiomyopathy uncovered by next-generation sequencing. PLoS ONE 2016, 11, e0163362. [CrossRef]

70. Gallego-Delgado, M.; Delgado, J.F.; Brossa-Loidi, V.; Palomo, J.; Marzoa-Rivas, R.; Perez-Villa, F.; Salazar-Mendiguchia, J.; Ruiz-Cano, M.J.; Gonzalez-Lopez, E.; Padron-Barthe, L.; et al. Idiopathic restrictive cardiomyopathy Is primarily a genetic disease. J. Am. Coll. Cardiol. 2016, 67, 3021-3023. [CrossRef]

71. Mogensen, J.; Kubo, T.; Duque, M.; Uribe, W.; Shaw, A.; Murphy, R.; Gimeno, J.R.; Elliott, P.; McKenna, W.J. Idiopathic restrictive cardiomyopathy is part of the clinical expression of cardiac troponin I mutations. J. Clin. Investig. 2003, 111, 209-216. [CrossRef] [PubMed]

72. Brodehl, A.; Ferrier, R.A.; Hamilton, S.J.; Greenway, S.C.; Brundler, M.A.; Yu, W.; Gibson, W.T.; McKinnon, M.L.; McGillivray, B.; Alvarez, N.; et al. Mutations in FLNC are associated with familial restrictive cardiomyopathy. Hum. Mutat. 2016, 37, 269-279. [CrossRef] [PubMed]

73. Tucker, N.R.; McLellan, M.A.; Hu, D.; Ye, J.; Parsons, V.A.; Mills, R.W.; Clauss, S.; Dolmatova, E.; Shea, M.A.; Milan, D.J.; et al. Novel mutation in FLNC (Filamin C) causes familial restrictive cardiomyopathy. Circ. Cardiovasc. Genet. 2017, 10, e001780. [CrossRef] [PubMed]

74. Kiselev, A.; Vaz, R.; Knyazeva, A.; Khudiakov, A.; Tarnovskaya, S.; Liu, J.; Sergushichev, A.; Kazakov, S.; Frishman, D.; Smolina, N.; et al. De novo mutations in FLNC leading to early-onset restrictive cardiomyopathy and congenital myopathy. Hum. Mutat. 2018, 39, 1161-1172. [CrossRef] [PubMed]

75. Schubert, J.; Tariq, M.; Geddes, G.; Kindel, S.; Miller, E.M.; Ware, S.M. Novel pathogenic variants in filamin C identified in pediatric restrictive cardiomyopathy. Hum. Mutat. 2018, 39, 2083-2096. [CrossRef] [PubMed]

76. Roldan-Sevilla, A.; Palomino-Doza, J.; de Juan, J.; Sanchez, V.; Dominguez-Gonzalez, C.; Salguero-Bodes, R.; Arribas-Ynsaurriaga, F. Missense mutations in the FLNC gene causing familial restrictive cardiomyopathy. Circ. Genom. Precis. Med. 2019, 12, e002388. [CrossRef]

77. Bienengraeber, M.; Olson, T.M.; Selivanov, V.A.; Kathmann, E.C.; O'Cochlain, F.; Gao, F.; Karger, A.B.; Ballew, J.D.; Hodgson, D.M.; Zingman, L.V.; et al. ABCC9 mutations identified in human dilated cardiomyopathy disrupt catalytic KATP channel gating. Nat. Genet. 2004, 36, 382-387. [CrossRef]

78. Collet, M.; Assouline, Z.; Bonnet, D.; Rio, M.; Iserin, F.; Sidi, D.; Goldenberg, A.; Lardennois, C.; Metodiev, M.D.; Haberberger, B.; et al. High incidence and variable clinical outcome of cardiac hypertrophy due to ACAD9 mutations in childhood. Eur. J. Hum. Genet. 2016, 24, 1112-1116. [CrossRef]

79. Carlus, S.J.; Almuzaini, I.S.; Karthikeyan, M.; Loganathan, L.; Al-Harbi, G.S.; Abdallah, A.M.; Al-Harbi, K.M. Next-generation sequencing identifies a homozygous mutation in ACADVL associated with pediatric familial dilated cardiomyopathy. Eur. Rev. Med. Pharmacol. Sci. 2019, 23, 1710-1721.

80. Monserrat, L.; Hermida-Prieto, M.; Fernandez, X.; Rodriguez, I.; Dumont, C.; Cazon, L.; Cuesta, M.G.; Gonzalez-Juanatey, C.; Peteiro, J.; Alvarez, N.; et al. Mutation in the alpha-cardiac actin gene associated with apical hypertrophic cardiomyopathy, left ventricular non-compaction, and septal defects. Eur. Heart J. 2007, 28, 1953-1961. [CrossRef]

81. Olson, T.M.; Michels, V.V.; Thibodeau, S.N.; Tai, Y.S.; Keating, M.T. Actin mutations in dilated cardiomyopathy, a heritable form of heart failure. Science 1998, 280, 750-752. [CrossRef] [PubMed]

82. Klaassen, S.; Probst, S.; Oechslin, E.; Gerull, B.; Krings, G.; Schuler, P.; Greutmann, M.; Hurlimann, D.; Yegitbasi, M.; Pons, L.; et al. Mutations in sarcomere protein genes in left ventricular noncompaction. Circulation 2008, 117, 2893-2901. [CrossRef] [PubMed]

83. Kaski, J.P.; Syrris, P.; Burch, M.; Tome-Esteban, M.T.; Fenton, M.; Christiansen, M.; Andersen, P.S.; Sebire, N.; Ashworth, M.; Deanfield, J.E.; et al. Idiopathic restrictive cardiomyopathy in children is caused by mutations in cardiac sarcomere protein genes. Heart 2008, 94, 1478-1484. [CrossRef] [PubMed]

84. Chiu, C.; Bagnall, R.D.; Ingles, J.; Yeates, L.; Kennerson, M.; Donald, J.A.; Jormakka, M.; Lind, J.M.; Semsarian, C. Mutations in alpha-actinin-2 cause hypertrophic cardiomyopathy: A genome-wide analysis. J. Am. Coll. Cardiol. 2010, 55, 1127-1135. [CrossRef] [PubMed]

85. Mohapatra, B.; Jimenez, S.; Lin, J.H.; Bowles, K.R.; Coveler, K.J.; Marx, J.G.; Chrisco, M.A.; Murphy, R.T.; Lurie, P.R.; Schwartz, R.J.; et al. Mutations in the muscle LIM protein and alpha-actinin-2 genes in dilated cardiomyopathy and endocardial fibroelastosis. Mol. Genet. Metab. 2003, 80, 207-215. [CrossRef] 
86. Bagnall, R.D.; Molloy, L.K.; Kalman, J.M.; Semsarian, C. Exome sequencing identifies a mutation in the ACTN2 gene in a family with idiopathic ventricular fibrillation, left ventricular noncompaction, and sudden death. BMC Med. Genet. 2014, 15, 99. [CrossRef] [PubMed]

87. Waldmuller, S.; Schroeder, C.; Sturm, M.; Scheffold, T.; Imbrich, K.; Junker, S.; Frische, C.; Hofbeck, M.; Bauer, P.; Bonin, M.; et al. Targeted 46-gene and clinical exome sequencing for mutations causing cardiomyopathies. Mol. Cell. Probes 2015, 29, 308-314. [CrossRef] [PubMed]

88. Forleo, C.; D’Erchia, A.M.; Sorrentino, S.; Manzari, C.; Chiara, M.; Iacoviello, M.; Guaricci, A.I.; De Santis, D.; Musci, R.L.; La Spada, A.; et al. Targeted next-generation sequencing detects novel gene-phenotype associations and expands the mutational spectrum in cardiomyopathies. PLoS ONE 2017, 12, e0181842. [CrossRef] [PubMed]

89. Nerakh, G.; Ranganath, P. Alstrom syndrome presenting as isolated dilated cardiomyopathy. Indian J. Pediatr. 2019, 86, 296-298. [CrossRef]

90. Almomani, R.; Verhagen, J.M.; Herkert, J.C.; Brosens, E.; van Spaendonck-Zwarts, K.Y.; Asimaki, A.; van der Zwaag, P.A.; Frohn-Mulder, I.M.; Bertoli-Avella, A.M.; Boven, L.G.; et al. Biallelic truncating mutations in ALPK3 cause severe pediatric cardiomyopathy. J. Am. Coll. Cardiol. 2016, 67, 515-525. [CrossRef]

91. Lopes, L.R.; Syrris, P.; Guttmann, O.P.; O’Mahony, C.; Tang, H.C.; Dalageorgou, C.; Jenkins, S.; Hubank, M.; Monserrat, L.; McKenna, W.J.; et al. Novel genotype-phenotype associations demonstrated by high-throughput sequencing in patients with hypertrophic cardiomyopathy. Heart 2015, 101, $294-301$. [CrossRef] [PubMed]

92. Roberts, J.D.; Murphy, N.P.; Hamilton, R.M.; Lubbers, E.R.; James, C.A.; Kline, C.F.; Gollob, M.H.; Krahn, A.D.; Sturm, A.C.; Musa, H.; et al. Ankyrin-B dysfunction predisposes to arrhythmogenic cardiomyopathy and is amenable to therapy. J. Clin. Investig. 2019, 129, 3171-3184. [CrossRef] [PubMed]

93. Arimura, T.; Bos, J.M.; Sato, A.; Kubo, T.; Okamoto, H.; Nishi, H.; Harada, H.; Koga, Y.; Moulik, M.; Doi, Y.L.; et al. Cardiac ankyrin repeat protein gene (ANKRD1) mutations in hypertrophic cardiomyopathy. J. Am. Coll. Cardiol. 2009, 54, 334-342. [CrossRef] [PubMed]

94. Duboscq-Bidot, L.; Charron, P.; Ruppert, V.; Fauchier, L.; Richter, A.; Tavazzi, L.; Arbustini, E.; Wichter, T.; Maisch, B.; Komajda, M.; et al. Mutations in the ANKRD1 gene encoding CARP are responsible for human dilated cardiomyopathy. Eur. Heart J. 2009, 30, 2128-2136. [CrossRef] [PubMed]

95. Moulik, M.; Vatta, M.; Witt, S.H.; Arola, A.M.; Murphy, R.T.; McKenna, W.J.; Boriek, A.M.; Oka, K.; Labeit, S.; Bowles, N.E.; et al. ANKRD1, the gene encoding cardiac ankyrin repeat protein, is a novel dilated cardiomyopathy gene. J. Am. Coll. Cardiol. 2009, 54, 325-333. [CrossRef] [PubMed]

96. Norton, N.; Li, D.; Rieder, M.J.; Siegfried, J.D.; Rampersaud, E.; Zuchner, S.; Mangos, S.; Gonzalez-Quintana, J.; Wang, L.; McGee, S.; et al. Genome-wide studies of copy number variation and exome sequencing identify rare variants in BAG3 as a cause of dilated cardiomyopathy. Am. J. Hum. Genet. 2011, 88, 273-282. [CrossRef] [PubMed]

97. Schanzer, A.; Rupp, S.; Graf, S.; Zengeler, D.; Jux, C.; Akinturk, H.; Gulatz, L.; Mazhari, N.; Acker, T.; Van Coster, R.; et al. Dysregulated autophagy in restrictive cardiomyopathy due to Pro209Leu mutation in BAG3. Mol. Genet. Metab. 2018, 123, 388-399. [CrossRef] [PubMed]

98. Gripp, K.W.; Lin, A.E.; Nicholson, L.; Allen, W.; Cramer, A.; Jones, K.L.; Kutz, W.; Peck, D.; Rebolledo, M.A.; Wheeler, P.G.; et al. Further delineation of the phenotype resulting from BRAF or MEK1 germline mutations helps differentiate cardio-facio-cutaneous syndrome from Costello syndrome. Am. J. Med. Genet. Part A 2007, 143A, 1472-1480. [CrossRef] [PubMed]

99. Shakeel, M.; Irfan, M.; Khan, I.A. Rare genetic mutations in Pakistani patients with dilated cardiomyopathy. Gene 2018, 673, 134-139. [CrossRef]

100. Boczek, N.J.; Ye, D.; Jin, F.; Tester, D.J.; Huseby, A.; Bos, J.M.; Johnson, A.J.; Kanter, R.; Ackerman, M.J. Identification and functional characterization of a novel CACNA1C-mediated cardiac disorder characterized by prolonged QT intervals with hypertrophic cardiomyopathy, congenital heart defects, and sudden cardiac death. Circ. Arrhythm. Electrophysiol. 2015, 8, 1122-1132. [CrossRef]

101. Friedrich, F.W.; Bausero, P.; Sun, Y.; Treszl, A.; Kramer, E.; Juhr, D.; Richard, P.; Wegscheider, K.; Schwartz, K.; Brito, D.; et al. A new polymorphism in human calmodulin III gene promoter is a potential modifier gene for familial hypertrophic cardiomyopathy. Eur. Heart J. 2009, 30, 1648-1655. [CrossRef] [PubMed] 
102. Qiu, X.B.; Qu, X.K.; Li, R.G.; Liu, H.; Xu, Y.J.; Zhang, M.; Shi, H.Y.; Hou, X.M.; Liu, X.; Yuan, F.; et al. CASZ1 loss-of-function mutation contributes to familial dilated cardiomyopathy. Clin. Chem. Lab. Med. 2017, 55, 1417-1425. [CrossRef] [PubMed]

103. Guo, J.; Li, Z.; Hao, C.; Guo, R.; Hu, X.; Qian, S.; Zeng, J.; Gao, H.; Li, W. A novel de novo CASZ1 heterozygous frameshift variant causes dilated cardiomyopathy and left ventricular noncompaction cardiomyopathy. Mol. Genet. Genom. Med. 2019, 7, e828. [CrossRef] [PubMed]

104. Hayashi, T.; Arimura, T.; Ueda, K.; Shibata, H.; Hohda, S.; Takahashi, M.; Hori, H.; Koga, Y.; Oka, N.; Imaizumi, T.; et al. Identification and functional analysis of a caveolin-3 mutation associated with familial hypertrophic cardiomyopathy. Biochem. Biophys. Res. Commun. 2004, 313, 178-184. [CrossRef] [PubMed]

105. Rodriguez, G.; Ueyama, T.; Ogata, T.; Czernuszewicz, G.; Tan, Y.; Dorn, G.W., II; Bogaev, R.; Amano, K.; Oh, H.; Matsubara, H.; et al. Molecular genetic and functional characterization implicate muscle-restricted coiled-coil gene (MURC) as a causal gene for familial dilated cardiomyopathy. Circ. Cardiovasc. Genet. 2011, 4, 349-358. [CrossRef] [PubMed]

106. Mayosi, B.M.; Fish, M.; Shaboodien, G.; Mastantuono, E.; Kraus, S.; Wieland, T.; Kotta, M.C.; Chin, A.; Laing, N.; Ntusi, N.B.; et al. Identification of Cadherin $2(\mathrm{CDH} 2)$ mutations in arrhythmogenic right ventricular cardiomyopathy. Circ. Cardiovasc. Genet. 2017, 10, e001605. [CrossRef]

107. Turkowski, K.L.; Tester, D.J.; Bos, J.M.; Haugaa, K.H.; Ackerman, M.J. Whole exome sequencing with genomic triangulation implicates $\mathrm{CDH}$ 2-encoded $\mathrm{N}$-cadherin as a novel pathogenic substrate for arrhythmogenic cardiomyopathy. Congenit. Heart Dis. 2017, 12, 226-235. [CrossRef]

108. Zhang, L.; Hu, A.; Yuan, H.; Cui, L.; Miao, G.; Yang, X.; Wang, L.; Liu, J.; Liu, X.; Wang, S.; et al. A missense mutation in the CHRM2 gene is associated with familial dilated cardiomyopathy. Circ. Res. 2008, 102, 1426-1432. [CrossRef]

109. Lan, N.S.R.; Fietz, M.; Pachter, N.; Paul, V.; Playford, D. A case of vascular Ehlers-Danlos Syndrome with a cardiomyopathy and multi-system involvement. Cardiovasc. Pathol. 2018, 35, 48-51. [CrossRef]

110. Antonicka, H.; Mattman, A.; Carlson, C.G.; Glerum, D.M.; Hoffbuhr, K.C.; Leary, S.C.; Kennaway, N.G.; Shoubridge, E.A. Mutations in COX15 produce a defect in the mitochondrial heme biosynthetic pathway, causing early-onset fatal hypertrophic cardiomyopathy. Am. J. Hum. Genet. 2003, 72, 101-114. [CrossRef]

111. Inagaki, N.; Hayashi, T.; Arimura, T.; Koga, Y.; Takahashi, M.; Shibata, H.; Teraoka, K.; Chikamori, T.; Yamashina, A.; Kimura, A. $\alpha$ B-crystallin mutation in dilated cardiomyopathy. Biochem. Biophys. Res. Commun. 2006, 342, 379-386. [CrossRef] [PubMed]

112. Brodehl, A.; Gaertner-Rommel, A.; Klauke, B.; Grewe, S.A.; Schirmer, I.; Peterschroder, A.; Faber, L.; Vorgerd, M.; Gummert, J.; Anselmetti, D.; et al. The novel $\alpha$ B-crystallin (CRYAB) mutation p.D109G causes restrictive cardiomyopathy. Hum. Mutat. 2017, 38, 947-952. [CrossRef] [PubMed]

113. Newman, B.; Cescon, D.; Woo, A.; Rakowski, H.; Erikkson, M.J.; Sole, M.; Wigle, E.D.; Siminovitch, K.A. W4R variant in CSRP3 encoding muscle LIM protein in a patient with hypertrophic cardiomyopathy. Mol. Genet. Metab. 2005, 84, 374-375. [CrossRef] [PubMed]

114. Geier, C.; Gehmlich, K.; Ehler, E.; Hassfeld, S.; Perrot, A.; Hayess, K.; Cardim, N.; Wenzel, K.; Erdmann, B.; Krackhardt, F.; et al. Beyond the sarcomere: CSRP3 mutations cause hypertrophic cardiomyopathy. Hum. Mol. Genet. 2008, 17, 2753-2765. [CrossRef] [PubMed]

115. Janin, A.; Bessiere, F.; Chauveau, S.; Chevalier, P.; Millat, G. First identification of homozygous truncating CSRP3 variants in two unrelated cases with hypertrophic cardiomyopathy. Gene 2018, 676, 110-116. [CrossRef]

116. Hershberger, R.E.; Parks, S.B.; Kushner, J.D.; Li, D.; Ludwigsen, S.; Jakobs, P.; Nauman, D.; Burgess, D.; Partain, J.; Litt, M. Coding sequence mutations identified in MYH7, TNNT2, SCN5A, CSRP3, LBD3, and TCAP from 313 patients with familial or idiopathic dilated cardiomyopathy. Clin. Transl. Sci. 2008, 1, 21-26. [CrossRef] [PubMed]

117. Erdmann, J.; Hassfeld, S.; Kallisch, H.; Fleck, E.; Regitz-Zagrose, V. Genetic variants in the promoter (g983G $>$ T) and coding region (A92T) of the human cardiotrophin-1 gene (CTF1) in patients with dilated cardiomyopathy. Hum. Mutat. 2000, 16, 448. [CrossRef]

118. Van Hengel, J.; Calore, M.; Bauce, B.; Dazzo, E.; Mazzotti, E.; De Bortoli, M.; Lorenzon, A.; Li Mura, I.E.; Beffagna, G.; Rigato, I.; et al. Mutations in the area composita protein alphaT-catenin are associated with arrhythmogenic right ventricular cardiomyopathy. Eur. Heart J. 2013, 34, 201-210. [CrossRef] 
119. Taylor, M.R.; Slavov, D.; Ku, L.; Di Lenarda, A.; Sinagra, G.; Carniel, E.; Haubold, K.; Boucek, M.M.; Ferguson, D.; Graw, S.L.; et al. Prevalence of desmin mutations in dilated cardiomyopathy. Circulation 2007, 115, 1244-1251. [CrossRef]

120. Towbin, J.A.; Hejtmancik, J.F.; Brink, P.; Gelb, B.; Zhu, X.M.; Chamberlain, J.S.; McCabe, E.R.; Swift, M. $\mathrm{X}$-linked dilated cardiomyopathy. Molecular genetic evidence of linkage to the Duchenne muscular dystrophy (dystrophin) gene at the Xp21 locus. Circulation 1993, 87, 1854-1865. [CrossRef]

121. Ojala, T.; Polinati, P.; Manninen, T.; Hiippala, A.; Rajantie, J.; Karikoski, R.; Suomalainen, A.; Tyni, T. New mutation of mitochondrial DNAJC19 causing dilated and noncompaction cardiomyopathy, anemia, ataxia, and male genital anomalies. Pediatr. Res. 2012, 72, 432-437. [CrossRef] [PubMed]

122. Rush, E.T.; Baker, C.V.; Rizzo, W.B. Dolichol kinase deficiency (DOLK-CDG): Two new cases and expansion of phenotype. Am. J. Med. Genet. Part A 2017, 173, 2428-2434. [CrossRef] [PubMed]

123. Svahn, J.; Laforet, P.; Vial, C.; Streichenberger, N.; Romero, N.; Bouchet-Seraphin, C.; Bruneel, A.; Dupre, T.; Seta, N.; Menassa, R.; et al. Dilated cardiomyopathy and limb-girdle muscular dystrophy-dystroglycanopathy due to novel pathogenic variants in the DPM3 gene. Neuromuscul. Disord. 2019, 29, 497-502. [CrossRef] [PubMed]

124. Heuser, A.; Plovie, E.R.; Ellinor, P.T.; Grossmann, K.S.; Shin, J.T.; Wichter, T.; Basson, C.T.; Lerman, B.B.; Sasse-Klaassen, S.; Thierfelder, L.; et al. Mutant desmocollin-2 causes arrhythmogenic right ventricular cardiomyopathy. Am. J. Hum. Genet. 2006, 79, 1081-1088. [CrossRef] [PubMed]

125. Posch, M.G.; Posch, M.J.; Geier, C.; Erdmann, B.; Mueller, W.; Richter, A.; Ruppert, V.; Pankuweit, S.; Maisch, B.; Perrot, A.; et al. A missense variant in desmoglein-2 predisposes to dilated cardiomyopathy. Mol. Genet. Metab. 2008, 95, 74-80. [CrossRef]

126. Awad, M.M.; Dalal, D.; Cho, E.; Amat-Alarcon, N.; James, C.; Tichnell, C.; Tucker, A.; Russell, S.D.; Bluemke, D.A.; Dietz, H.C.; et al. DSG2 mutations contribute to arrhythmogenic right ventricular dysplasia/cardiomyopathy. Am. J. Hum. Genet. 2006, 79, 136-142. [CrossRef] [PubMed]

127. Pilichou, K.; Nava, A.; Basso, C.; Beffagna, G.; Bauce, B.; Lorenzon, A.; Frigo, G.; Vettori, A.; Valente, M.; Towbin, J.; et al. Mutations in desmoglein-2 gene are associated with arrhythmogenic right ventricular cardiomyopathy. Circulation 2006, 113, 1171-1179. [CrossRef]

128. Norgett, E.E.; Hatsell, S.J.; Carvajal-Huerta, L.; Cabezas, J.C.; Common, J.; Purkis, P.E.; Whittock, N.; Leigh, I.M.; Stevens, H.P.; Kelsell, D.P. Recessive mutation in desmoplakin disrupts desmoplakin-intermediate filament interactions and causes dilated cardiomyopathy, woolly hair and keratoderma. Hum. Mol. Genet. 2000, 9, 2761-2766. [CrossRef]

129. Williams, T.; Machann, W.; Kuhler, L.; Hamm, H.; Muller-Hocker, J.; Zimmer, M.; Ertl, G.; Ritter, O.; Beer, M.; Schonberger, J. Novel desmoplakin mutation: Juvenile biventricular cardiomyopathy with left ventricular non-compaction and acantholytic palmoplantar keratoderma. Clin. Res. Cardiol. 2011, 100, 1087-1093. [CrossRef]

130. Rampazzo, A.; Nava, A.; Malacrida, S.; Beffagna, G.; Bauce, B.; Rossi, V.; Zimbello, R.; Simionati, B.; Basso, C.; Thiene, G.; et al. Mutation in human desmoplakin domain binding to plakoglobin causes a dominant form of arrhythmogenic right ventricular cardiomyopathy. Am. J. Hum. Genet. 2002, 71, 1200-1206. [CrossRef]

131. Cao, Q.; Shen, Y.; Liu, X.; Yu, X.; Yuan, P.; Wan, R.; Liu, X.; Peng, X.; He, W.; Pu, J.; et al. Phenotype and functional analyses in a transgenic mouse model of left ventricular noncompaction caused by a DTNA mutation. Int. Heart J. 2017, 58, 939-947. [CrossRef] [PubMed]

132. Haack, T.B.; Kopajtich, R.; Freisinger, P.; Wieland, T.; Rorbach, J.; Nicholls, T.J.; Baruffini, E.; Walther, A.; Danhauser, K.; Zimmermann, F.A.; et al. ELAC2 mutations cause a mitochondrial RNA processing defect associated with hypertrophic cardiomyopathy. Am. J. Hum. Genet. 2013, 93, 211-223. [CrossRef] [PubMed]

133. Zhang, M.; Chen, J.; Si, D.; Zheng, Y.; Jiao, H.; Feng, Z.; Hu, Z.; Duan, R. Whole exome sequencing identifies a novel EMD mutation in a Chinese family with dilated cardiomyopathy. BMC Med. Genet. 2014, 15, 77. [CrossRef] [PubMed]

134. Tang, S.; Hoshida, H.; Kamisago, M.; Yagi, H.; Momma, K.; Matsuoka, R. Phenotype-genotype correlation in a patient with co-occurrence of Marfan and LEOPARD syndromes. Am. J. Med. Genet. Part A 2009, 149A, 2216-2219. [CrossRef] [PubMed]

135. Jacobs, A.M.; Toudjarska, I.; Racine, A.; Tsipouras, P.; Kilpatrick, M.W.; Shanske, A. A recurring FBN1 gene mutation in neonatal Marfan syndrome. Arch. Pediatr. Adolesc. Med. 2002, 156, 1081-1085. [CrossRef] [PubMed] 
136. Parent, J.J.; Towbin, J.A.; Jefferies, J.L. Fibrillin-1 gene mutations in left ventricular non-compaction cardiomyopathy. Pediatr. Cardiol. 2016, 37, 1123-1126. [CrossRef]

137. Al-Yacoub, N.; Shaheen, R.; Awad, S.M.; Kunhi, M.; Dzimiri, N.; Nguyen, H.C.; Xiong, Y.; Al-Buraiki, J.; Al-Habeeb, W.; Alkuraya, F.S.; et al. FBXO32, encoding a member of the SCF complex, is mutated in dilated cardiomyopathy. Genome Biol. 2016, 17, 2. [CrossRef]

138. Al-Hassnan, Z.N.; Shinwari, Z.M.; Wakil, S.M.; Tulbah, S.; Mohammed, S.; Rahbeeni, Z.; Alghamdi, M.; Rababh, M.; Colak, D.; Kaya, N.; et al. A substitution mutation in cardiac ubiquitin ligase, FBXO32, is associated with an autosomal recessive form of dilated cardiomyopathy. BMC Med. Genet. 2016, 17, 3. [CrossRef] [PubMed]

139. Arimura, T.; Hayashi, T.; Matsumoto, Y.; Shibata, H.; Hiroi, S.; Nakamura, T.; Inagaki, N.; Hinohara, K.; Takahashi, M.; Manatsu, S.I.; et al. Structural analysis of four and half LIM protein-2 in dilated cardiomyopathy. Biochem. Biophys. Res. Commun. 2007, 357, 162-167. [CrossRef]

140. Ochoa, J.P.; Sabater-Molina, M.; Garcia-Pinilla, J.M.; Mogensen, J.; Restrepo-Cordoba, A.; Palomino-Doza, J.; Villacorta, E.; Martinez-Moreno, M.; Ramos-Maqueda, J.; Zorio, E.; et al. Formin Homology 2 Domain Containing 3 (FHOD3) Is a genetic basis for hypertrophic cardiomyopathy. J. Am. Coll. Cardiol. 2018, 72, 2457-2467. [CrossRef]

141. Arimura, T.; Takeya, R.; Ishikawa, T.; Yamano, T.; Matsuo, A.; Tatsumi, T.; Nomura, T.; Sumimoto, H.; Kimura, A. Dilated cardiomyopathy-associated FHOD3 variant impairs the ability to induce activation of transcription factor serum response factor. Circ. J. 2013, 77, 2990-2996. [CrossRef] [PubMed]

142. Muller, T.; Krasnianski, M.; Witthaut, R.; Deschauer, M.; Zierz, S. Dilated cardiomyopathy may be an early sign of the C826A Fukutin-related protein mutation. Neuromuscul. Disord. 2005, 15, 372-376. [CrossRef] [PubMed]

143. Amiya, E.; Morita, H.; Hatano, M.; Nitta, D.; Hosoya, Y.; Maki, H.; Motozawa, Y.; Sato, N.; Ishiura, H.; Numakura, S.; et al. Fukutin gene mutations that cause left ventricular noncompaction. Int. J. Cardiol. 2016, 222, 727-729. [CrossRef] [PubMed]

144. Begay, R.L.; Tharp, C.A.; Martin, A.; Graw, S.L.; Sinagra, G.; Miani, D.; Sweet, M.E.; Slavov, D.B.; Stafford, N.; Zeller, M.J.; et al. FLNC gene splice mutations cause dilated cardiomyopathy. JACC Basic Transl. Sci. 2016, 1, 344-359. [CrossRef] [PubMed]

145. Ortiz-Genga, M.F.; Cuenca, S.; Dal Ferro, M.; Zorio, E.; Salgado-Aranda, R.; Climent, V.; Padron-Barthe, L.; Duro-Aguado, I.; Jimenez-Jaimez, J.; Hidalgo-Olivares, V.M.; et al. Truncating FLNC mutations are associated with high-risk dilated and arrhythmogenic cardiomyopathies. J. Am. Coll. Cardiol. 2016, 68, 2440-2451. [CrossRef] [PubMed]

146. Minoretti, P.; Arra, M.; Emanuele, E.; Olivieri, V.; Aldeghi, A.; Politi, P.; Martinelli, V.; Pesenti, S.; Falcone, C. A W148R mutation in the human FOXD4 gene segregating with dilated cardiomyopathy, obsessive-compulsive disorder, and suicidality. Int. J. Mol. Med. 2007, 19, 369-372. [CrossRef]

147. Payne, R.M.; Wagner, G.R. Cardiomyopathy in Friedreich ataxia: Clinical findings and research. J. Child Neurol. 2012, 27, 1179-1186. [CrossRef]

148. Campuzano, V.; Montermini, L.; Molto, M.D.; Pianese, L.; Cossee, M.; Cavalcanti, F.; Monros, E.; Rodius, F.; Duclos, F.; Monticelli, A.; et al. Friedreich's ataxia: Autosomal recessive disease caused by an intronic GAA triplet repeat expansion. Science 1996, 271, 1423-1427. [CrossRef]

149. Li, R.G.; Li, L.; Qiu, X.B.; Yuan, F.; Xu, L.; Li, X.; Xu, Y.J.; Jiang, W.F.; Jiang, J.Q.; Liu, X.; et al. GATA4 loss-of-function mutation underlies familial dilated cardiomyopathy. Biochem. Biophys. Res. Commun. 2013, 439, 591-596. [CrossRef]

150. Tang, V.T.; Arscott, P.; Helms, A.S.; Day, S.M. Whole-exome sequencing reveals GATA4 and PTEN mutations as a potential digenic cause of left ventricular noncompaction. Circ. Genom. Precis. Med. 2018, 11, e001966. [CrossRef]

151. Zhang, X.L.; Dai, N.; Tang, K.; Chen, Y.Q.; Chen, W.; Wang, J.; Zhao, C.M.; Yuan, F.; Qiu, X.B.; Qu, X.K.; et al. GATA5 loss-of-function mutation in familial dilated cardiomyopathy. Int. J. Mol. Med. 2015, 35, 763-770. [CrossRef] [PubMed]

152. Theis, J.L.; Sharpe, K.M.; Matsumoto, M.E.; Chai, H.S.; Nair, A.A.; Theis, J.D.; de Andrade, M.; Wieben, E.D.; Michels, V.V.; Olson, T.M. Homozygosity mapping and exome sequencing reveal GATAD1 mutation in autosomal recessive dilated cardiomyopathy. Circ. Cardiovasc. Genet. 2011, 4, 585-594. [CrossRef] [PubMed] 
153. Arad, M.; Penas-Lado, M.; Monserrat, L.; Maron, B.J.; Sherrid, M.; Ho, C.Y.; Barr, S.; Karim, A.; Olson, T.M.; Kamisago, M.; et al. Gene mutations in apical hypertrophic cardiomyopathy. Circulation 2005, 112, 2805-2811. [CrossRef] [PubMed]

154. Kopajtich, R.; Nicholls, T.J.; Rorbach, J.; Metodiev, M.D.; Freisinger, P.; Mandel, H.; Vanlander, A.; Ghezzi, D.; Carrozzo, R.; Taylor, R.W.; et al. Mutations in GTPBP3 cause a mitochondrial translation defect associated with hypertrophic cardiomyopathy, lactic acidosis, and encephalopathy. Am. J. Hum. Genet. 2014, 95, 708-720. [CrossRef] [PubMed]

155. Zhou, Y.M.; Dai, X.Y.; Qiu, X.B.; Yuan, F.; Li, R.G.; Xu, Y.J.; Qu, X.K.; Huang, R.T.; Xue, S.; Yang, Y.Q. HAND1 loss-of-function mutation associated with familial dilated cardiomyopathy. Clin. Chem. Lab. Med. 2016, 54, 1161-1167. [CrossRef] [PubMed]

156. Liu, H.; Xu, Y.J.; Li, R.G.; Wang, Z.S.; Zhang, M.; Qu, X.K.; Qiao, Q.; Li, X.M.; Di, R.M.; Qiu, X.B.; et al. HAND2 loss-of-function mutation causes familial dilated cardiomyopathy. Eur. J. Med. Genet. 2018. [CrossRef] [PubMed]

157. Milano, A.; Vermeer, A.M.; Lodder, E.M.; Barc, J.; Verkerk, A.O.; Postma, A.V.; van der Bilt, I.A.; Baars, M.J.; van Haelst, P.L.; Caliskan, K.; et al. HCN4 mutations in multiple families with bradycardia and left ventricular noncompaction cardiomyopathy. J. Am. Coll. Cardiol. 2014, 64, 745-756. [CrossRef] [PubMed]

158. Hiippala, A.; Vasilescu, C.; Tallila, J.; Alastalo, T.P.; Paetau, A.; Tyni, T.; Suomalainen, A.; Euro, L.; Ojala, T. The rare Costello variant $H R A S$ c.173C $>$ T (p.T58I) with severe neonatal hypertrophic cardiomyopathy. Am. J. Med. Genet. Part A 2016, 170, 1433-1438. [CrossRef] [PubMed]

159. Knoll, R.; Postel, R.; Wang, J.; Kratzner, R.; Hennecke, G.; Vacaru, A.M.; Vakeel, P.; Schubert, C.; Murthy, K.; Rana, B.K.; et al. Laminin-alpha4 and integrin-linked kinase mutations cause human cardiomyopathy via simultaneous defects in cardiomyocytes and endothelial cells. Circulation 2007, 116, 515-525. [CrossRef] [PubMed]

160. Meder, B.; Haas, J.; Keller, A.; Heid, C.; Just, S.; Borries, A.; Boisguerin, V.; Scharfenberger-Schmeer, M.; Stahler, P.; Beier, M.; et al. Targeted next-generation sequencing for the molecular genetic diagnostics of cardiomyopathies. Circ. Cardiovasc. Genet. 2011, 4, 110-122. [CrossRef] [PubMed]

161. Xu, Y.J.; Wang, Z.S.; Yang, C.X.; Di, R.M.; Qiao, Q.; Li, X.M.; Gu, J.N.; Guo, X.J.; Yang, Y.Q. Identification and functional characterization of an ISL1 mutation predisposing to dilated cardiomyopathy. J. Cardiovasc. Transl. Res. 2019, 12, 257-267. [CrossRef] [PubMed]

162. Esposito, T.; Sampaolo, S.; Limongelli, G.; Varone, A.; Formicola, D.; Diodato, D.; Farina, O.; Napolitano, F.; Pacileo, G.; Gianfrancesco, F.; et al. Digenic mutational inheritance of the integrin alpha 7 and the myosin heavy chain 7B genes causes congenital myopathy with left ventricular non-compact cardiomyopathy. Orphanet J. Rare Dis. 2013, 8, 91. [CrossRef] [PubMed]

163. Handley, M.T.; Reddy, K.; Wills, J.; Rosser, E.; Kamath, A.; Halachev, M.; Falkous, G.; Williams, D.; Cox, P.; Meynert, A.; et al. ITPase deficiency causes a Martsolf-like syndrome with a lethal infantile dilated cardiomyopathy. PLoS Genet. 2019, 15, e1007605. [CrossRef] [PubMed]

164. Matsushita, Y.; Furukawa, T.; Kasanuki, H.; Nishibatake, M.; Kurihara, Y.; Ikeda, A.; Kamatani, N.; Takeshima, H.; Matsuoka, R. Mutation of junctophilin type 2 associated with hypertrophic cardiomyopathy. J. Hum. Genet. 2007, 52, 543-548. [CrossRef] [PubMed]

165. Sabater-Molina, M.; Navarro, M.; Garcia-Molina Saez, E.; Garrido, I.; Pascual-Figal, D.; Gonzalez Carrillo, J.; Gimeno Blanes, J.R. Mutation in JPH2 cause dilated cardiomyopathy. Clin. Genet. 2016, 90, 468-469. [CrossRef] [PubMed]

166. Xiong, Q.; Cao, Q.; Zhou, Q.; Xie, J.; Shen, Y.; Wan, R.; Yu, J.; Yan, S.; Marian, A.J.; Hong, K. Arrhythmogenic cardiomyopathy in a patient with a rare loss-of-function KCNQ1 mutation. J. Am. Heart Assoc. 2015, 4, e001526. [CrossRef] [PubMed]

167. Hedberg-Oldfors, C.; Abramsson, A.; Osborn, D.P.S.; Danielsson, O.; Fazlinezhad, A.; Nilipour, Y.; Hubbert, L.; Nennesmo, I.; Visuttijai, K.; Bharj, J.; et al. Cardiomyopathy with lethal arrhythmias associated with inactivation of KLHL24. Hum. Mol. Genet. 2019, 28, 1919-1929. [CrossRef] [PubMed]

168. Arad, M.; Maron, B.J.; Gorham, J.M.; Johnson, W.H., Jr.; Saul, J.P.; Perez-Atayde, A.R.; Spirito, P.; Wright, G.B.; Kanter, R.J.; Seidman, C.E.; et al. Glycogen storage diseases presenting as hypertrophic cardiomyopathy. N. Engl. J. Med. 2005, 352, 362-372. [CrossRef] [PubMed] 
169. Fratev, F.; Mihaylova, E.; Pajeva, I. Combination of genetic screening and molecular dynamics as a useful tool for identification of disease-related mutations: ZASP PDZ domain G54S mutation case. J. Chem. Inf. Model. 2014, 54, 1524-1536. [CrossRef]

170. Vatta, M.; Mohapatra, B.; Jimenez, S.; Sanchez, X.; Faulkner, G.; Perles, Z.; Sinagra, G.; Lin, J.H.; Vu, T.M.; Zhou, Q.; et al. Mutations in Cypher/ZASP in patients with dilated cardiomyopathy and left ventricular non-compaction. J. Am. Coll. Cardiol. 2003, 42, 2014-2027. [CrossRef]

171. Arimura, T.; Hayashi, T.; Terada, H.; Lee, S.Y.; Zhou, Q.; Takahashi, M.; Ueda, K.; Nouchi, T.; Hohda, S.; Shibutani, M.; et al. A Cypher/ZASP mutation associated with dilated cardiomyopathy alters the binding affinity to protein kinase C. J. Biol. Chem. 2004, 279, 6746-6752. [CrossRef] [PubMed]

172. Shan, S.; He, X.; He, L.; Wang, M.; Liu, C. Coexistence of congenital left ventricular aneurysm and prominent left ventricular trabeculation in a patient with LDB3 mutation: A case report. J. Med. Case Rep. 2017, 11, 229. [CrossRef] [PubMed]

173. Lopez-Ayala, J.M.; Ortiz-Genga, M.; Gomez-Milanes, I.; Lopez-Cuenca, D.; Ruiz-Espejo, F.; Sanchez-Munoz, J.J.; Oliva-Sandoval, M.J.; Monserrat, L.; Gimeno, J.R. A mutation in the Z-line Cypher/ZASP protein is associated with arrhythmogenic right ventricular cardiomyopathy. Clin. Genet. 2015, 88, 172-176. [CrossRef] [PubMed]

174. Boone, P.M.; Yuan, B.; Gu, S.; Ma, Z.; Gambin, T.; Gonzaga-Jauregui, C.; Jain, M.; Murdock, T.J.; White, J.J.; Jhangiani, S.N.; et al. Hutterite-type cataract maps to chromosome 6p21.32-p21.31, cosegregates with a homozygous mutation in LEMD2, and is associated with sudden cardiac death. Mol. Genet. Genom. Med. 2016, 4, 77-94. [CrossRef] [PubMed]

175. Liu, Z.; Shan, H.; Huang, J.; Li, N.; Hou, C.; Pu, J. A novel lamin A/C gene missense mutation (445 V > E) in immunoglobulin-like fold associated with left ventricular non-compaction. Europace 2016, 18, 617-622. [CrossRef] [PubMed]

176. Qu, X.K.; Yuan, F.; Li, R.G.; Xu, L.; Jing, W.F.; Liu, H.; Xu, Y.J.; Zhang, M.; Liu, X.; Fang, W.Y.; et al. Prevalence and spectrum of LRRC10 mutations associated with idiopathic dilated cardiomyopathy. Mol. Med. Rep. 2015, 12, 3718-3724. [CrossRef]

177. Luxan, G.; Casanova, J.C.; Martinez-Poveda, B.; Prados, B.; D’Amato, G.; MacGrogan, D.; Gonzalez-Rajal, A.; Dobarro, D.; Torroja, C.; Martinez, F.; et al. Mutations in the NOTCH pathway regulator MIB1 cause left ventricular noncompaction cardiomyopathy. Nat. Med. 2013, 19, 193-201. [CrossRef]

178. Piccolo, P.; Attanasio, S.; Secco, I.; Sangermano, R.; Strisciuglio, C.; Limongelli, G.; Miele, E.; Mutarelli, M.; Banfi, S.; Nigro, V.; et al. MIB2 variants altering NOTCH signalling result in left ventricle hypertrabeculation/non-compaction and are associated with Menetrier-like gastropathy. Hum. Mol. Genet. 2017, 26, 33-43.

179. Galmiche, L.; Serre, V.; Beinat, M.; Assouline, Z.; Lebre, A.S.; Chretien, D.; Nietschke, P.; Benes, V.; Boddaert, N.; Sidi, D.; et al. Exome sequencing identifies MRPL3 mutation in mitochondrial cardiomyopathy. Hum. Mutat. 2011, 32, 1225-1231. [CrossRef]

180. Carroll, C.J.; Isohanni, P.; Poyhonen, R.; Euro, L.; Richter, U.; Brilhante, V.; Gotz, A.; Lahtinen, T.; Paetau, A.; Pihko, H.; et al. Whole-exome sequencing identifies a mutation in the mitochondrial ribosome protein MRPL44 to underlie mitochondrial infantile cardiomyopathy. J. Med. Genet. 2013, 50, 151-159. [CrossRef]

181. Distelmaier, F.; Haack, T.B.; Catarino, C.B.; Gallenmuller, C.; Rodenburg, R.J.; Strom, T.M.; Baertling, F.; Meitinger, T.; Mayatepek, E.; Prokisch, H.; et al. MRPL44 mutations cause a slowly progressive multisystem disease with childhood-onset hypertrophic cardiomyopathy. NeuroGenet. 2015, 16, 319-323. [CrossRef] [PubMed]

182. Watkins, H.; Conner, D.; Thierfelder, L.; Jarcho, J.A.; MacRae, C.; McKenna, W.J.; Maron, B.J.; Seidman, J.G.; Seidman, C.E. Mutations in the cardiac myosin binding protein-C gene on chromosome 11 cause familial hypertrophic cardiomyopathy. Nat. Genet. 1995, 11, 434-437. [CrossRef] [PubMed]

183. Carrier, L.; Bonne, G.; Bahrend, E.; Yu, B.; Richard, P.; Niel, F.; Hainque, B.; Cruaud, C.; Gary, F.; Labeit, S.; et al. Organization and sequence of human cardiac myosin binding protein $\mathrm{C}$ gene (MYBPC3) and identification of mutations predicted to produce truncated proteins in familial hypertrophic cardiomyopathy. Circ. Res. 1997, 80, 427-434. [CrossRef] [PubMed]

184. Ehlermann, P.; Weichenhan, D.; Zehelein, J.; Steen, H.; Pribe, R.; Zeller, R.; Lehrke, S.; Zugck, C.; Ivandic, B.T.; Katus, H.A. Adverse events in families with hypertrophic or dilated cardiomyopathy and mutations in the MYBPC3 gene. BMC Med. Genet. 2008, 9, 95. [CrossRef] [PubMed] 
185. Dellefave, L.M.; Pytel, P.; Mewborn, S.; Mora, B.; Guris, D.L.; Fedson, S.; Waggoner, D.; Moskowitz, I.; McNally, E.M. Sarcomere mutations in cardiomyopathy with left ventricular hypertrabeculation. Circ. Cardiovasc. Genet. 2009, 2, 442-449. [CrossRef] [PubMed]

186. Wu, W.; Lu, C.X.; Wang, Y.N.; Liu, F.; Chen, W.; Liu, Y.T.; Han, Y.C.; Cao, J.; Zhang, S.Y.; Zhang, X. Novel phenotype-genotype correlations of restrictive cardiomyopathy with Myosin-Binding Protein C (MYBPC3) gene mutations tested by next-generation sequencing. J. Am. Heart Assoc. 2015, 4, e001879. [CrossRef]

187. Barefield, D.Y.; Puckelwartz, M.J.; Kim, E.Y.; Wilsbacher, L.D.; Vo, A.H.; Waters, E.A.; Earley, J.U.; Hadhazy, M.; Dellefave-Castillo, L.; Pesce, L.L.; et al. Experimental modeling supports a role for MyBP-HL as a novel myofilament component in arrhythmia and dilated cardiomyopathy. Circulation 2017, 136, 1477-1491. [CrossRef] [PubMed]

188. Carniel, E.; Taylor, M.R.; Sinagra, G.; Di Lenarda, A.; Ku, L.; Fain, P.R.; Boucek, M.M.; Cavanaugh, J.; Miocic, S.; Slavov, D.; et al. $\alpha$-myosin heavy chain: A sarcomeric gene associated with dilated and hypertrophic phenotypes of cardiomyopathy. Circulation 2005, 112, 54-59. [CrossRef]

189. Greenway, S.C.; Wilson, G.J.; Wilson, J.; George, K.; Kantor, P.F. Sudden death in an infant with angina, restrictive cardiomyopathy, and coronary artery bridging: An unusual phenotype for a beta-myosin heavy chain (MYH7) sarcomeric protein mutation. Circ. Heart Fail. 2012, 5, e92-e93. [CrossRef]

190. Flavigny, J.; Richard, P.; Isnard, R.; Carrier, L.; Charron, P.; Bonne, G.; Forissier, J.F.; Desnos, M.; Dubourg, O.; Komajda, M.; et al. Identification of two novel mutations in the ventricular regulatory myosin light chain gene (MYL2) associated with familial and classical forms of hypertrophic cardiomyopathy. J. Mol. Med. 1998, 76, 208-214. [CrossRef]

191. Caleshu, C.; Sakhuja, R.; Nussbaum, R.L.; Schiller, N.B.; Ursell, P.C.; Eng, C.; De Marco, T.; McGlothlin, D.; Burchard, E.G.; Rame, J.E. Furthering the link between the sarcomere and primary cardiomyopathies: Restrictive cardiomyopathy associated with multiple mutations in genes previously associated with hypertrophic or dilated cardiomyopathy. Am. J. Med. Genet. Part A 2011, 155A, 2229-2235. [CrossRef] [PubMed]

192. Choi, J.O.; Yu, C.W.; Chun Nah, J.; Rang Park, J.; Lee, B.S.; Jeong Choi, Y.; Cho, B.R.; Lee, S.C.; Woo Park, S.; Kimura, A.; et al. Long-term outcome of 4 Korean families with hypertrophic cardiomyopathy caused by 4 different mutations. Clin. Cardiol. 2010, 33, 430-438. [CrossRef] [PubMed]

193. Tobita, T.; Nomura, S.; Morita, H.; Ko, T.; Fujita, T.; Toko, H.; Uto, K.; Hagiwara, N.; Aburatani, H.; Komuro, I. Identification of MYLK3 mutations in familial dilated cardiomyopathy. Sci. Rep. 2017, 7, 17495. [CrossRef] [PubMed]

194. Arola, A.M.; Sanchez, X.; Murphy, R.T.; Hasle, E.; Li, H.; Elliott, P.M.; McKenna, W.J.; Towbin, J.A.; Bowles, N.E. Mutations in PDLIM3 and MYOZ1 encoding myocyte $\mathrm{Z}$ line proteins are infrequently found in idiopathic dilated cardiomyopathy. Mol. Genet. Metab. 2007, 90, 435-440. [CrossRef] [PubMed]

195. Osio, A.; Tan, L.; Chen, S.N.; Lombardi, R.; Nagueh, S.F.; Shete, S.; Roberts, R.; Willerson, J.T.; Marian, A.J. Myozenin 2 is a novel gene for human hypertrophic cardiomyopathy. Circ. Res. 2007, 100, 766-768. [CrossRef] [PubMed]

196. Purevjav, E.; Arimura, T.; Augustin, S.; Huby, A.C.; Takagi, K.; Nunoda, S.; Kearney, D.L.; Taylor, M.D.; Terasaki, F.; Bos, J.M.; et al. Molecular basis for clinical heterogeneity in inherited cardiomyopathies due to myopalladin mutations. Hum. Mol. Genet. 2012, 21, 2039-2053. [CrossRef] [PubMed]

197. Meyer, T.; Ruppert, V.; Ackermann, S.; Richter, A.; Perrot, A.; Sperling, S.R.; Posch, M.G.; Maisch, B.; Pankuweit, S. Novel mutations in the sarcomeric protein myopalladin in patients with dilated cardiomyopathy. Eur. J. Hum. Genet. 2013, 21, 294-300. [CrossRef] [PubMed]

198. Huby, A.C.; Mendsaikhan, U.; Takagi, K.; Martherus, R.; Wansapura, J.; Gong, N.; Osinska, H.; James, J.F.; Kramer, K.; Saito, K.; et al. Disturbance in Z-disk mechanosensitive proteins induced by a persistent mutant myopalladin causes familial restrictive cardiomyopathy. J. Am. Coll. Cardiol. 2014, 64, 2765-2776. [CrossRef]

199. Roh, J.I.; Cheong, C.; Sung, Y.H.; Lee, J.; Oh, J.; Lee, B.S.; Lee, J.E.; Gho, Y.S.; Kim, D.K.; Park, C.B.; et al. Perturbation of NCOA6 leads to dilated cardiomyopathy. Cell Rep. 2014, 8, 991-998. [CrossRef]

200. Fassone, E.; Taanman, J.W.; Hargreaves, I.P.; Sebire, N.J.; Cleary, M.A.; Burch, M.; Rahman, S. Mutations in the mitochondrial complex I assembly factor NDUFAF1 cause fatal infantile hypertrophic cardiomyopathy. J. Med. Genet. 2011, 48, 691-697. [CrossRef]

201. Benit, P.; Beugnot, R.; Chretien, D.; Giurgea, I.; De Lonlay-Debeney, P.; Issartel, J.P.; Corral-Debrinski, M.; Kerscher, S.; Rustin, P.; Rotig, A.; et al. Mutant NDUFV2 subunit of mitochondrial complex I causes early onset hypertrophic cardiomyopathy and encephalopathy. Hum. Mutat. 2003, 21, 582-586. [CrossRef] [PubMed] 
202. Benit, P.; Slama, A.; Cartault, F.; Giurgea, I.; Chretien, D.; Lebon, S.; Marsac, C.; Munnich, A.; Rotig, A.; Rustin, P. Mutant NDUFS3 subunit of mitochondrial complex I causes Leigh syndrome. J. Med. Genet. 2004, 41, 14-17. [CrossRef] [PubMed]

203. Perrot, A.; Tomasov, P.; Villard, E.; Faludi, R.; Melacini, P.; Lossie, J.; Lohmann, N.; Richard, P.; De Bortoli, M.; Angelini, A.; et al. Mutations in NEBL encoding the cardiac Z-disk protein nebulette are associated with various cardiomyopathies. Arch. Med. Sci. 2016, 12, 263-278. [CrossRef] [PubMed]

204. Arimura, T.; Nakamura, T.; Hiroi, S.; Satoh, M.; Takahashi, M.; Ohbuchi, N.; Ueda, K.; Nouchi, T.; Yamaguchi, N.; Akai, J.; et al. Characterization of the human nebulette gene: A polymorphism in an actin-binding motif is associated with nonfamilial idiopathic dilated cardiomyopathy. Hum. Genet. 2000, 107, 440-451. [CrossRef] [PubMed]

205. Wang, H.; Li, Z.; Wang, J.; Sun, K.; Cui, Q.; Song, L.; Zou, Y.; Wang, X.; Liu, X.; Hui, R.; et al. Mutations in NEXN, a Z-disc gene, are associated with hypertrophic cardiomyopathy. Am. J. Hum. Genet. 2010, 87, 687-693. [CrossRef] [PubMed]

206. Hassel, D.; Dahme, T.; Erdmann, J.; Meder, B.; Huge, A.; Stoll, M.; Just, S.; Hess, A.; Ehlermann, P.; Weichenhan, D.; et al. Nexilin mutations destabilize cardiac Z-disks and lead to dilated cardiomyopathy. Nat. Med. 2009, 15, 1281-1288. [CrossRef] [PubMed]

207. Yuen, T.; Borle, K.; Wenzel, K.; Eileen, P.; French, V.; Brodehl, A.; Lauzon, J.; Sharma, P.; Klaassen, S.; Gerull, B. Novel Variants in Nexilin are Associated with Left Ventricular Noncompaction Cardiomyopathy. Circulation 2014, 130, A17287.

208. Xu, J.H.; Gu, J.Y.; Guo, Y.H.; Zhang, H.; Qiu, X.B.; Li, R.G.; Shi, H.Y.; Liu, H.; Yang, X.X.; Xu, Y.J.; et al. Prevalence and spectrum of NKX2-5 mutations associated with sporadic adult-onset dilated cardiomyopathy. Int. Heart J. 2017, 58, 521-529. [CrossRef]

209. Marston, S.; Montgiraud, C.; Munster, A.B.; Copeland, O.; Choi, O.; Dos Remedios, C.; Messer, A.E.; Ehler, E.; Knoll, R. OBSCN mutations associated with dilated cardiomyopathy and haploinsufficiency. PLoS ONE 2015, 10, e0138568. [CrossRef] [PubMed]

210. Biswas, A.; Raza, A.; Das, S.; Kapoor, M.; Jayarajan, R.; Verma, A.; Shamsudheen, K.V.; Murry, B.; Seth, S.; Bhargava, B.; et al. Loss of function mutation in the P2X7, a ligand-gated ion channel gene associated with hypertrophic cardiomyopathy. Purinergic Signall. 2019, 15, 205-210. [CrossRef]

211. Ramond, F.; Janin, A.; Di Filippo, S.; Chanavat, V.; Chalabreysse, L.; Roux-Buisson, N.; Sanlaville, D.; Touraine, R.; Millat, G. Homozygous PKP2 deletion associated with neonatal left ventricle noncompaction. Clin. Genet. 2017, 91, 126-130. [CrossRef] [PubMed]

212. Gerull, B.; Kirchner, F.; Chong, J.X.; Tagoe, J.; Chandrasekharan, K.; Strohm, O.; Waggoner, D.; Ober, C.; Duff, H.J. Homozygous founder mutation in desmocollin-2 (DSC2) causes arrhythmogenic cardiomyopathy in the Hutterite population. Circ. Cardiovasc. Genet. 2013, 6, 327-336. [CrossRef] [PubMed]

213. Haghighi, K.; Kolokathis, F.; Pater, L.; Lynch, R.A.; Asahi, M.; Gramolini, A.O.; Fan, G.C.; Tsiapras, D.; Hahn, H.S.; Adamopoulos, S.; et al. Human phospholamban null results in lethal dilated cardiomyopathy revealing a critical difference between mouse and human. J. Clin. Investig. 2003, 111, 869-876. [CrossRef] [PubMed]

214. Schmitt, J.P.; Kamisago, M.; Asahi, M.; Li, G.H.; Ahmad, F.; Mende, U.; Kranias, E.G.; MacLennan, D.H.; Seidman, J.G.; Seidman, C.E. Dilated cardiomyopathy and heart failure caused by a mutation in phospholamban. Science 2003, 299, 1410-1413. [CrossRef] [PubMed]

215. Iuso, A.; Wiersma, M.; Schuller, H.J.; Pode-Shakked, B.; Marek-Yagel, D.; Grigat, M.; Schwarzmayr, T.; Berutti, R.; Alhaddad, B.; Kanon, B.; et al. Mutations in PPCS, encoding phosphopantothenoylcysteine synthetase, cause autosomal-recessive dilated cardiomyopathy. Am. J. Hum. Genet. 2018, 102, 1018-1030. [CrossRef]

216. Long, P.A.; Evans, J.M.; Olson, T.M. Diagnostic yield of whole exome sequencing in pediatric dilated cardiomyopathy. J. Cardiovasc. Dev. Dis. 2017, 4, 11. [CrossRef]

217. Arndt, A.K.; Schafer, S.; Drenckhahn, J.D.; Sabeh, M.K.; Plovie, E.R.; Caliebe, A.; Klopocki, E.; Musso, G.; Werdich, A.A.; Kalwa, H.; et al. Fine mapping of the 1p36 deletion syndrome identifies mutation of PRDM16 as a cause of cardiomyopathy. Am. J. Hum. Genet. 2013, 93, 67-77. [CrossRef]

218. Blair, E.; Redwood, C.; Ashrafian, H.; Oliveira, M.; Broxholme, J.; Kerr, B.; Salmon, A.; Ostman-Smith, I.; Watkins, H. Mutations in the $\gamma(2)$ subunit of AMP-activated protein kinase cause familial hypertrophic cardiomyopathy: Evidence for the central role of energy compromise in disease pathogenesis. Hum. Mol. Genet. 2001, 10, 1215-1220. [CrossRef] 
219. Vaughan, C.J.; Hom, Y.; Okin, D.A.; McDermott, D.A.; Lerman, B.B.; Basson, C.T. Molecular genetic analysis of PRKAG2 in sporadic Wolff-Parkinson-White syndrome. J. Cardiovasc. Electrophysiol. 2003, 14, 263-268. [CrossRef]

220. Li, D.; Parks, S.B.; Kushner, J.D.; Nauman, D.; Burgess, D.; Ludwigsen, S.; Partain, J.; Nixon, R.R.; Allen, C.N.; Irwin, R.P.; et al. Mutations of presenilin genes in dilated cardiomyopathy and heart failure. Am. J. Hum. Genet. 2006, 79, 1030-1039. [CrossRef]

221. Gianni, D.; Li, A.; Tesco, G.; McKay, K.M.; Moore, J.; Raygor, K.; Rota, M.; Gwathmey, J.K.; Dec, G.W.; Aretz, T.; et al. Protein aggregates and novel presenilin gene variants in idiopathic dilated cardiomyopathy. Circulation 2010, 121, 1216-1226. [CrossRef] [PubMed]

222. Tartaglia, M.; Mehler, E.L.; Goldberg, R.; Zampino, G.; Brunner, H.G.; Kremer, H.; van der Burgt, I.; Crosby, A.H.; Ion, A.; Jeffery, S.; et al. Mutations in PTPN11, encoding the protein tyrosine phosphatase SHP-2, cause Noonan syndrome. Nat. Genet. 2001, 29, 465-468. [CrossRef] [PubMed]

223. Razzaque, M.A.; Nishizawa, T.; Komoike, Y.; Yagi, H.; Furutani, M.; Amo, R.; Kamisago, M.; Momma, K.; Katayama, H.; Nakagawa, M.; et al. Germline gain-of-function mutations in RAF1 cause Noonan syndrome. Nat. Genet. 2007, 39, 1013-1017. [CrossRef] [PubMed]

224. Pandit, B.; Sarkozy, A.; Pennacchio, L.A.; Carta, C.; Oishi, K.; Martinelli, S.; Pogna, E.A.; Schackwitz, W.; Ustaszewska, A.; Landstrom, A.; et al. Gain-of-function RAF1 mutations cause Noonan and LEOPARD syndromes with hypertrophic cardiomyopathy. Nat. Genet. 2007, 39, 1007-1012. [CrossRef] [PubMed]

225. Dhandapany, P.S.; Razzaque, M.A.; Muthusami, U.; Kunnoth, S.; Edwards, J.J.; Mulero-Navarro, S.; Riess, I.; Pardo, S.; Sheng, J.; Rani, D.S.; et al. RAF1 mutations in childhood-onset dilated cardiomyopathy. Nat. Genet. 2014, 46, 635-639. [CrossRef] [PubMed]

226. Guo, W.; Schafer, S.; Greaser, M.L.; Radke, M.H.; Liss, M.; Govindarajan, T.; Maatz, H.; Schulz, H.; Li, S.; Parrish, A.M.; et al. RBM20, a gene for hereditary cardiomyopathy, regulates titin splicing. Nat. Med. 2012, 18, 766-773. [CrossRef] [PubMed]

227. Sedaghat-Hamedani, F.; Haas, J.; Zhu, F.; Geier, C.; Kayvanpour, E.; Liss, M.; Lai, A.; Frese, K.; Pribe-Wolferts, R.; Amr, A.; et al. Clinical genetics and outcome of left ventricular non-compaction cardiomyopathy. Eur. Heart J. 2017, 38, 3449-3460. [CrossRef]

228. Van den Hoogenhof, M.M.G.; Beqqali, A.; Amin, A.S.; van der Made, I.; Aufiero, S.; Khan, M.A.F.; Schumacher, C.A.; Jansweijer, J.A.; van Spaendonck-Zwarts, K.Y.; Remme, C.A.; et al. RBM20 mutations induce an arrhythmogenic dilated cardiomyopathy related to disturbed calcium handling. Circulation 2018, 138, 1330-1342. [CrossRef]

229. Parikh, V.N.; Caleshu, C.; Reuter, C.; Lazzeroni, L.C.; Ingles, J.; Garcia, J.; McCaleb, K.; Adesiyun, T.; Sedaghat-Hamedani, F.; Kumar, S.; et al. Regional variation in RBM20 causes a highly penetrant arrhythmogenic cardiomyopathy. Circ. Heart Fail. 2019, 12, e005371. [CrossRef] [PubMed]

230. Long, P.A.; Zimmermann, M.T.; Kim, M.; Evans, J.M.; Xu, X.; Olson, T.M. De novo RRAGC mutation activates mTORC1 signaling in syndromic fetal dilated cardiomyopathy. Hum. Genet. 2016, 135, 909-917. [CrossRef]

231. Mann, S.A.; Castro, M.L.; Ohanian, M.; Guo, G.; Zodgekar, P.; Sheu, A.; Stockhammer, K.; Thompson, T.; Playford, D.; Subbiah, R.; et al. R222Q SCN5A mutation is associated with reversible ventricular ectopy and dilated cardiomyopathy. J. Am. Coll. Cardiol. 2012, 60, 1566-1573. [CrossRef] [PubMed]

232. Erkapic, D.; Neumann, T.; Schmitt, J.; Sperzel, J.; Berkowitsch, A.; Kuniss, M.; Hamm, C.W.; Pitschner, H.F. Electrical storm in a patient with arrhythmogenic right ventricular cardiomyopathy and SCN5A mutation. Europace 2008, 10, 884-887. [CrossRef] [PubMed]

233. Jaksch, M.; Ogilvie, I.; Yao, J.; Kortenhaus, G.; Bresser, H.G.; Gerbitz, K.D.; Shoubridge, E.A. Mutations in $\mathrm{SCO} 2$ are associated with a distinct form of hypertrophic cardiomyopathy and cytochrome c oxidase deficiency. Hum. Mol. Genet. 2000, 9, 795-801. [CrossRef] [PubMed]

234. Levitas, A.; Muhammad, E.; Harel, G.; Saada, A.; Caspi, V.C.; Manor, E.; Beck, J.C.; Sheffield, V.; Parvari, R. Familial neonatal isolated cardiomyopathy caused by a mutation in the flavoprotein subunit of succinate dehydrogenase. Eur. J. Hum. Genet. 2010, 18, 1160-1165. [CrossRef] [PubMed]

235. Van Spaendonck-Zwarts, K.Y.; van Rijsingen, I.A.; van den Berg, M.P.; Lekanne Deprez, R.H.; Post, J.G.; van Mil, A.M.; Asselbergs, F.W.; Christiaans, I.; van Langen, I.M.; Wilde, A.A.; et al. Genetic analysis in 418 index patients with idiopathic dilated cardiomyopathy: Overview of 10 years' experience. Eur. J. Heart Fail. 2013, 15, 628-636. [CrossRef] [PubMed] 
236. Tsubata, S.; Bowles, K.R.; Vatta, M.; Zintz, C.; Titus, J.; Muhonen, L.; Bowles, N.E.; Towbin, J.A. Mutations in the human $\delta$-sarcoglycan gene in familial and sporadic dilated cardiomyopathy. J. Clin. Investig. 2000, 106, 655-662. [CrossRef] [PubMed]

237. Hoban, R.; Roberts, A.E.; Demmer, L.; Jethva, R.; Shephard, B. Noonan syndrome due to a SHOC2 mutation presenting with fetal distress and fatal hypertrophic cardiomyopathy in a premature infant. Am. J. Med. Genet. Part A 2012, 158A, 1411-1413. [CrossRef]

238. Sandra, M.; Maria Pia, L.; Stefano, C.; Pietro, P.; Crociani, P.; Aldo, R.; Giuseppe, D.S.; Massimo, C. Emery-dreifuss muscular dystrophy type 4: A new SYNE1 mutation associated with hypertrophic cardiomyopathy masked by a perinatal distress-related spastic diplegia. Clin. Case Rep. 2019, 7, 1078-1082. [CrossRef]

239. Puckelwartz, M.J.; Kessler, E.J.; Kim, G.; Dewitt, M.M.; Zhang, Y.; Earley, J.U.; Depreux, F.F.; Holaska, J.; Mewborn, S.K.; Pytel, P.; et al. Nesprin-1 mutations in human and murine cardiomyopathy. J. Mol. Cell. Cardiol. 2010, 48, 600-608. [CrossRef]

240. Bione, S.; D'Adamo, P.; Maestrini, E.; Gedeon, A.K.; Bolhuis, P.A.; Toniolo, D. A novel X-linked gene, G4.5. is responsible for Barth syndrome. Nat. Genet. 1996, 12, 385-389. [CrossRef]

241. Xing, Y.; Ichida, F.; Matsuoka, T.; Isobe, T.; Ikemoto, Y.; Higaki, T.; Tsuji, T.; Haneda, N.; Kuwabara, A.; Chen, R.; et al. Genetic analysis in patients with left ventricular noncompaction and evidence for genetic heterogeneity. Mol. Genet. Metab. 2006, 88, 71-77. [CrossRef] [PubMed]

242. Wang, C.; Hata, Y.; Hirono, K.; Takasaki, A.; Ozawa, S.W.; Nakaoka, H.; Saito, K.; Miyao, N.; Okabe, M.; Ibuki, K.; et al. A wide and specific spectrum of genetic variants and genotype-phenotype correlations revealed by next-generation sequencing in patients with left ventricular noncompaction. J. Am. Heart Assoc. 2017, 6, e006210. [CrossRef] [PubMed]

243. Kirk, E.P.; Sunde, M.; Costa, M.W.; Rankin, S.A.; Wolstein, O.; Castro, M.L.; Butler, T.L.; Hyun, C.; Guo, G.; Otway, R.; et al. Mutations in cardiac T-box factor gene TBX20 are associated with diverse cardiac pathologies, including defects of septation and valvulogenesis and cardiomyopathy. Am. J. Hum. Genet. 2007, 81, $280-291$. [CrossRef] [PubMed]

244. Zhao, C.M.; Bing, S.; Song, H.M.; Wang, J.; Xu, W.J.; Jiang, J.F.; Qiu, X.B.; Yuan, F.; Xu, J.H.; Yang, Y.Q. TBX20 loss-of-function mutation associated with familial dilated cardiomyopathy. Clin. Chem. Lab. Med. 2016, 54, 325-332. [CrossRef] [PubMed]

245. Hayashi, T.; Arimura, T.; Itoh-Satoh, M.; Ueda, K.; Hohda, S.; Inagaki, N.; Takahashi, M.; Hori, H.; Yasunami, M.; Nishi, H.; et al. Tcap gene mutations in hypertrophic cardiomyopathy and dilated cardiomyopathy. J. Am. Coll. Cardiol. 2004, 44, 2192-2201. [CrossRef] [PubMed]

246. Beffagna, G.; Occhi, G.; Nava, A.; Vitiello, L.; Ditadi, A.; Basso, C.; Bauce, B.; Carraro, G.; Thiene, G.; Towbin, J.A.; et al. Regulatory mutations in transforming growth factor-beta3 gene cause arrhythmogenic right ventricular cardiomyopathy type 1. Cardiovasc. Res. 2005, 65, 366-373. [CrossRef] [PubMed]

247. De Bortoli, M.; Postma, A.V.; Poloni, G.; Calore, M.; Minervini, G.; Mazzotti, E.; Rigato, I.; Ebert, M.; Lorenzon, A.; Vazza, G.; et al. Whole-exome sequencing identifies pathogenic variants in TJP1 gene associated with arrhythmogenic cardiomyopathy. Circ. Genom. Precis. Med. 2018, 11, e002123. [CrossRef]

248. Yu, H.C.; Coughlin, C.R.; Geiger, E.A.; Salvador, B.J.; Elias, E.R.; Cavanaugh, J.L.; Chatfield, K.C.; Miyamoto, S.D.; Shaikh, T.H. Discovery of a potentially deleterious variant in TMEM87B in a patient with a hemizygous $2 q 13$ microdeletion suggests a recessive condition characterized by congenital heart disease and restrictive cardiomyopathy. Cold Spring Harb. Mol. Case Stud. 2016, 2, a000844. [CrossRef]

249. Mogensen, J.; Murphy, R.T.; Shaw, T.; Bahl, A.; Redwood, C.; Watkins, H.; Burke, M.; Elliott, P.M.; McKenna, W.J. Severe disease expression of cardiac troponin $\mathrm{C}$ and $\mathrm{T}$ mutations in patients with idiopathic dilated cardiomyopathy. J. Am. Coll. Cardiol. 2004, 44, 2033-2040. [CrossRef]

250. Ploski, R.; Rydzanicz, M.; Ksiazczyk, T.M.; Franaszczyk, M.; Pollak, A.; Kosinska, J.; Michalak, E.; Stawinski, P.; Ziolkowska, L.; Bilinska, Z.T.; et al. Evidence for troponin C (TNNC1) as a gene for autosomal recessive restrictive cardiomyopathy with fatal outcome in infancy. Am. J. Med. Genet. Part A 2016, 170, 3241-3248. [CrossRef]

251. Murphy, R.T.; Mogensen, J.; Shaw, A.; Kubo, T.; Hughes, S.; McKenna, W.J. Novel mutation in cardiac troponin I in recessive idiopathic dilated cardiomyopathy. Lancet 2004, 363, 371-372. [CrossRef] 
252. Fujino, M.; Tsuda, E.; Hirono, K.; Nakata, M.; Ichida, F.; Hata, Y.; Nishida, N.; Kurosaki, K. The TNNI3 Arg192His mutation in a 13-year-old girl with left ventricular noncompaction. J. Cardiol. Cases 2018, 18, 33-36. [CrossRef] [PubMed]

253. Fan, L.L.; Huang, H.; Jin, J.Y.; Li, J.J.; Chen, Y.Q.; Zhao, S.P.; Xiang, R. Whole exome sequencing identifies a novel mutation (c.333 $+2 \mathrm{~T}>\mathrm{C}$ ) of TNNI3K in a Chinese family with dilated cardiomyopathy and cardiac conduction disease. Gene 2018, 648, 63-67. [CrossRef] [PubMed]

254. Hanson, E.L.; Jakobs, P.M.; Keegan, H.; Coates, K.; Bousman, S.; Dienel, N.H.; Litt, M.; Hershberger, R.E. Cardiac troponin T lysine 210 deletion in a family with dilated cardiomyopathy. J. Card. Fail. 2002, 8, 28-32. [CrossRef] [PubMed]

255. Luedde, M.; Ehlermann, P.; Weichenhan, D.; Will, R.; Zeller, R.; Rupp, S.; Muller, A.; Steen, H.; Ivandic, B.T.; Ulmer, H.E.; et al. Severe familial left ventricular non-compaction cardiomyopathy due to a novel troponin $\mathrm{T}$ (TNNT2) mutation. Cardiovasc. Res. 2010, 86, 452-460. [CrossRef] [PubMed]

256. Poloni, G.; Calore, M.; Rigato, I.; Marras, E.; Minervini, G.; Mazzotti, E.; Lorenzon, A.; Li Mura, I.E.A.; Telatin, A.; Zara, I.; et al. A targeted next-generation gene panel reveals a novel heterozygous nonsense variant in the TP63 gene in patients with arrhythmogenic cardiomyopathy. Heart Rhythm 2019, 16, 773-780. [CrossRef]

257. Karibe, A.; Tobacman, L.S.; Strand, J.; Butters, C.; Back, N.; Bachinski, L.L.; Arai, A.E.; Ortiz, A.; Roberts, R.; Homsher, E.; et al. Hypertrophic cardiomyopathy caused by a novel $\alpha$-tropomyosin mutation (V95A) is associated with mild cardiac phenotype, abnormal calcium binding to troponin, abnormal myosin cycling, and poor prognosis. Circulation 2001, 103, 65-71. [CrossRef]

258. Lakdawala, N.K.; Dellefave, L.; Redwood, C.S.; Sparks, E.; Cirino, A.L.; Depalma, S.; Colan, S.D.; Funke, B.; Zimmerman, R.S.; Robinson, P.; et al. Familial dilated cardiomyopathy caused by an $\alpha$-tropomyosin mutation: The distinctive natural history of sarcomeric dilated cardiomyopathy. J. Am. Coll. Cardiol. 2010, 55, 320-329. [CrossRef]

259. Chang, B.; Nishizawa, T.; Furutani, M.; Fujiki, A.; Tani, M.; Kawaguchi, M.; Ibuki, K.; Hirono, K.; Taneichi, H.; Uese, K.; et al. Identification of a novel TPM1 mutation in a family with left ventricular noncompaction and sudden death. Mol. Genet. Metab. 2011, 102, 200-206. [CrossRef]

260. Chen, S.N.; Czernuszewicz, G.; Tan, Y.; Lombardi, R.; Jin, J.; Willerson, J.T.; Marian, A.J. Human molecular genetic and functional studies identify TRIM63, encoding muscle RING finger protein 1, as a novel gene for human hypertrophic cardiomyopathy. Circ. Res. 2012, 111, 907-919. [CrossRef]

261. Saito, Y.; Nakamura, K.; Nishi, N.; Igawa, O.; Yoshida, M.; Miyoshi, T.; Watanabe, A.; Morita, H.; Ito, H. TRPM4 mutation in patients with ventricular noncompaction and cardiac conduction disease. Circ. Genom. Precis. Med. 2018, 11, e002103. [CrossRef] [PubMed]

262. Perli, E.; Pisano, A.; Glasgow, R.I.C.; Carbo, M.; Hardy, S.A.; Falkous, G.; He, L.; Cerbelli, B.; Pignataro, M.G.; Zacara, E.; et al. Novel compound mutations in the mitochondrial translation elongation factor (TSFM) gene cause severe cardiomyopathy with myocardial fibro-adipose replacement. Sci. Rep. 2019, 9, 5108. [CrossRef] [PubMed]

263. Satoh, M.; Takahashi, M.; Sakamoto, T.; Hiroe, M.; Marumo, F.; Kimura, A. Structural analysis of the titin gene in hypertrophic cardiomyopathy: Identification of a novel disease gene. Biochem. Biophys. Res. Commun. 1999, 262, 411-417. [CrossRef] [PubMed]

264. Itoh-Satoh, M.; Hayashi, T.; Nishi, H.; Koga, Y.; Arimura, T.; Koyanagi, T.; Takahashi, M.; Hohda, S.; Ueda, K.; Nouchi, T.; et al. Titin mutations as the molecular basis for dilated cardiomyopathy. Biochem. Biophys. Res. Commun. 2002, 291, 385-393. [CrossRef] [PubMed]

265. Li, S.; Zhang, C.; Liu, N.; Bai, H.; Hou, C.; Song, L.; Pu, J. Titin-truncating variants are associated with heart failure events in patients with left ventricular noncompaction cardiomyopathy. Clin. Cardiol. 2019, 42, 530-535. [CrossRef] [PubMed]

266. Saraiva, M.J.; Almeida Mdo, R.; Sherman, W.; Gawinowicz, M.; Costa, P.; Costa, P.P.; Goodman, D.S. A new transthyretin mutation associated with amyloid cardiomyopathy. Am. J. Hum. Genet. 1992, 50, 1027-1030.

267. Holmgren, G.; Hellman, U.; Anan, I.; Lundgren, H.E.; Jonasson, J.; Stafberg, C.; Fahoum, S.; Suhr, O.B. Cardiomyopathy in Swedish patients with the Gly53Glu and His88Arg transthyretin variants. Amyloid 2005, 12, 184-188. [CrossRef] 
268. Sibbing, D.; Pfeufer, A.; Perisic, T.; Mannes, A.M.; Fritz-Wolf, K.; Unwin, S.; Sinner, M.F.; Gieger, C.; Gloeckner, C.J.; Wichmann, H.E.; et al. Mutations in the mitochondrial thioredoxin reductase gene TXNRD2 cause dilated cardiomyopathy. Eur. Heart J. 2011, 32, 1121-1133. [CrossRef]

269. Vasile, V.C.; Will, M.L.; Ommen, S.R.; Edwards, W.D.; Olson, T.M.; Ackerman, M.J. Identification of a metavinculin missense mutation, R975W, associated with both hypertrophic and dilated cardiomyopathy. Mol. Genet. Metab. 2006, 87, 169-174. [CrossRef]

270. Vasile, V.C.; Ommen, S.R.; Edwards, W.D.; Ackerman, M.J. A missense mutation in a ubiquitously expressed protein, vinculin, confers susceptibility to hypertrophic cardiomyopathy. Biochem. Biophys. Res. Commun. 2006, 345, 998-1003. [CrossRef]

271. Olson, T.M.; Illenberger, S.; Kishimoto, N.Y.; Huttelmaier, S.; Keating, M.T.; Jockusch, B.M. Metavinculin mutations alter actin interaction in dilated cardiomyopathy. Circulation 2002, 105, 431-437. [CrossRef] [PubMed]

272. Buyandelger, B.; Mansfield, C.; Kostin, S.; Choi, O.; Roberts, A.M.; Ware, J.S.; Mazzarotto, F.; Pesce, F.; Buchan, R.; Isaacson, R.L.; et al. ZBTB17 (MIZ1) is important for the cardiac stress response and a novel candidate gene for cardiomyopathy and heart failure. Circ. Cardiovasc. Genet. 2015, 8, 643-652. [CrossRef] [PubMed]

273. Sun, Y.M.; Wang, J.; Xu, Y.J.; Wang, X.H.; Yuan, F.; Liu, H.; Li, R.G.; Zhang, M.; Li, Y.J.; Shi, H.Y.; et al. ZBTB17 loss-of-function mutation contributes to familial dilated cardiomyopathy. Heart Vessels 2018, 33, 722-732. [CrossRef] [PubMed]

274. Gurdon, J.B.; Elsdale, T.R.; Fischberg, M. Sexually mature individuals of Xenopus laevis from the transplantation of single somatic nuclei. Nature 1958, 182, 64-65. [CrossRef] [PubMed]

275. Elsdale, T.R.; Gurdon, J.B.; Fischberg, M. A description of the technique for nuclear transplantation in Xenopus laevis. J. Embryol. Exp. Morphol. 1960, 8, 437-444. [PubMed]

276. Holmes, D. Stem cell scientists share 2012 Nobel Prize for medicine. Lancet 2012, 380, 1295. [CrossRef]

277. Wilmut, I.; Schnieke, A.E.; McWhir, J.; Kind, A.J.; Campbell, K.H. Viable offspring derived from fetal and adult mammalian cells. Nature 1997, 385, 810-813. [CrossRef] [PubMed]

278. Takahashi, K.; Yamanaka, S. Induction of pluripotent stem cells from mouse embryonic and adult fibroblast cultures by defined factors. Cell 2006, 126, 663-676. [CrossRef]

279. Okita, K.; Ichisaka, T.; Yamanaka, S. Generation of germline-competent induced pluripotent stem cells. Nature 2007, 448, 313-317. [CrossRef] [PubMed]

280. Nakagawa, M.; Koyanagi, M.; Tanabe, K.; Takahashi, K.; Ichisaka, T.; Aoi, T.; Okita, K.; Mochiduki, Y.; Takizawa, N.; Yamanaka, S. Generation of induced pluripotent stem cells without Myc from mouse and human fibroblasts. Nat. Biotechnol. 2008, 26, 101-106. [CrossRef] [PubMed]

281. Takahashi, K.; Tanabe, K.; Ohnuki, M.; Narita, M.; Ichisaka, T.; Tomoda, K.; Yamanaka, S. Induction of pluripotent stem cells from adult human fibroblasts by defined factors. Cell 2007, 131, 861-872. [CrossRef] [PubMed]

282. Blelloch, R.; Venere, M.; Yen, J.; Ramalho-Santos, M. Generation of induced pluripotent stem cells in the absence of drug selection. Cell Stem Cell 2007, 1, 245-247. [CrossRef] [PubMed]

283. Yu, J.; Vodyanik, M.A.; Smuga-Otto, K.; Antosiewicz-Bourget, J.; Frane, J.L.; Tian, S.; Nie, J.; Jonsdottir, G.A.; Ruotti, V.; Stewart, R.; et al. Induced pluripotent stem cell lines derived from human somatic cells. Science 2007, 318, 1917-1920. [CrossRef] [PubMed]

284. Brambrink, T.; Foreman, R.; Welstead, G.G.; Lengner, C.J.; Wernig, M.; Suh, H.; Jaenisch, R. Sequential expression of pluripotency markers during direct reprogramming of mouse somatic cells. Cell Stem Cell 2008, 2, 151-159. [CrossRef] [PubMed]

285. Soldner, F.; Hockemeyer, D.; Beard, C.; Gao, Q.; Bell, G.W.; Cook, E.G.; Hargus, G.; Blak, A.; Cooper, O.; Mitalipova, M.; et al. Parkinson's disease patient-derived induced pluripotent stem cells free of viral reprogramming factors. Cell 2009, 136, 964-977. [CrossRef] [PubMed]

286. Hacein-Bey-Abina, S.; von Kalle, C.; Schmidt, M.; Le Deist, F.; Wulffraat, N.; McIntyre, E.; Radford, I.; Villeval, J.L.; Fraser, C.C.; Cavazzana-Calvo, M.; et al. A serious adverse event after successful gene therapy for X-linked severe combined immunodeficiency. N. Engl. J. Med. 2003, 348, 255-256. [CrossRef] [PubMed]

287. Kaji, K.; Norrby, K.; Paca, A.; Mileikovsky, M.; Mohseni, P.; Woltjen, K. Virus-free induction of pluripotency and subsequent excision of reprogramming factors. Nature 2009, 458, 771-775. [CrossRef] [PubMed] 
288. Zhou, W.; Freed, C.R. Adenoviral gene delivery can reprogram human fibroblasts to induced pluripotent stem cells. Stem Cells 2009, 27, 2667-2674. [CrossRef] [PubMed]

289. Meraviglia, V.; Zanon, A.; Lavdas, A.A.; Schwienbacher, C.; Silipigni, R.; Di Segni, M.; Chen, H.S.; Pramstaller, P.P.; Hicks, A.A.; Rossini, A. Generation of induced pluripotent stem cells from frozen buffy coats using non-integrating episomal plasmids. J. Vis. Exp. 2015, 100, e52885. [CrossRef]

290. Okita, K.; Nakagawa, M.; Hyenjong, H.; Ichisaka, T.; Yamanaka, S. Generation of mouse induced pluripotent stem cells without viral vectors. Science 2008, 322, 949-953. [CrossRef]

291. Fusaki, N.; Ban, H.; Nishiyama, A.; Saeki, K.; Hasegawa, M. Efficient induction of transgene-free human pluripotent stem cells using a vector based on Sendai virus, an RNA virus that does not integrate into the host genome. Proc. Acad. Ser. B 2009, 85, 348-362. [CrossRef] [PubMed]

292. Judson, R.L.; Babiarz, J.E.; Venere, M.; Blelloch, R. Embryonic stem cell-specific microRNAs promote induced pluripotency. Nat. Biotechnol. 2009, 27, 459-461. [CrossRef] [PubMed]

293. Card, D.A.; Hebbar, P.B.; Li, L.; Trotter, K.W.; Komatsu, Y.; Mishina, Y.; Archer, T.K. Oct4/Sox2-regulated miR-302 targets cyclin D1 in human embryonic stem cells. Mol. Cell. Biol. 2008, 28, 6426-6438. [CrossRef] [PubMed]

294. Anokye-Danso, F.; Trivedi, C.M.; Juhr, D.; Gupta, M.; Cui, Z.; Tian, Y.; Zhang, Y.; Yang, W.; Gruber, P.J.; Epstein, J.A.; et al. Highly efficient miRNA-mediated reprogramming of mouse and human somatic cells to pluripotency. Cell Stem Cell 2011, 8, 376-388. [CrossRef] [PubMed]

295. Schlaeger, T.M.; Daheron, L.; Brickler, T.R.; Entwisle, S.; Chan, K.; Cianci, A.; DeVine, A.; Ettenger, A.; Fitzgerald, K.; Godfrey, M.; et al. A comparison of non-integrating reprogramming methods. Nat. Biotechnol. 2015, 33, 58-63. [CrossRef] [PubMed]

296. Freberg, C.T.; Dahl, J.A.; Timoskainen, S.; Collas, P. Epigenetic reprogramming of OCT4 and NANOG regulatory regions by embryonal carcinoma cell extract. Mol. Biol. Cell 2007, 18, 1543-1553. [CrossRef] [PubMed]

297. Kim, D.; Kim, C.H.; Moon, J.I.; Chung, Y.G.; Chang, M.Y.; Han, B.S.; Ko, S.; Yang, E.; Cha, K.Y.; Lanza, R.; et al. Generation of human induced pluripotent stem cells by direct delivery of reprogramming proteins. Cell Stem Cell 2009, 4, 472-476. [CrossRef]

298. Huangfu, D.; Maehr, R.; Guo, W.; Eijkelenboom, A.; Snitow, M.; Chen, A.E.; Melton, D.A. Induction of pluripotent stem cells by defined factors is greatly improved by small-molecule compounds. Nat. Biotechnol. 2008, 26, 795-797. [CrossRef]

299. Li, W.; Ding, S. Small molecules that modulate embryonic stem cell fate and somatic cell reprogramming. Trends Pharmacol. Sci. 2010, 31, 36-45. [CrossRef]

300. Bru, T.; Clarke, C.; McGrew, M.J.; Sang, H.M.; Wilmut, I.; Blow, J.J. Rapid induction of pluripotency genes after exposure of human somatic cells to mouse ES cell extracts. Exp. Cell Res. 2008, 314, 2634-2642. [CrossRef]

301. Konermann, S.; Brigham, M.D.; Trevino, A.E.; Joung, J.; Abudayyeh, O.O.; Barcena, C.; Hsu, P.D.; Habib, N.; Gootenberg, J.S.; Nishimasu, H.; et al. Genome-scale transcriptional activation by an engineered CRISPR-Cas9 complex. Nature 2015, 517, 583-588. [CrossRef] [PubMed]

302. Weltner, J.; Balboa, D.; Katayama, S.; Bespalov, M.; Krjutskov, K.; Jouhilahti, E.M.; Trokovic, R.; Kere, J.; Otonkoski, T. Human pluripotent reprogramming with CRISPR activators. Nat. Commun. 2018, 9, 2643. [CrossRef] [PubMed]

303. Jinek, M.; Chylinski, K.; Fonfara, I.; Hauer, M.; Doudna, J.A.; Charpentier, E. A programmable dual-RNA-guided DNA endonuclease in adaptive bacterial immunity. Science 2012, 337, 816-821. [CrossRef]

304. Zetsche, B.; Gootenberg, J.S.; Abudayyeh, O.O.; Slaymaker, I.M.; Makarova, K.S.; Essletzbichler, P.; Volz, S.E.; Joung, J.; van der Oost, J.; Regev, A.; et al. Cpf1 is a single RNA-guided endonuclease of a class 2 CRISPR-Cas system. Cell 2015, 163, 759-771. [CrossRef] [PubMed]

305. Joung, J.K.; Sander, J.D. TALENs: A widely applicable technology for targeted genome editing. Nat. Rev. Mol. Cell Biol. 2013, 14, 49-55. [CrossRef] [PubMed]

306. Nemudryi, A.A.; Valetdinova, K.R.; Medvedev, S.P.; Zakian, S.M. TALEN and CRISPR/Cas genome editing systems: Tools of discovery. Acta Nat. 2014, 6, 19-40. [CrossRef]

307. Debus, J.D.; Milting, H.; Brodehl, A.; Kassner, A.; Anselmetti, D.; Gummert, J.; Gaertner-Rommel, A. In vitro analysis of arrhythmogenic cardiomyopathy associated desmoglein-2 (DSG2) mutations reveals diverse glycosylation patterns. J. Mol. Cell. Cardiol. 2019, 129, 303-313. [CrossRef] [PubMed] 
308. Sharma, A.; Toepfer, C.N.; Schmid, M.; Garfinkel, A.C.; Seidman, C.E. Differentiation and contractile analysis of GFP-sarcomere reporter hiPSC-cardiomyocytes. Curr. Protoc. Hum. Genet. 2018, 96, 21.12.1-21.12.12. [CrossRef] [PubMed]

309. Matsa, E.; Dixon, J.E.; Medway, C.; Georgiou, O.; Patel, M.J.; Morgan, K.; Kemp, P.J.; Staniforth, A.; Mellor, I.; Denning, C. Allele-specific RNA interference rescues the long-QT syndrome phenotype in human-induced pluripotency stem cell cardiomyocytes. Eur. Heart J. 2014, 35, 1078-1087. [CrossRef] [PubMed]

310. Dzilic, E.; Lahm, H.; Dressen, M.; Deutsch, M.A.; Lange, R.; Wu, S.M.; Krane, M.; Doppler, S.A. Genome editing redefines precision medicine in the cardiovascular field. Stem Cells Int. 2018, 2018, 4136473. [CrossRef]

311. Gallagher, D.N.; Haber, J.E. Repair of a site-specific DNA cleavage: Old-school lessons for Cas9-mediated gene editing. ACS Chem. Biol. 2018, 13, 397-405. [CrossRef] [PubMed]

312. Wei, H.; Zhang, X.H.; Clift, C.; Yamaguchi, N.; Morad, M. CRISPR/Cas9 Gene editing of RyR2 in human stem cell-derived cardiomyocytes provides a novel approach in investigating dysfunctional $\mathrm{Ca}(2+)$ signaling. Cell Calcium 2018, 73, 104-111. [CrossRef] [PubMed]

313. Anderson, D.M.; Anderson, K.M.; Chang, C.L.; Makarewich, C.A.; Nelson, B.R.; McAnally, J.R.; Kasaragod, P.; Shelton, J.M.; Liou, J.; Bassel-Duby, R.; et al. A micropeptide encoded by a putative long noncoding RNA regulates muscle performance. Cell 2015, 160, 595-606. [CrossRef] [PubMed]

314. Roberts, B.; Hendershott, M.C.; Arakaki, J.; Gerbin, K.A.; Malik, H.; Nelson, A.; Gehring, J.; Hookway, C.; Ludmann, S.A.; Yang, R.; et al. Fluorescent gene tagging of transcriptionally silent genes in hiPSCs. Stem Cell Rep. 2019, 12, 1145-1158. [CrossRef] [PubMed]

315. Xiang, X.; Li, C.; Chen, X.; Dou, H.; Li, Y.; Zhang, X.; Luo, Y. CRISPR/Cas9-mediated gene tagging: A step-by-step protocol. Methods Mol. Biol. 2019, 1961, 255-269. [PubMed]

316. Haupt, A.; Grancharova, T.; Arakaki, J.; Fuqua, M.A.; Roberts, B.; Gunawardane, R.N. Endogenous protein tagging in human induced pluripotent stem cells using CRISPR/Cas9. J. Vis. Exp. 2018, 138, e58130. [CrossRef]

317. Liu, M.; Rehman, S.; Tang, X.; Gu, K.; Fan, Q.; Chen, D.; Ma, W. Methodologies for Improving HDR efficiency. Front. Genet. 2018, 9, 691. [CrossRef] [PubMed]

318. Smirnikhina, S.A.; Anuchina, A.A.; Lavrov, A.V. Ways of improving precise knock-in by genome-editing technologies. Hum. Genet. 2019, 138, 1-19. [CrossRef]

319. Pawelczak, K.S.; Gavande, N.S.; VanderVere-Carozza, P.S.; Turchi, J.J. Modulating DNA repair pathways to improve precision genome engineering. ACS Chem. Biol. 2018, 13, 389-396. [CrossRef]

320. Gu, B.; Posfai, E.; Rossant, J. Efficient generation of targeted large insertions by microinjection into two-cell-stage mouse embryos. Nat. Biotechnol. 2018, 36, 632-637. [CrossRef]

321. Savic, N.; Ringnalda, F.C.; Lindsay, H.; Berk, C.; Bargsten, K.; Li, Y.; Neri, D.; Robinson, M.D.; Ciaudo, C.; Hall, J.; et al. Covalent linkage of the DNA repair template to the CRISPR-Cas9 nuclease enhances homology-directed repair. eLife 2018, 7, e33761. [CrossRef] [PubMed]

322. Savic, N.; Ringnalda, F.C.; Berk, C.; Bargsten, K.; Hall, J.; Jinek, M.; Schwank, G. In vitro generation of CRISPR-Cas9 complexes with covalently bound repair templates for genome editing in mammalian cells. Bio Protoc. 2019, 9, e3136. [CrossRef] [PubMed]

323. Komor, A.C.; Kim, Y.B.; Packer, M.S.; Zuris, J.A.; Liu, D.R. Programmable editing of a target base in genomic DNA without double-stranded DNA cleavage. Nature 2016, 533, 420-424. [CrossRef] [PubMed]

324. Zafra, M.P.; Schatoff, E.M.; Katti, A.; Foronda, M.; Breinig, M.; Schweitzer, A.Y.; Simon, A.; Han, T.; Goswami, S.; Montgomery, E.; et al. Optimized base editors enable efficient editing in cells, organoids and mice. Nat. Biotechnol. 2018, 36, 888-893. [CrossRef] [PubMed]

325. Villiger, L.; Grisch-Chan, H.M.; Lindsay, H.; Ringnalda, F.; Pogliano, C.B.; Allegri, G.; Fingerhut, R.; Haberle, J.; Matos, J.; Robinson, M.D.; et al. Treatment of a metabolic liver disease by in vivo genome base editing in adult mice. Nat. Med. 2018, 24, 1519-1525. [CrossRef] [PubMed]

326. Carvalho, A.B.; de Carvalho, A.C. Heart regeneration: Past, present and future. World J. Cardiol. 2010, 2, 107-111. [CrossRef] [PubMed]

327. Claycomb, W.C.; Lanson, N.A., Jr.; Stallworth, B.S.; Egeland, D.B.; Delcarpio, J.B.; Bahinski, A.; Izzo, N.J., Jr. HL-1 cells: A cardiac muscle cell line that contracts and retains phenotypic characteristics of the adult cardiomyocyte. Proc. Natl. Acad. Sci. USA 1998, 95, 2979-2984. [CrossRef] [PubMed]

328. Mazzotta, S.; Lynch, A.T.; Hoppler, S. Cardiomyocyte differentiation from human embryonic stem cells. Methods Mol. Biol. 2018, 1816, 67-78. [PubMed] 
329. Hatani, T.; Miki, K.; Yoshida, Y. Induction of human induced pluripotent stem cells to cardiomyocytes using embryoid bodies. Methods Mol. Biol. 2018, 1816, 79-92.

330. Zhang, J.; Wilson, G.F.; Soerens, A.G.; Koonce, C.H.; Yu, J.; Palecek, S.P.; Thomson, J.A.; Kamp, T.J. Functional cardiomyocytes derived from human induced pluripotent stem cells. Circ. Res. 2009, 104, e30-e41. [CrossRef]

331. Pesl, M.; Acimovic, I.; Pribyl, J.; Hezova, R.; Vilotic, A.; Fauconnier, J.; Vrbsky, J.; Kruzliak, P.; Skladal, P.; Kara, T.; et al. Forced aggregation and defined factors allow highly uniform-sized embryoid bodies and functional cardiomyocytes from human embryonic and induced pluripotent stem cells. Heart Vessels 2014, 29, 834-846. [CrossRef] [PubMed]

332. Yokoo, N.; Baba, S.; Kaichi, S.; Niwa, A.; Mima, T.; Doi, H.; Yamanaka, S.; Nakahata, T.; Heike, T. The effects of cardioactive drugs on cardiomyocytes derived from human induced pluripotent stem cells. Biochem. Biophys. Res. Commun. 2009, 387, 482-488. [CrossRef] [PubMed]

333. Zwi, L.; Caspi, O.; Arbel, G.; Huber, I.; Gepstein, A.; Park, I.H.; Gepstein, L. Cardiomyocyte differentiation of human induced pluripotent stem cells. Circulation 2009, 120, 1513-1523. [CrossRef] [PubMed]

334. Burridge, P.W.; Thompson, S.; Millrod, M.A.; Weinberg, S.; Yuan, X.; Peters, A.; Mahairaki, V.; Koliatsos, V.E.; Tung, L.; Zambidis, E.T. A universal system for highly efficient cardiac differentiation of human induced pluripotent stem cells that eliminates interline variability. PLoS ONE 2011, 6, e18293. [CrossRef] [PubMed]

335. Mummery, C.L.; Zhang, J.; Ng, E.S.; Elliott, D.A.; Elefanty, A.G.; Kamp, T.J. Differentiation of human embryonic stem cells and induced pluripotent stem cells to cardiomyocytes: A methods overview. Circ. Res. 2012, 111, 344-358. [CrossRef] [PubMed]

336. Besser, R.R.; Ishahak, M.; Mayo, V.; Carbonero, D.; Claure, I.; Agarwal, A. Engineered microenvironments for maturation of stem cell derived cardiac myocytes. Theranostics 2018, 8, 124-140. [CrossRef] [PubMed]

337. Tzahor, E. Wnt/beta-catenin signaling and cardiogenesis: Timing does matter. Dev. Cell 2007, 13, 10-13. [CrossRef] [PubMed]

338. Nakajima, Y.; Yamagishi, T.; Hokari, S.; Nakamura, H. Mechanisms involved in valvuloseptal endocardial cushion formation in early cardiogenesis: Roles of transforming growth factor (TGF)- $\beta$ and bone morphogenetic protein (BMP). Anat. Rec. 2000, 258, 119-127. [CrossRef]

339. Mably, J.D.; Liew, C.C. Factors involved in cardiogenesis and the regulation of cardiac-specific gene expression. Circ. Res. 1996, 79, 4-13. [CrossRef]

340. Govindsamy, A.; Naidoo, S.; Cerf, M.E. Cardiac development and transcription factors: Insulin signalling, insulin resistance, and intrauterine nutritional programming of cardiovascular disease. J. Nutr. Metab. 2018, 2018, 8547976. [CrossRef]

341. Yan, S.; Jiao, K. Functions of miRNAs during mammalian heart development. Int. J. Mol. Sci. 2016, 17, 789. [CrossRef]

342. Rajala, K.; Pekkanen-Mattila, M.; Aalto-Setala, K. Cardiac differentiation of pluripotent stem cells. Stem Cells Int. 2011, 2011, 383709. [CrossRef] [PubMed]

343. Yassa, M.E.; Mansour, I.A.; Sewelam, N.I.; Hamza, H.; Gaafar, T. The impact of growth factors on human induced pluripotent stem cells differentiation into cardiomyocytes. Life Sci. 2018, 196, 38-47. [CrossRef] [PubMed]

344. Kim, M.S.; Horst, A.; Blinka, S.; Stamm, K.; Mahnke, D.; Schuman, J.; Gundry, R.; Tomita-Mitchell, A.; Lough, J. Activin-A and Bmp4 levels modulate cell type specification during CHIR-induced cardiomyogenesis. PLoS ONE 2015, 10, e0118670. [CrossRef] [PubMed]

345. Fonoudi, H.; Ansari, H.; Abbasalizadeh, S.; Larijani, M.R.; Kiani, S.; Hashemizadeh, S.; Zarchi, A.S.; Bosman, A.; Blue, G.M.; Pahlavan, S.; et al. A universal and robust integrated platform for the scalable production of human cardiomyocytes from pluripotent stem cells. Stem Cells Transl. Med. 2015, 4, 1482-1494. [CrossRef]

346. Hemmi, N.; Tohyama, S.; Nakajima, K.; Kanazawa, H.; Suzuki, T.; Hattori, F.; Seki, T.; Kishino, Y.; Hirano, A.; Okada, M.; et al. A massive suspension culture system with metabolic purification for human pluripotent stem cell-derived cardiomyocytes. Life Sci. 2014, 3, 1473-1483. [CrossRef] [PubMed]

347. Burridge, P.W.; Holmstrom, A.; Wu, J.C. Chemically defined culture and cardiomyocyte differentiation of human pluripotent stem cells. Curr. Protoc. Hum. Genet. 2015, 87, 21.3.1-21.3.15.

348. Zhao, Y.; Rafatian, N.; Feric, N.T.; Cox, B.J.; Aschar-Sobbi, R.; Wang, E.Y.; Aggarwal, P.; Zhang, B.; Conant, G.; Ronaldson-Bouchard, K.; et al. A platform for generation of chamber-specific cardiac tissues and disease modeling. Cell 2019, 176, 913-927.e18. [CrossRef] 
349. Talkhabi, M.; Aghdami, N.; Baharvand, H. Human cardiomyocyte generation from pluripotent stem cells: A state-of-art. Life Sci. 2016, 145, 98-113. [CrossRef]

350. Fatima, A.; Xu, G.; Shao, K.; Papadopoulos, S.; Lehmann, M.; Arnaiz-Cot, J.J.; Rosa, A.O.; Nguemo, F.; Matzkies, M.; Dittmann, S.; et al. In vitro modeling of ryanodine receptor 2 dysfunction using human induced pluripotent stem cells. Cell. Physiol. Biochem. 2011, 28, 579-592. [CrossRef]

351. Pradhapan, P.; Kuusela, J.; Viik, J.; Aalto-Setala, K.; Hyttinen, J. Cardiomyocyte MEA data analysis (CardioMDA) - A novel field potential data analysis software for pluripotent stem cell derived cardiomyocytes. PLoS ONE 2013, 8, e73637. [CrossRef] [PubMed]

352. Penttinen, K.; Siirtola, H.; Avalos-Salguero, J.; Vainio, T.; Juhola, M.; Aalto-Setala, K. Novel analysis software for detecting and classifying Ca2+ transient abnormalities in stem cell-derived cardiomyocytes. PLoS ONE 2015, 10, e0135806. [CrossRef] [PubMed]

353. Tsurumi, F.; Baba, S.; Yoshinaga, D.; Umeda, K.; Hirata, T.; Takita, J.; Heike, T. The intracellular Ca2+ concentration is elevated in cardiomyocytes differentiated from hiPSCs derived from a Duchenne muscular dystrophy patient. PLoS ONE 2019, 14, e0213768. [CrossRef]

354. Ahola, A.; Polonen, R.P.; Aalto-Setala, K.; Hyttinen, J. Simultaneous measurement of contraction and calcium transients in stem cell derived cardiomyocytes. Ann. Biomed. Eng. 2018, 46, 148-158. [CrossRef]

355. Hortigon-Vinagre, M.P.; Zamora, V.; Burton, F.L.; Green, J.; Gintant, G.A.; Smith, G.L. The use of ratiometric fluorescence measurements of the voltage sensitive dye Di-4-ANEPPS to examine action potential characteristics and drug effects on human induced pluripotent stem cell-derived cardiomyocytes. Toxicol. Sci. 2016, 154, 320-331. [CrossRef] [PubMed]

356. Wheelwright, M.; Win, Z.; Mikkila, J.L.; Amen, K.Y.; Alford, P.W.; Metzger, J.M. Investigation of human Ipsc-derived cardiac myocyte functional maturation by single cell traction force microscopy. PLoS ONE 2018, 13, e0194909. [CrossRef]

357. Pesl, M.; Pribyl, J.; Acimovic, I.; Vilotic, A.; Jelinkova, S.; Salykin, A.; Lacampagne, A.; Dvorak, P.; Meli, A.C.; Skladal, P.; et al. Atomic force microscopy combined with human pluripotent stem cell derived cardiomyocytes for biomechanical sensing. Biosens. Bioelectron. 2016, 85, 751-757. [CrossRef]

358. Liu, J.; Sun, N.; Bruce, M.A.; Wu, J.C.; Butte, M.J. Atomic force mechanobiology of pluripotent stem cell-derived cardiomyocytes. PLoS ONE 2012, 7, e37559. [CrossRef]

359. Feaster, T.K.; Cadar, A.G.; Wang, L.; Williams, C.H.; Chun, Y.W.; Hempel, J.E.; Bloodworth, N.; Merryman, W.D.; Lim, C.C.; Wu, J.C.; et al. Matrigel mattress: A method for the generation of single contracting human-induced pluripotent stem cell-derived cardiomyocytes. Circ. Res. 2015, 117, 995-1000. [CrossRef]

360. Carvajal-Vergara, X.; Sevilla, A.; D'Souza, S.L.; Ang, Y.S.; Schaniel, C.; Lee, D.F.; Yang, L.; Kaplan, A.D.; Adler, E.D.; Rozov, R.; et al. Patient-specific induced pluripotent stem-cell-derived models of LEOPARD syndrome. Nature 2010, 465, 808-812. [CrossRef]

361. Digilio, M.C.; Conti, E.; Sarkozy, A.; Mingarelli, R.; Dottorini, T.; Marino, B.; Pizzuti, A.; Dallapiccola, B. Grouping of multiple-lentigines/LEOPARD and Noonan syndromes on the PTPN11 gene. Am. J. Hum. Genet. 2002, 71, 389-394. [CrossRef] [PubMed]

362. Ganigara, M.; Prabhu, A.; Kumar, R.S. LEOPARD syndrome in an infant with severe hypertrophic cardiomyopathy and PTPN11 mutation. Ann. Pediatr. Cardiol. 2011, 4, 74-76. [CrossRef] [PubMed]

363. Limongelli, G.; Pacileo, G.; Russo, M.G.; Sarkozy, A.; Felicetti, M.; Di Salvo, G.; Morelli, C.; Calabro, P.; Paladini, D.; Marino, B.; et al. Severe, early onset hypertrophic cardiomyopathy in a family with LEOPARD syndrome. J. Prenat. Med. 2008, 2, 24-26.

364. Molkentin, J.D. Calcineurin-NFAT signaling regulates the cardiac hypertrophic response in coordination with the MAPKs. Cardiovasc. Res. 2004, 63, 467-475. [CrossRef] [PubMed]

365. Adamcova, M.; Skarkova, V.; Seifertova, J.; Rudolf, E. Cardiac troponins are among targets of doxorubicin-induced cardiotoxicity in hiPCS-CMs. Int. J. Mol. Sci. 2019, 20, 2638. [CrossRef]

366. Lu, Y.; Bu, M.; Yun, H. Sevoflurane prevents hypoxia/reoxygenation-induced cardiomyocyte apoptosis by inhibiting PI3KC3-mediated autophagy. Hum. Cell 2019, 32, 150-159. [CrossRef] [PubMed]

367. Naftali-Shani, N.; Molotski, N.; Nevo-Caspi, Y.; Arad, M.; Kuperstein, R.; Amit, U.; Huber, I.; Zeltzer, L.A.; Levich, A.; Abbas, H.; et al. Modeling peripartum cardiomyopathy with human induced pluripotent stem cells reveals distinctive abnormal function of cardiomyocytes. Circulation 2018, 138, 2721-2723. [CrossRef] 
368. Graneli, C.; Hicks, R.; Brolen, G.; Synnergren, J.; Sartipy, P. Diabetic cardiomyopathy modelling using induced pluripotent stem cell derived cardiomyocytes: Recent advances and emerging models. Stem Cell Rev. 2019, 15, 13-22. [CrossRef]

369. Drawnel, F.M.; Boccardo, S.; Prummer, M.; Delobel, F.; Graff, A.; Weber, M.; Gerard, R.; Badi, L.; Kam-Thong, T.; $\mathrm{Bu}, \mathrm{L} . ;$ et al. Disease modeling and phenotypic drug screening for diabetic cardiomyopathy using human induced pluripotent stem cells. Cell Rep. 2014, 9, 810-821. [CrossRef]

370. Ng, K.M.; Lau, Y.M.; Dhandhania, V.; Cai, Z.J.; Lee, Y.K.; Lai, W.H.; Tse, H.F.; Siu, C.W. Empagliflozin ammeliorates high glucose induced-cardiac dysfuntion in human iPSC-derived cardiomyocytes. Sci. Rep. 2018, 8, 14872. [CrossRef]

371. Pant, T.; Mishra, M.K.; Bai, X.; Ge, Z.D.; Bosnjak,Z.J.; Dhanasekaran, A. Microarray analysis of long non-coding RNA and mRNA expression profiles in diabetic cardiomyopathy using human induced pluripotent stem cell-derived cardiomyocytes. Diabetes Vasc. Dis. Res. 2019, 16, 57-68. [CrossRef]

372. Bozzi, A.; Sayed, N.; Matsa, E.; Sass, G.; Neofytou, E.; Clemons, K.V.; Correa-Oliveira, R.; Stevens, D.A.; $\mathrm{Wu}$, J.C. Using human induced pluripotent stem cell-derived cardiomyocytes as a model to study Trypanosoma cruzi infection. Stem Cell Rep. 2019, 12, 1232-1241. [CrossRef] [PubMed]

373. Sharma, A.; Marceau, C.; Hamaguchi, R.; Burridge, P.W.; Rajarajan, K.; Churko, J.M.; Wu, H.; Sallam, K.I.; Matsa, E.; Sturzu, A.C.; et al. Human induced pluripotent stem cell-derived cardiomyocytes as an in vitro model for coxsackievirus B3-induced myocarditis and antiviral drug screening platform. Circ. Res. 2014, 115, 556-566. [CrossRef] [PubMed]

374. Judge, L.M.; Perez-Bermejo, J.A.; Truong, A.; Ribeiro, A.J.; Yoo,J.C.; Jensen, C.L.; Mandegar, M.A.; Huebsch, N.; Kaake, R.M.; So, P.L.; et al. A BAG3 chaperone complex maintains cardiomyocyte function during proteotoxic stress. JCI Insight 2017, 2, e94623. [CrossRef] [PubMed]

375. Ma, N.; Zhang, J.; Itzhaki, I.; Zhang, S.L.; Chen, H.; Haddad, F.; Kitani, T.; Wilson, K.D.; Tian, L.; Shrestha, R.; et al. Determining the pathogenicity of a genomic variant of uncertain significance using CRISPR/Cas9 and human-induced pluripotent stem cells. Circulation 2018, 138, 2666-2681. [CrossRef]

376. Bezzerides, V.J.; Caballero, A.; Wang, S.; Ai, Y.; Hylind, R.J.; Lu, F.; Heims-Waldron, D.A.; Chambers, K.D.; Zhang, D.; Abrams, D.J.; et al. Gene therapy for catecholaminergic polymorphic ventricular tachycardia by inhibition of $\mathrm{Ca}(2+) /$ calmodulin-dependent kinase II. Circulation 2019, 140, 405-419. [CrossRef] [PubMed]

377. Gramlich, M.; Pane, L.S.; Zhou, Q.; Chen, Z.; Murgia, M.; Schotterl, S.; Goedel, A.; Metzger, K.; Brade, T.; Parrotta, E.; et al. Antisense-mediated exon skipping: A therapeutic strategy for titin-based dilated cardiomyopathy. EMBO Mol. Med. 2015, 7, 562-576. [CrossRef]

378. Van Heesch, S.; Witte, F.; Schneider-Lunitz, V.; Schulz, J.F.; Adami, E.; Faber, A.B.; Kirchner, M.; Maatz, H.; Blachut, S.; Sandmann, C.L.; et al. The translational landscape of the human heart. Cell 2019, 178, 242-260.e29. [CrossRef]

379. Kyrychenko, V.; Kyrychenko, S.; Tiburcy, M.; Shelton, J.M.; Long, C.; Schneider, J.W.; Zimmermann, W.H.; Bassel-Duby, R.; Olson, E.N. Functional correction of dystrophin actin binding domain mutations by genome editing. JCI Insight 2017, 2, e95918. [CrossRef]

380. Smith, J.G.W.; Owen, T.; Bhagwan, J.R.; Mosqueira, D.; Scott, E.; Mannhardt, I.; Patel, A.; Barriales-Villa, R.; Monserrat, L.; Hansen, A.; et al. Isogenic pairs of hiPSC-CMs with hypertrophic cardiomyopathy/LVNCassociated ACTC1 E99K mutation unveil differential functional deficits. Stem Cell Rep. 2018, 11, 1226-1243. [CrossRef]

381. Phelan, D.G.; Anderson, D.J.; Howden, S.E.; Wong, R.C.; Hickey, P.F.; Pope, K.; Wilson, G.R.; Pebay, A.; Davis, A.M.; Petrou, S.; et al. ALPK3-deficient cardiomyocytes generated from patient-derived induced pluripotent stem cells and mutant human embryonic stem cells display abnormal calcium handling and establish that ALPK3 deficiency underlies familial cardiomyopathy. Eur. Heart J. 2016, 37, 2586-2590. [CrossRef] [PubMed]

382. Josowitz, R.; Mulero-Navarro, S.; Rodriguez, N.A.; Falce, C.; Cohen, N.; Ullian, E.M.; Weiss, L.A.; Rauen, K.A.; Sobie, E.A.; Gelb, B.D. Autonomous and Non-autonomous defects underlie hypertrophic cardiomyopathy in BRAF-mutant hiPSC-derived cardiomyocytes. Stem Cell Rep. 2016, 7, 355-369. [CrossRef] [PubMed]

383. Meraviglia, V.; Benzoni, P.; Landi, S.; Murano, C.; Langione, M.; Motta, B.M.; Baratto, S.; Silipigni, R.; Di Segni, M.; Pramstaller, P.P.; et al. Generation of human induced pluripotent stem cells (EURACi001-A, EURACi002-A, EURACi003-A) from peripheral blood mononuclear cells of three patients carrying mutations in the CAV3 gene. Stem Cell Res. 2018, 27, 25-29. [CrossRef] [PubMed] 
384. Mitzelfelt, K.A.; Limphong, P.; Choi, M.J.; Kondrat, F.D.; Lai, S.; Kolander, K.D.; Kwok, W.M.; Dai, Q.; Grzybowski, M.N.; Zhang, H.; et al. The human 343delT HSPB5 chaperone associated with early-onset skeletal myopathy causes defects in protein solubility. J. Biol. Chem. 2016, 291, 14939-14953. [CrossRef] [PubMed]

385. Fatima, A.; Dittmann, S.; Kaifeng, S.; Linke, M.; Zechner, U.; Hennies, H.C.; Stork, I.; Rosenkranz, S.; Farr, M.; Milting, H.; et al. Derivation of induced pluripotent stem (iPS) cells from a patient with an arrhythmogenic right ventricular cardiomyopathy (ARVC). J. Stem Cells Regen. Med. 2010, 6, 97. [PubMed]

386. Khudiakov, A.; Kostina, D.; Zlotina, A.; Nikulina, T.; Sergushichev, A.; Gudkova, A.; Tomilin, A.; Malashicheva, A.; Kostareva, A. Generation of iPSC line from desmin-related cardiomyopathy patient carrying splice site mutation of DES gene. Stem Cell Res. 2017, 24, 77-80. [CrossRef]

387. Tse, H.F.; Ho, J.C.; Choi, S.W.; Lee, Y.K.; Butler, A.W.; Ng, K.M.; Siu, C.W.; Simpson, M.A.; Lai, W.H.; Chan, Y.C.; et al. Patient-specific induced-pluripotent stem cells-derived cardiomyocytes recapitulate the pathogenic phenotypes of dilated cardiomyopathy due to a novel DES mutation identified by whole exome sequencing. Hum. Mol. Genet. 2013, 22, 1395-1403. [CrossRef]

388. Eisen, B.; Ben Jehuda, R.; Cuttitta, A.J.; Mekies, L.N.; Shemer, Y.; Baskin, P.; Reiter, I.; Willi, L.; Freimark, D.; Gherghiceanu, M.; et al. Electrophysiological abnormalities in induced pluripotent stem cell-derived cardiomyocytes generated from Duchenne muscular dystrophy patients. J. Cell. Mol. Med. 2019, 23, 2125-2135. [CrossRef]

389. Pioner, J.M.; Guan, X.; Klaiman, J.M.; Racca, A.W.; Pabon, L.; Muskheli, V.; Macadangdang, J.; Ferrantini, C.; Hoopmann, M.R.; Moritz, R.L.; et al. Absence of full-length dystrophin impairs normal maturation and contraction of cardiomyocytes derived from human induced pluripotent stem cells. Cardiovasc. Res. 2019. [CrossRef]

390. Guan, X.; Mack, D.L.; Moreno, C.M.; Strande, J.L.; Mathieu, J.; Shi, Y.; Markert, C.D.; Wang, Z.; Liu, G.; Lawlor, M.W.; et al. Dystrophin-deficient cardiomyocytes derived from human urine: New biologic reagents for drug discovery. Stem Cell Res. 2014, 12, 467-480. [CrossRef] [PubMed]

391. El-Battrawy, I.; Zhao, Z.; Lan, H.; Cyganek, L.; Tombers, C.; Li, X.; Buljubasic, F.; Lang, S.; Tiburcy, M.; Zimmermann, W.H.; et al. Electrical dysfunctions in human-induced pluripotent stem cell-derived cardiomyocytes from a patient with an arrhythmogenic right ventricular cardiomyopathy. Europace 2018, 20, f46-f56. [CrossRef] [PubMed]

392. Ng, R.; Manring, H.R.; Papoutsidakis, N.; Albertelli, T.; Tsai, N.; See, C.; Li, X.; Park, J.; Stevens, T.L.; Bobbili, P.J.; et al. Patient mutations linked to arrhythmogenic cardiomyopathy enhance calpain-mediated desmoplakin degradation. JCI Insight 2019, 4, e128643. [CrossRef] [PubMed]

393. Klein, S.; Dvornik, J.L.; Yarrabothula, A.R.; Schaniel, C. A Marfan syndrome human induced pluripotent stem cell line with a heterozygous FBN1 c.4082G > A mutation, ISMMSi002-B, for disease modeling. Stem Cell Res. 2017, 23, 73-76. [CrossRef] [PubMed]

394. El-Battrawy, I.; Zhao, Z.; Lan, H.; Li, X.; Yucel, G.; Lang, S.; Sattler, K.; Schunemann, J.D.; Zimmermann, W.H.; Cyganek, L.; et al. Ion channel dysfunctions in dilated cardiomyopathy in limb-girdle muscular dystrophy. Circ. Genom. Precis. Med. 2018, 11, e001893. [CrossRef] [PubMed]

395. Lee, Y.K.; Ho, P.W.; Schick, R.; Lau, Y.M.; Lai, W.H.; Zhou, T.; Li, Y.; Ng, K.M.; Ho, S.L.; Esteban, M.A.; et al. Modeling of Friedreich ataxia-related iron overloading cardiomyopathy using patient-specific-induced pluripotent stem cells. Pflugers Arch. Eur. J. Physiol. 2014, 466, 1831-1844. [CrossRef] [PubMed]

396. Hick, A.; Wattenhofer-Donze, M.; Chintawar, S.; Tropel, P.; Simard, J.P.; Vaucamps, N.; Gall, D.; Lambot, L.; Andre, C.; Reutenauer, L.; et al. Neurons and cardiomyocytes derived from induced pluripotent stem cells as a model for mitochondrial defects in Friedreich's ataxia. Dis. Models Mech. 2013, 6, 608-621. [CrossRef] [PubMed]

397. Chien, Y.; Chou, S.J.; Chang, Y.L.; Leu, H.B.; Yang, Y.P.; Tsai, P.H.; Lai, Y.H.; Chen, K.H.; Chang, W.C.; Sung, S.H.; et al. Inhibition of arachidonate 12/15-lipoxygenase improves $\alpha$-galactosidase efficacy in iPSC-derived cardiomyocytes from fabry patients. Int. J. Mol. Sci. 2018, 19, 1480. [CrossRef] [PubMed]

398. Chou, S.J.; Yu, W.C.; Chang, Y.L.; Chen, W.Y.; Chang, W.C.; Chien, Y.; Yen, J.C.; Liu, Y.Y.; Chen, S.J.; Wang, C.Y.; et al. Energy utilization of induced pluripotent stem cell-derived cardiomyocyte in Fabry disease. Int. J. Cardiol. 2017, 232, 255-263. [CrossRef] 
399. Yoshida, S.; Nakanishi, C.; Okada, H.; Mori, M.; Yokawa, J.; Yoshimuta, T.; Ohta, K.; Konno, T.; Fujino, N.; Kawashiri, M.A.; et al. Characteristics of induced pluripotent stem cells from clinically divergent female monozygotic twins with Danon disease. J. Mol. Cell. Cardiol. 2018, 114, 234-242. [CrossRef]

400. Hashem, S.I.; Murphy, A.N.; Divakaruni, A.S.; Klos, M.L.; Nelson, B.C.; Gault, E.C.; Rowland, T.J.; Perry, C.N.; Gu, Y.; Dalton, N.D.; et al. Impaired mitophagy facilitates mitochondrial damage in Danon disease. J. Mol. Cell. Cardiol. 2017, 108, 86-94. [CrossRef]

401. Chi, C.; Leonard, A.; Knight, W.E.; Beussman, K.M.; Zhao, Y.; Cao, Y.; Londono, P.; Aune, E.; Trembley, M.A.; Small, E.M.; et al. LAMP-2B regulates human cardiomyocyte function by mediating autophagosome-lysosome fusion. Proc. Natl. Acad. Sci. USA 2019, 116, 556-565. [CrossRef] [PubMed]

402. Shah, D.; Virtanen, L.; Prajapati, C.; Kiamehr, M.; Gullmets, J.; West, G.; Kreutzer, J.; Pekkanen-Mattila, M.; Helio, T.; Kallio, P.; et al. Modeling of $L M N A$-related dilated cardiomyopathy using human induced pluripotent stem cells. Cells 2019, 8, 594. [CrossRef] [PubMed]

403. Ho, J.C.; Zhou, T.; Lai, W.H.; Huang, Y.; Chan, Y.C.; Li, X.; Wong, N.L.; Li, Y.; Au, K.W.; Guo, D.; et al. Generation of induced pluripotent stem cell lines from 3 distinct laminopathies bearing heterogeneous mutations in lamin A/C. Aging 2011, 3, 380-390. [CrossRef] [PubMed]

404. Siu, C.W.; Lee, Y.K.; Ho, J.C.; Lai, W.H.; Chan, Y.C.; Ng, K.M.; Wong, L.Y.; Au, K.W.; Lau, Y.M.; Zhang, J.; et al. Modeling of lamin $\mathrm{A} / \mathrm{C}$ mutation premature cardiac aging using patient-specific induced pluripotent stem cells. Aging 2012, 4, 803-822. [CrossRef]

405. Lee, Y.K.; Lau, Y.M.; Cai, Z.J.; Lai, W.H.; Wong, L.Y.; Tse, H.F.; Ng, K.M.; Siu, C.W. Modeling treatment response for lamin $\mathrm{A} / \mathrm{C}$ related dilated cardiomyopathy in human induced pluripotent stem cells. J. Am. Heart Assoc. 2017, 6, e005677. [CrossRef]

406. Salvarani, N.; Crasto, S.; Miragoli, M.; Bertero, A.; Paulis, M.; Kunderfranco, P.; Serio, S.; Forni, A.; Lucarelli, C.; Dal Ferro, M.; et al. The K219T-Lamin mutation induces conduction defects through epigenetic inhibition of SCN5A in human cardiac laminopathy. Nat. Commun. 2019, 10, 2267. [CrossRef]

407. Li, S.; Pan, H.; Tan, C.; Sun, Y.; Song, Y.; Zhang, X.; Yang, W.; Wang, X.; Li, D.; Dai, Y.; et al. Mitochondrial dysfunctions contribute to hypertrophic cardiomyopathy in patient iPSC-derived cardiomyocytes with MT-RNR2 mutation. Stem Cell Rep. 2018, 10, 808-821. [CrossRef] [PubMed]

408. Wu, H.; Yang, H.; Rhee, J.W.; Zhang, J.Z.; Lam, C.K.; Sallam, K.; Chang, A.C.Y.; Ma, N.; Lee, J.; Zhang, H.; et al. Modelling diastolic dysfunction in induced pluripotent stem cell-derived cardiomyocytes from hypertrophic cardiomyopathy patients. Eur. Heart J. 2019. [CrossRef] [PubMed]

409. Dementyeva, E.V.; Medvedev, S.P.; Kovalenko, V.R.; Vyatkin, Y.V.; Kretov, E.I.; Slotvitsky, M.M.; Shtokalo, D.N.; Pokushalov, E.A.; Zakian, S.M. Applying patient-specific induced pluripotent stem cells to create a model of hypertrophic cardiomyopathy. Biochemistry (Mosc) 2019, 84, 291-298. [CrossRef] [PubMed]

410. Dambrot, C.; Braam, S.R.; Tertoolen, L.G.; Birket, M.; Atsma, D.E.; Mummery, C.L. Serum supplemented culture medium masks hypertrophic phenotypes in human pluripotent stem cell derived cardiomyocytes. J. Cell. Mol. Med. 2014, 18, 1509-1518. [CrossRef]

411. Birket, M.J.; Ribeiro, M.C.; Kosmidis, G.; Ward, D.; Leitoguinho, A.R.; van de Pol, V.; Dambrot, C.; Devalla, H.D.; Davis, R.P.; Mastroberardino, P.G.; et al. Contractile defect caused by mutation in MYBPC3 revealed under conditions optimized for human PSC-cardiomyocyte function. Cell Rep. 2015, 13, 733-745. [CrossRef] [PubMed]

412. Holliday, M.; Ross, S.B.; Lim, S.; Semsarian, C. Generation of an induced pluripotent stem cell line from a hypertrophic cardiomyopathy patient with a pathogenic myosin binding protein C (MYBPC3) p.Arg502Trp mutation. Stem Cell Res. 2018, 33, 56-59. [CrossRef] [PubMed]

413. Cohn, R.; Thakar, K.; Lowe, A.; Ladha, F.A.; Pettinato, A.M.; Romano, R.; Meredith, E.; Chen, Y.S.; Atamanuk, K.; Huey, B.D.; et al. A contraction stress model of hypertrophic cardiomyopathy due to sarcomere mutations. Stem Cell Rep. 2019, 12, 71-83. [CrossRef] [PubMed]

414. Davis, J.; Davis, L.C.; Correll, R.N.; Makarewich, C.A.; Schwanekamp, J.A.; Moussavi-Harami, F.; Wang, D.; York, A.J.; Wu, H.; Houser, S.R.; et al. A tension-based model distinguishes hypertrophic versus dilated cardiomyopathy. Cell 2016, 165, 1147-1159. [CrossRef] [PubMed]

415. Seeger, T.; Shrestha, R.; Lam, C.K.; Chen, C.; McKeithan, W.L.; Lau, E.; Wnorowski, A.; McMullen, G.; Greenhaw, M.; Lee, J.; et al. A premature termination codon mutation in MYBPC3 causes hypertrophic cardiomyopathy via chronic activation of nonsense-mediated decay. Circulation 2019, 139, 799-811. [CrossRef] [PubMed] 
416. Tanaka, A.; Yuasa, S.; Mearini, G.; Egashira, T.; Seki, T.; Kodaira, M.; Kusumoto, D.; Kuroda, Y.; Okata, S.; Suzuki, T.; et al. Endothelin-1 induces myofibrillar disarray and contractile vector variability in hypertrophic cardiomyopathy-induced pluripotent stem cell-derived cardiomyocytes. J. Am. Heart Assoc. 2014, 3, e001263. [CrossRef] [PubMed]

417. Ojala, M.; Prajapati, C.; Polonen, R.P.; Rajala, K.; Pekkanen-Mattila, M.; Rasku, J.; Larsson, K.; Aalto-Setala, K. Mutation-specific phenotypes in hiPSC-derived cardiomyocytes carrying either myosin-binding protein $\mathrm{C}$ or $\alpha$-tropomyosin mutation for hypertrophic cardiomyopathy. Stem Cells Int. 2016, 2016, 1684792. [CrossRef] [PubMed]

418. Prajapati, C.; Ojala, M.; Aalto-Setala, K. Divergent effects of adrenaline in human induced pluripotent stem cell-derived cardiomyocytes obtained from hypertrophic cardiomyopathy. Dis. Models Mech. 2018, 11, dmm032896. [CrossRef]

419. Prondzynski, M.; Kramer, E.; Laufer, S.D.; Shibamiya, A.; Pless, O.; Flenner, F.; Muller, O.J.; Munch, J.; Redwood, C.; Hansen, A.; et al. Evaluation of MYBPC3 trans-splicing and gene replacement as therapeutic options in human iPSC-derived cardiomyocytes. Mol. Ther. Nucleic Acids 2017, 7, 475-486. [CrossRef]

420. Viswanathan, S.K.; Puckelwartz, M.J.; Mehta, A.; Ramachandra, C.J.A.; Jagadeesan, A.; Fritsche-Danielson, R.; Bhat, R.V.; Wong, P.; Kandoi, S.; Schwanekamp, J.A.; et al. Association of cardiomyopathy with MYBPC3 D389V and MYBPC3Delta25bpIntronic deletion in South Asian descendants. JAMA Cardiol. 2018, 3, 481-488. [CrossRef]

421. Mosqueira, D.; Mannhardt, I.; Bhagwan, J.R.; Lis-Slimak, K.; Katili, P.; Scott, E.; Hassan, M.; Prondzynski, M.; Harmer, S.C.; Tinker, A.; et al. CRISPR/Cas9 editing in human pluripotent stem cell-cardiomyocytes highlights arrhythmias, hypocontractility, and energy depletion as potential therapeutic targets for hypertrophic cardiomyopathy. Eur. Heart J. 2018, 39, 3879-3892. [CrossRef]

422. Ross, S.B.; Fraser, S.T.; Nowak, N.; Semsarian, C. Generation of induced pluripotent stem cells (iPSCs) from a hypertrophic cardiomyopathy patient with the pathogenic variant p.Val698Ala in $\beta$-myosin heavy chain (MYH7) gene. Stem Cell Res. 2017, 20, 88-90. [CrossRef] [PubMed]

423. Yang, K.C.; Breitbart, A.; De Lange, W.J.; Hofsteen, P.; Futakuchi-Tsuchida, A.; Xu, J.; Schopf, C.; Razumova, M.V.; Jiao, A.; Boucek, R.; et al. Novel adult-onset systolic cardiomyopathy due to MYH7 E848G mutation in patient-derived induced pluripotent stem cells. JACC Basic Transl. Sci. 2018, 3, 728-740. [CrossRef] [PubMed]

424. Pioner, J.M.; Racca, A.W.; Klaiman, J.M.; Yang, K.C.; Guan, X.; Pabon, L.; Muskheli, V.; Zaunbrecher, R.; Macadangdang, J.; Jeong, M.Y.; et al. Isolation and mechanical measurements of myofibrils from human induced pluripotent stem cell-derived cardiomyocytes. Stem Cell Rep. 2016, 6, 885-896. [CrossRef] [PubMed]

425. Holliday, M.; Ross, S.B.; Lim, S.; Mangala, M.; Hill, A.; Szappanos, H.C.; Hool, L.; Semsarian, C. Development of induced pluripotent stem cells from a patient with hypertrophic cardiomyopathy who carries the pathogenic myosin heavy chain 7 mutation p.Arg403Gln. Stem Cell Res. 2018, 33, 269-273. [CrossRef]

426. Lan, F.; Lee, A.S.; Liang, P.; Sanchez-Freire, V.; Nguyen, P.K.; Wang, L.; Han, L.; Yen, M.; Wang, Y.; Sun, N.; et al. Abnormal calcium handling properties underlie familial hypertrophic cardiomyopathy pathology in patient-specific induced pluripotent stem cells. Cell Stem Cell 2013, 12, 101-113. [CrossRef] [PubMed]

427. Han, L.; Li, Y.; Tchao, J.; Kaplan, A.D.; Lin, B.; Li, Y.; Mich-Basso, J.; Lis, A.; Hassan, N.; London, B.; et al. Study familial hypertrophic cardiomyopathy using patient-specific induced pluripotent stem cells. Cardiovasc. Res. 2014, 104, 258-269. [CrossRef]

428. Zhou, W.; Bos, J.M.; Ye, D.; Tester, D.J.; Hrstka, S.; Maleszewski, J.J.; Ommen, S.R.; Nishimura, R.A.; Schaff, H.V.; Kim, C.S.; et al. Induced pluripotent stem cell-derived cardiomyocytes from a patient with MYL2-R58Q-mediated apical hypertrophic cardiomyopathy show hypertrophy, myofibrillar disarray, and calcium perturbations. J. Cardiovasc. Transl. Res. 2019, 1-10. [CrossRef]

429. Ma, D.; Wei, H.; Lu, J.; Ho, S.; Zhang, G.; Sun, X.; Oh, Y.; Tan, S.H.; Ng, M.L.; Shim, W.; et al. Generation of patient-specific induced pluripotent stem cell-derived cardiomyocytes as a cellular model of arrhythmogenic right ventricular cardiomyopathy. Eur. Heart J. 2013, 34(15), 1122-1133. [CrossRef]

430. Kim, C.; Wong, J.; Wen, J.; Wang, S.; Wang, C.; Spiering, S.; Kan, N.G.; Forcales, S.; Puri, P.L.; Leone, T.C.; et al. Studying arrhythmogenic right ventricular dysplasia with patient-specific iPSCs. Nature 2013, 494, 105-110. [CrossRef] 
431. Martewicz, S.; Luni, C.; Serena, E.; Pavan, P.; Chen, H.V.; Rampazzo, A.; Elvassore, N. Transcriptomic characterization of a human in vitro model of arrhythmogenic cardiomyopathy under topological and mechanical stimuli. Ann. Biomed. Eng. 2019, 47, 852-865. [CrossRef] [PubMed]

432. Akdis, D.; Saguner, A.M.; Shah, K.; Wei, C.; Medeiros-Domingo, A.; von Eckardstein, A.; Luscher, T.F.; Brunckhorst, C.; Chen, H.S.V.; Duru, F. Sex hormones affect outcome in arrhythmogenic right ventricular cardiomyopathy/dysplasia: From a stem cell derived cardiomyocyte-based model to clinical biomarkers of disease outcome. Eur. Heart J. 2017, 38, 1498-1508. [CrossRef]

433. Caspi, O.; Huber, I.; Gepstein, A.; Arbel, G.; Maizels, L.; Boulos, M.; Gepstein, L. Modeling of arrhythmogenic right ventricular cardiomyopathy with human induced pluripotent stem cells. Circ. Cardiovasc. Genet. 2013, 6, 557-568. [CrossRef] [PubMed]

434. Khudiakov, A.; Kostina, D.; Zlotina, A.; Yany, N.; Sergushichev, A.; Pervunina, T.; Tomilin, A.; Kostareva, A.; Malashicheva, A. Generation of iPSC line from patient with arrhythmogenic right ventricular cardiomyopathy carrying mutations in PKP2 gene. Stem Cell Res. 2017, 24, 85-88. [CrossRef] [PubMed]

435. Ermon, B.; Volpato, C.B.; Cattelan, G.; Silipigni, R.; Di Segni, M.; Cantaloni, C.; Casella, M.; Pramstaller, P.P.; Pompilio, G.; Sommariva, E.; et al. Derivation of human induced pluripotent stem cell line EURACi004-A from skin fibroblasts of a patient with arrhythmogenic cardiomyopathy carrying the heterozygous PKP2 mutation c.2569_3018del50. Stem Cell Res. 2018, 32, 78-82. [CrossRef] [PubMed]

436. Ceholski, D.K.; Turnbull, I.C.; Kong, C.W.; Koplev, S.; Mayourian, J.; Gorski, P.A.; Stillitano, F.; Skodras, A.A.; Nonnenmacher, M.; Cohen, N.; et al. Functional and transcriptomic insights into pathogenesis of R9C phospholamban mutation using human induced pluripotent stem cell-derived cardiomyocytes. J. Mol. Cell. Cardiol. 2018, 119, 147-154. [CrossRef]

437. Karakikes, I.; Stillitano, F.; Nonnenmacher, M.; Tzimas, C.; Sanoudou, D.; Termglinchan, V.; Kong, C.W.; Rushing, S.; Hansen, J.; Ceholski, D.; et al. Correction of human phospholamban R14del mutation associated with cardiomyopathy using targeted nucleases and combination therapy. Nat. Commun. 2015, 6, 6955. [CrossRef]

438. Stillitano, F.; Turnbull, I.C.; Karakikes, I.; Nonnenmacher, M.; Backeris, P.; Hulot, J.S.; Kranias, E.G.; Hajjar, R.J.; Costa, K.D. Genomic correction of familial cardiomyopathy in human engineered cardiac tissues. Eur. Heart J. 2016, 37, 3282-3284. [CrossRef]

439. Ben Jehuda, R.; Eisen, B.; Shemer, Y.; Mekies, L.N.; Szantai, A.; Reiter, I.; Cui, H.; Guan, K.; Haron-Khun, S.; Freimark, D.; et al. CRISPR correction of the PRKAG2 gene mutation in the patient's induced pluripotent stem cell-derived cardiomyocytes eliminates electrophysiological and structural abnormalities. Heart Rhythm 2018, 15, 267-276. [CrossRef]

440. Hinson, J.T.; Chopra, A.; Lowe, A.; Sheng, C.C.; Gupta, R.M.; Kuppusamy, R.; O'Sullivan, J.; Rowe, G.; Wakimoto, H.; Gorham, J.; et al. Integrative analysis of PRKAG2 cardiomyopathy iPS and microtissue models identifies AMPK as a regulator of metabolism, survival, and fibrosis. Cell Rep. 2017, 19, 2410. [CrossRef]

441. Li, R.; Baskfield, A.; Lin, Y.; Beers, J.; Zou, J.; Liu, C.; Jaffre, F.; Roberts, A.E.; Ottinger, E.A.; Kontaridis, M.I.; et al. Generation of an induced pluripotent stem cell line (TRNDi003-A) from a Noonan syndrome with multiple lentigines (NSML) patient carrying a p.Q510P mutation in the PTPN11 gene. Stem Cell Res. 2019, 34, 101374. [CrossRef] [PubMed]

442. Jaffre, F.; Miller, C.L.; Schanzer, A.; Evans, T.; Roberts, A.E.; Hahn, A.; Kontaridis, M.I. iPSC-derived cardiomyocytes reveal aberrant ERK5 and MEK1/2 signaling concomitantly promote hypertrophic cardiomyopathy in RAF1-associated noonan syndrome. Circulation 2019, 140, 207-224. [CrossRef] [PubMed]

443. Streckfuss-Bomeke, K.; Tiburcy, M.; Fomin, A.; Luo, X.; Li, W.; Fischer, C.; Ozcelik, C.; Perrot, A.; Sossalla, S.; Haas, J.; et al. Severe DCM phenotype of patient harboring RBM20 mutation S635A can be modeled by patient-specific induced pluripotent stem cell-derived cardiomyocytes. J. Mol. Cell. Cardiol. 2017, 113, 9-21. [CrossRef] [PubMed]

444. Wyles, S.P.; Li, X.; Hrstka, S.C.; Reyes, S.; Oommen, S.; Beraldi, R.; Edwards, J.; Terzic, A.; Olson, T.M.; Nelson, T.J. Modeling structural and functional deficiencies of RBM20 familial dilated cardiomyopathy using human induced pluripotent stem cells. Hum. Mol. Genet. 2016, 25, 254-265. [CrossRef]

445. Wyles, S.P.; Hrstka, S.C.; Reyes, S.; Terzic, A.; Olson, T.M.; Nelson, T.J. Pharmacological modulation of calcium homeostasis in familial dilated cardiomyopathy: An in vitro analysis from an RBM20 patient-derived iPSC model. Clin. Transl. Sci. 2016, 9, 158-167. [CrossRef] [PubMed] 
446. Te Riele, A.S.; Agullo-Pascual, E.; James, C.A.; Leo-Macias, A.; Cerrone, M.; Zhang, M.; Lin, X.; Lin, B.; Sobreira, N.L.; Amat-Alarcon, N.; et al. Multilevel analyses of SCN5A mutations in arrhythmogenic right ventricular dysplasia/cardiomyopathy suggest non-canonical mechanisms for disease pathogenesis. Cardiovasc. Res. 2017, 113, 102-111. [CrossRef]

447. Moreau, A.; Gosselin-Badaroudine, P.; Mercier, A.; Burger, B.; Keller, D.I.; Chahine, M. A leaky voltage sensor domain of cardiac sodium channels causes arrhythmias associated with dilated cardiomyopathy. Sci. Rep. 2018, 8, 13804. [CrossRef]

448. Hallas, T.; Eisen, B.; Shemer, Y.; Ben Jehuda, R.; Mekies, L.N.; Naor, S.; Schick, R.; Eliyahu, S.; Reiter, I.; Vlodavsky, E.; et al. Investigating the cardiac pathology of SCO2-mediated hypertrophic cardiomyopathy using patients induced pluripotent stem cell-derived cardiomyocytes. J. Cell. Mol. Med. 2018, 22, 913-925. [CrossRef]

449. Wang, G.; McCain, M.L.; Yang, L.; He, A.; Pasqualini, F.S.; Agarwal, A.; Yuan, H.; Jiang, D.; Zhang, D.; Zangi, L.; et al. Modeling the mitochondrial cardiomyopathy of Barth syndrome with induced pluripotent stem cell and heart-on-chip technologies. Nat. Med. 2014, 20, 616-623. [CrossRef]

450. Kodo, K.; Ong, S.G.; Jahanbani, F.; Termglinchan, V.; Hirono, K.; InanlooRahatloo, K.; Ebert, A.D.; Shukla, P.; Abilez, O.J.; Churko, J.M.; et al. iPSC-derived cardiomyocytes reveal abnormal TGF- $\beta$ signalling in left ventricular non-compaction cardiomyopathy. Nat. Cell Biol. 2016, 18, 1031-1042. [CrossRef]

451. Sun, N.; Yazawa, M.; Liu, J.; Han, L.; Sanchez-Freire, V.; Abilez, O.J.; Navarrete, E.G.; Hu, S.; Wang, L.; Lee, A.; et al. Patient-specific induced pluripotent stem cells as a model for familial dilated cardiomyopathy. Sci. Transl. Med. 2012, 4, 130ra47. [CrossRef] [PubMed]

452. Wu, H.; Lee, J.; Vincent, L.G.; Wang, Q.; Gu, M.; Lan, F.; Churko, J.M.; Sallam, K.I.; Matsa, E.; Sharma, A.; et al. Epigenetic regulation of phosphodiesterases $2 \mathrm{~A}$ and $3 \mathrm{~A}$ underlies compromised $\beta$-adrenergic signaling in an iPSC model of dilated cardiomyopathy. Cell Stem Cell 2015, 17, 89-100. [CrossRef] [PubMed]

453. Karakikes, I.; Termglinchan, V.; Cepeda, D.A.; Lee, J.; Diecke, S.; Hendel, A.; Itzhaki, I.; Ameen, M.; Shrestha, R.; Wu, H.; et al. A comprehensive TALEN-based knockout library for generating human-induced pluripotent stem cell-based models for cardiovascular diseases. Circ. Res. 2017, 120, 1561-1571. [CrossRef] [PubMed]

454. Broughton, K.M.; Li, J.; Sarmah, E.; Warren, C.M.; Lin, Y.H.; Henze, M.P.; Sanchez-Freire, V.; Solaro, R.J.; Russell, B. A myosin activator improves actin assembly and sarcomere function of human-induced pluripotent stem cell-derived cardiomyocytes with a troponin T point mutation. Am. J. Physiol. Heart Circ. Physiol. 2016, 311, H107-H117. [CrossRef] [PubMed]

455. Wang, L.; Kryshtal, D.O.; Kim, K.; Parikh, S.; Cadar, A.G.; Bersell, K.R.; He, H.; Pinto, J.R.; Knollmann, B.C. Myofilament calcium-buffering dependent action potential triangulation in human-induced pluripotent stem cell model of hypertrophic cardiomyopathy. J. Am. Coll. Cardiol. 2017, 70, 2600-2602. [CrossRef] [PubMed]

456. Wang, L.; Kim, K.; Parikh, S.; Cadar, A.G.; Bersell, K.R.; He, H.; Pinto, J.R.; Kryshtal, D.O.; Knollmann, B.C. Hypertrophic cardiomyopathy-linked mutation in troponin T causes myofibrillar disarray and pro-arrhythmic action potential changes in human iPSC cardiomyocytes. J. Mol. Cell. Cardiol. 2018, 114, 320-327. [CrossRef] [PubMed]

457. Hinson, J.T.; Chopra, A.; Nafissi, N.; Polacheck, W.J.; Benson, C.C.; Swist, S.; Gorham, J.; Yang, L.; Schafer, S.; Sheng, C.C.; et al. Titin mutations in iPS cells define sarcomere insufficiency as a cause of dilated cardiomyopathy. Science 2015, 349, 982-986. [CrossRef] [PubMed]

458. Schick, R.; Mekies, L.N.; Shemer, Y.; Eisen, B.; Hallas, T.; Ben Jehuda, R.; Ben-Ari, M.; Szantai, A.; Willi, L.; Shulman, R.; et al. Functional abnormalities in induced pluripotent stem cell-derived cardiomyocytes generated from titin-mutated patients with dilated cardiomyopathy. PLoS ONE 2018, 13, e0205719. [CrossRef] [PubMed]

459. Leung, A.; Nah, S.K.; Reid, W.; Ebata, A.; Koch, C.M.; Monti, S.; Genereux, J.C.; Wiseman, R.L.; Wolozin, B.; Connors, L.H.; et al. Induced pluripotent stem cell modeling of multisystemic, hereditary transthyretin amyloidosis. Stem Cell Rep. 2013, 1, 451-463. [CrossRef]

460. Pinto, A.R.; Ilinykh, A.; Ivey, M.J.; Kuwabara, J.T.; D'Antoni, M.L.; Debuque, R.; Chandran, A.; Wang, L.; Arora, K.; Rosenthal, N.A.; et al. Revisiting cardiac cellular composition. Circ. Res. 2016, 118, 400-409. [CrossRef] 
461. Castro, L.; Geertz, B.; Reinsch, M.; Aksehirlioglu, B.; Hansen, A.; Eschenhagen, T.; Reichenspurner, H.; Weinberger, F.; Pecha, S. Implantation of hiPSC-derived cardiac-muscle patches after myocardial injury in a Guinea pig model. J. Vis. Exp. 2019, 145, e58810. [CrossRef] [PubMed]

462. Lemoine, M.D.; Mannhardt, I.; Breckwoldt, K.; Prondzynski, M.; Flenner, F.; Ulmer, B.; Hirt, M.N.; Neuber, C.; Horvath, A.; Kloth, B.; et al. Human iPSC-derived cardiomyocytes cultured in 3D engineered heart tissue show physiological upstroke velocity and sodium current density. Sci. Rep. 2017, 7, 5464. [CrossRef] [PubMed]

463. Breckwoldt, K.; Letuffe-Breniere, D.; Mannhardt, I.; Schulze, T.; Ulmer, B.; Werner, T.; Benzin, A.; Klampe, B.; Reinsch, M.C.; Laufer, S.; et al. Differentiation of cardiomyocytes and generation of human engineered heart tissue. Nat. Protoc. 2017, 12, 1177-1197. [CrossRef] [PubMed]

464. Weinberger, F.; Mannhardt, I.; Eschenhagen, T. Engineering cardiac muscle tissue: A maturating field of research. Circ. Res. 2017, 120, 1487-1500. [CrossRef] [PubMed]

465. Meyer, T.; Tiburcy, M.; Zimmermann, W.H. Cardiac macrotissues-on-a-plate models for phenotypic drug screens. Adv. Drug Deliv. Rev. 2019, 140, 93-100. [CrossRef] [PubMed]

466. Garber, K. RIKEN suspends first clinical trial involving induced pluripotent stem cells. Nat. Biotechnol. 2015, 33, 890-891. [CrossRef] [PubMed]

467. Mayshar, Y.; Ben-David, U.; Lavon, N.; Biancotti, J.C.; Yakir, B.; Clark, A.T.; Plath, K.; Lowry, W.E.; Benvenisty, N. Identification and classification of chromosomal aberrations in human induced pluripotent stem cells. Cell Stem Cell 2010, 7, 521-531. [CrossRef] [PubMed]

468. Yoshihara, M.; Hayashizaki, Y.; Murakawa, Y. Genomic instability of iPSCs: Challenges towards their clinical applications. Stem Cell Rev. 2017, 13, 7-16. [CrossRef]

469. Liu, P.; Kaplan, A.; Yuan, B.; Hanna, J.H.; Lupski, J.R.; Reiner, O. Passage number is a major contributor to genomic structural variations in mouse iPSCs. Stem Cells 2014, 32, 2657-2667. [CrossRef]

470. Kempf, H.; Zweigerdt, R. Scalable cardiac differentiation of pluripotent stem cells using specific growth factors and small molecules. In Engineering and Application of Pluripotent Stem Cells; Springer: Cham, Switzerland, 2017; Volume 163, pp. 39-69.

471. Goktepe, S.; Abilez, O.J.; Parker, K.K.; Kuhl, E. A multiscale model for eccentric and concentric cardiac growth through sarcomerogenesis. J. Theor. Biol. 2010, 265, 433-442. [CrossRef]

472. Gherghiceanu, M.; Barad, L.; Novak, A.; Reiter, I.; Itskovitz-Eldor, J.; Binah, O.; Popescu, L.M. Cardiomyocytes derived from human embryonic and induced pluripotent stem cells: Comparative ultrastructure. J. Cell. Mol. Med. 2011, 15, 2539-2551. [CrossRef] [PubMed]

473. Jiang, Y.; Park, P.; Hong, S.M.; Ban, K. Maturation of cardiomyocytes derived from human pluripotent stem cells: Current strategies and limitations. Mol. Cells 2018, 41, 613-621. [PubMed]

474. Koivumaki, J.T.; Naumenko, N.; Tuomainen, T.; Takalo, J.; Oksanen, M.; Puttonen, K.A.; Lehtonen, S.; Kuusisto, J.; Laakso, M.; Koistinaho, J.; et al. Structural immaturity of human iPSC-derived cardiomyocytes: In silico investigation of effects on function and disease modeling. Front. Physiol. 2018, 9, 80. [CrossRef]

475. Bedada, F.B.; Wheelwright, M.; Metzger, J.M. Maturation status of sarcomere structure and function in human iPSC-derived cardiac myocytes. Biochim. Biophys. Acta 2016, 1863, 1829-1838. [CrossRef] [PubMed]

476. Vermij, S.H.; Abriel, H.; van Veen, T.A. Refining the molecular organization of the cardiac intercalated disc. Cardiovasc. Res. 2017, 113, 259-275. [CrossRef] [PubMed]

477. Fujiwara, M.; Yan, P.; Otsuji, T.G.; Narazaki, G.; Uosaki, H.; Fukushima, H.; Kuwahara, K.; Harada, M.; Matsuda, H.; Matsuoka, S.; et al. Induction and enhancement of cardiac cell differentiation from mouse and human induced pluripotent stem cells with cyclosporin-A. PLoS ONE 2011, 6, e16734. [CrossRef]

478. Zuppinger, C.; Gibbons, G.; Dutta-Passecker, P.; Segiser, A.; Most, H.; Suter, T.M. Characterization of cytoskeleton features and maturation status of cultured human iPSC-derived cardiomyocytes. Eur. J. Histochem. 2017, 61, 2763. [CrossRef]

479. Scuderi, G.J.; Butcher, J. Naturally engineered maturation of cardiomyocytes. Front. Cell Dev. Biol. 2017, 5, 50. [CrossRef]

480. Brodsky, V.; Chernyaev, A.L.; Vasilyeva, I.A. Variability of the cardiomyocyte ploidy in normal human hearts. Virchows Archiv. B 1991, 61, 289-294. [CrossRef]

481. Feric, N.T.; Radisic, M. Maturing human pluripotent stem cell-derived cardiomyocytes in human engineered cardiac tissues. Adv. Drug Deliv. Rev. 2016, 96, 110-134. [CrossRef] 
482. Veerman, C.C.; Kosmidis, G.; Mummery, C.L.; Casini, S.; Verkerk, A.O.; Bellin, M. Immaturity of human stem-cell-derived cardiomyocytes in culture: Fatal flaw or soluble problem? Stem Cells Dev. 2015, 24, 1035-1052. [CrossRef] [PubMed]

483. Nguyen, M.D.; Tinney, J.P.; Ye, F.; Elnakib, A.A.; Yuan, F.; El-Baz, A.; Sethu, P.; Keller, B.B.; Giridharan, G.A. Effects of physiologic mechanical stimulation on embryonic chick cardiomyocytes using a microfluidic cardiac cell culture model. Anal. Chem. 2015, 87, 2107-2113. [CrossRef] [PubMed]

484. Sarig, U.; Sarig, H.; de-Berardinis, E.; Chaw, S.Y.; Nguyen, E.B.; Ramanujam, V.S.; Thang, V.D.; Al-Haddawi, M.; Liao, S.; Seliktar, D.; et al. Natural myocardial ECM patch drives cardiac progenitor based restoration even after scarring. Acta Biomater. 2016, 44, 209-220. [CrossRef] [PubMed]

485. Chen, W.C.; Wang, Z.; Missinato, M.A.; Park, D.W.; Long, D.W.; Liu, H.J.; Zeng, X.; Yates, N.A.; Kim, K.; Wang, Y. Decellularized zebrafish cardiac extracellular matrix induces mammalian heart regeneration. Sci. Adv. 2016, 2, e1600844. [CrossRef] [PubMed]

486. Kim, C.; Majdi, M.; Xia, P.; Wei, K.A.; Talantova, M.; Spiering, S.; Nelson, B.; Mercola, M.; Chen, H.S. Non-cardiomyocytes influence the electrophysiological maturation of human embryonic stem cell-derived cardiomyocytes during differentiation. Stem Cells Dev. 2010, 19, 783-795. [CrossRef] [PubMed]

487. Kolanowski, T.J.; Antos, C.L.; Guan, K. Making human cardiomyocytes up to date: Derivation, maturation state and perspectives. Int. J. Cardiol. 2017, 241, 379-386. [CrossRef] [PubMed]

488. Glazier, A.A.; Thompson, A.; Day, S.M. Allelic imbalance and haploinsufficiency in MYBPC3-linked hypertrophic cardiomyopathy. Pflugers Archiv Eur. J. Physiol. 2019, 471, 781-793. [CrossRef] [PubMed]

489. Clemen, C.S.; Stockigt, F.; Strucksberg, K.H.; Chevessier, F.; Winter, L.; Schutz, J.; Bauer, R.; Thorweihe, J.M.; Wenzel, D.; Schlotzer-Schrehardt, U.; et al. The toxic effect of R350P mutant desmin in striated muscle of man and mouse. Acta Neuropathol. 2015, 129, 297-315. [CrossRef]

490. Sugawara, M.; Kato, K.; Komatsu, M.; Wada, C.; Kawamura, K.; Shindo, P.S.; Yoshioka, P.N.; Tanaka, K.; Watanabe, S.; Toyoshima, I. A novel de novo mutation in the desmin gene causes desmin myopathy with toxic aggregates. Neurology 2000, 55, 986-990. [CrossRef] [PubMed]

491. Ma, H.; Marti-Gutierrez, N.; Park, S.W.; Wu, J.; Lee, Y.; Suzuki, K.; Koski, A.; Ji, D.; Hayama, T.; Ahmed, R.; et al. Correction of a pathogenic gene mutation in human embryos. Nature 2017, 548, 413-419. [CrossRef]

492. Echigoya, Y.; Lim, K.R.Q.; Nakamura, A.; Yokota, T. Multiple Exon skipping in the duchenne muscular dystrophy hot spots: Prospects and challenges. J. Personal. Med. 2018, 8, 41. [CrossRef] [PubMed]

493. Aartsma-Rus, A.; van Ommen, G.J. Antisense-mediated exon skipping: A versatile tool with therapeutic and research applications. Rna 2007, 13, 1609-1624. [CrossRef] [PubMed]

494. Dick, E.; Kalra, S.; Anderson, D.; George, V.; Ritso, M.; Laval, S.H.; Barresi, R.; Aartsma-Rus, A.; Lochmuller, H.; Denning, C. Exon skipping and gene transfer restore dystrophin expression in human induced pluripotent stem cells-cardiomyocytes harboring DMD mutations. Stem Cells Dev. 2013, 22, 2714-2724. [CrossRef] [PubMed]

495. Van Deutekom, J.C.; Janson, A.A.; Ginjaar, I.B.; Frankhuizen, W.S.; Aartsma-Rus, A.; Bremmer-Bout, M.; den Dunnen, J.T.; Koop, K.; van der Kooi, A.J.; Goemans, N.M.; et al. Local dystrophin restoration with antisense oligonucleotide PRO051. N. Engl. J. Med. 2007, 357, 2677-2686. [CrossRef] [PubMed]

496. Zhang, Y.; Long, C.; Li, H.; McAnally, J.R.; Baskin, K.K.; Shelton, J.M.; Bassel-Duby, R.; Olson, E.N. CRISPR-Cpf1 correction of muscular dystrophy mutations in human cardiomyocytes and mice. Sci. Adv. 2017, 3, e1602814. [CrossRef] [PubMed]

497. Min, Y.L.; Li, H.; Rodriguez-Caycedo, C.; Mireault, A.A.; Huang, J.; Shelton, J.M.; McAnally, J.R.; Amoasii, L.; Mammen, P.P.A.; Bassel-Duby, R.; et al. CRISPR-Cas9 corrects Duchenne muscular dystrophy exon 44 deletion mutations in mice and human cells. Sci. Adv. 2019, 5, eaav4324. [CrossRef] [PubMed]

498. White, J.A.; McAlpine, P.J.; Antonarakis, S.; Cann, H.; Eppig, J.T.; Frazer, K.; Frezal, J.; Lancet, D.; Nahmias, J.; Pearson, P.; et al. Guidelines for human gene nomenclature (1997). HUGO nomenclature committee. Genomics 1997, 45, 468-471. [CrossRef] [PubMed]

(C) 2019 by the authors. Licensee MDPI, Basel, Switzerland. This article is an open access article distributed under the terms and conditions of the Creative Commons Attribution (CC BY) license (http://creativecommons.org/licenses/by/4.0/). 